\title{
The petrologic and degassing behavior of sulfur and other magmatic volatiles from the 2018 eruption of Kilauea, Hawai'i: melt concentrations, magma storage depths, and magma recycling
}

\author{
Allan H. Lerner ${ }^{1,2}$ (D) Paul J. Wallace ${ }^{1} \cdot$ Thomas Shea $^{3} \cdot$ Adrien J. Mourey $^{3} \cdot$ Peter J. Kelly $^{4} \cdot$ Patricia A. Nadeau $^{5}$. \\ Tamar Elias $^{5} \cdot$ Christoph Kern $^{4} \cdot$ Laura E. Clor $^{4} \cdot$ Cheryl Gansecki $^{6} \cdot$ R. Lopaka Lee Lowell R. Moore $^{7} \cdot$ Cynthia A. Werner $^{8}$
}

Received: 7 October 2020 / Accepted: 13 April 2021 / Published online: 3 June 2021

(C) This is a U.S. government work and not under copyright protection in the U.S.; foreign copyright protection may apply 2021

\begin{abstract}
Kīlauea Volcano's 2018 lower East Rift Zone (LERZ) eruption produced exceptionally high lava effusion rates and record-setting $\mathrm{SO}_{2}$ emissions. The eruption involved a diverse range of magmas, including primitive basalts sourced from Kilauea's summit reservoirs. We analyzed LERZ matrix glasses, melt inclusions, and host minerals to identify melt volatile contents and magma storage depths. The LERZ glasses and melt inclusions span nearly the entire compositional range previously recognized at Kilauea. Melt inclusions in $\mathrm{Fo}_{86-89}$ olivine from the main eruptive vent (fissure 8) underwent $70-170^{\circ} \mathrm{C}$ cooling during transport in LERZ carrier melts, causing extensive post-entrapment crystallization and sulfide precipitation. Many of these melt inclusions have low sulfur (400-900 ppm) even after correction for sulfide formation. $\mathrm{CO}_{2}$ and $\mathrm{H}_{2} \mathrm{O}$ vapor saturation pressures indicate shallow melt inclusion trapping depths ( $\left.1-5 \mathrm{~km}\right)$, consistent with formation within Kïlauea's Halema uma $u$ and South Caldera reservoirs. Many of these inclusions also have degassed $\delta^{34} \mathrm{~S}$ values $(-1.5$ to $-0.5 \%$ ) . Collectively, these results indicate that some primitive melts experienced near-surface degassing before being trapped into melt inclusions. We propose that decades-to-centuries of repeated lava lake activity and lava drain-back during eruptions (e.g., 1959 Kïlauea Iki) recycled substantial volumes of degassed magma into Kilauea's shallow reservoir system. Degassing and magma recycling from the 2008-2018 Halema'uma'u lava lake likely reduced the volatile contents of LERZ fissure 8 magmas, resulting in lower fountain heights compared to many prior Kilauea eruptions. The eruption's extreme $\mathrm{SO}_{2}$ emissions were due to high lava effusion rates rather than particularly volatile-rich melts.
\end{abstract}

Keywords Degassing $\cdot$ Melt inclusions $\cdot$ Sulfur budget $\cdot \delta^{34} \mathrm{~S} \cdot$ Magma recycling $\cdot$ Kīlauea Volcano

Editorial responsibility: M.R. Patrick

This paper constitutes part of a topical collection:

The historic events at Kilauea Volcano in 2018: summit collapse, rift zone eruption, and Mw6.9 earthquake

$\triangle$ Allan H. Lerner

alerner@uoregon.edu

1 University of Oregon, Eugene, OR 97403, USA

2 Present Address: U.S. Geological Survey Cascades Volcano Observatory, Vancouver, WA 98683, USA

3 University of Hawai' i-Mānoa, Honolulu, HI 96822, USA

4 U.S. Geological Survey Cascades Volcano Observatory, Vancouver, WA 98683, USA

5 U.S. Geological Survey Hawaiian Volcano Observatory, Hilo, HI 96720, USA

6 University of Hawai' $\mathrm{i}$-Hilo, Hilo, HI 96720, USA

7 Virginia Tech, Blacksburg, VA 24061, USA

8 U.S. Geological Survey (Contractor), New Plymouth, New Zealand

\section{Introduction}

The 2018 lower East Rift Zone (LERZ) eruption of Kīlauea Volcano (Hawai'i, USA) provides a notable example of how multidisciplinary eruption monitoring coupled with detailed geochemistry can revise our understanding of volcanic processes at Kīlauea (Gansecki et al. 2019; Neal et al. 2019). The 2018 LERZ fissure eruption was one of Kīlauea's largest eruptions in $>200$ years and was well monitored and sampled by the U.S. Geological Survey's Hawaiian Volcano Observatory (USGSHVO) (Anderson et al. 2019; Gansecki et al. 2019; Neal et al. 2019; Patrick et al. 2019c, 2020b; Kern et al. 2020; Shiro et al. 2021; Dietterich et al. 2021). Between May and August, fissures in the LERZ erupted 0.9 to $\geq 1.4 \mathrm{~km}^{3}$ of dense rock equivalent (DRE) lava (Kern et al. 2020; Dietterich et al. 2021) and were accompanied by record-setting $\mathrm{SO}_{2}$ gas emissions (Kern et al. 2020) and a major summit caldera collapse (Anderson et al. 2019). 
Prior to the LERZ eruption, a remarkable dual-vent eruption had been occurring at Kîlauea (Patrick et al. 2019b). The Pu' $u^{\prime} \bar{o}^{`}$ ō vent had been erupting on Kīlauea's East Rift Zone (ERZ) since 1983, and a lava lake began forming within the Halema'uma'u summit crater in 2008 (Patrick et al. 2021). From 2008 to 2018, magma ascending at the volcano's summit convectively degassed in the lava lake, then sank and became partially hybridized with stored summit and ERZ magmas while traveling $\sim 20 \mathrm{~km}$ down-rift to erupt at $\mathrm{Pu}^{\text {' }} \mathrm{u}^{`} \mathrm{o}^{`}$ 'o (e.g., Elias and Sutton 2012; Edmonds et al. 2013; Orr et al. 2015; Thornber et al. 2015; Patrick et al. 2019b).

In early 2018, both $\mathrm{Pu}^{\prime} \mathrm{u}^{\prime} \bar{o}^{‘} \bar{o}$ and Kōlauea's summit began pressurizing, and on April 30, a dike propagated from beneath $\mathrm{Pu}^{\prime} \mathrm{u}^{`} \mathrm{o}^{`}{ }^{`} \mathrm{o}$ toward the LERZ (Neal et al. 2019; Montgomery-Brown et al. 2020; Patrick et al. 2020b). On May 3, the first of 24 fissures erupted within the LERZ (Patrick et al. 2020a). Early erupted lavas (phase 1) were mostly evolved basalts, although a small volume of unusual andesite erupted more explosively from fissure 17 (Gansecki et al. 2019). Hotter, more primitive "summitlike" lavas began erupting on May 17-18 (phase 2), and lava effusion rates increased substantially (Gansecki et al. 2019; Neal et al. 2019). On May 27-28, activity focused at fissure 8 (formally named Ahu'ailā'au), which became the dominant vent for the remainder of the eruption (phase 3) (Neal et al. 2019). Fissure 8 produced lava fountains with maximum heights of $50-80 \mathrm{~m}$, and fed a fast-flowing lava channel that eventually traveled $>10 \mathrm{~km}$ to the ocean (Neal et al. 2019; Patrick et al. 2019c). High lava effusion rates in the LERZ were accompanied by draining of the summit lava lake and rhythmic collapse of the summit caldera as magma was emptied from the summit reservoirs (Anderson et al. 2019). As the evacuated Halema'uma'u lava lake conduit became filled with collapse debris, $\mathrm{SO}_{2}$ degassing rates at the summit decreased from a decade-long average of $\sim 4.5$ kilotons per day (kt/day) to $\sim 1 \mathrm{kt} / \mathrm{day}$ by June, and $\mathrm{SO}_{2}$ emissions were near instrument detection limits $(\leq 0.05 \mathrm{kt} /$ day) by September (Kern et al. 2020). On August 2, the summit collapses abruptly ceased, and the LERZ eruptive activity sharply declined on August 4-5. The large volume of magma erupted from LERZ fissures amounts to $>10$ years' worth of Kîlauea's average magma supply being erupted within three months (Poland et al. 2014; Anderson and Poland 2017; Dietterich et al. 2021).

The LERZ fissures produced hazardous lava flows and prodigious gas emissions that profoundly impacted communities in the district of Puna. Sustained $\mathrm{SO}_{2}$ emission rates of $>100 \mathrm{kt} /$ day during phase 3 activity at fissure 8 (F8) amounted to a 20-fold increase in total $\mathrm{SO}_{2}$ emissions from Kīlauea (Elias and Sutton 2012; Sutton and Elias 2014; Elias et al. 2020; Kern et al. 2020). Understanding the factors that contributed to this remarkable $\mathrm{SO}_{2}$ output is important for constraining the eruption's lava and sulfur (S) budgets (Sutton et al. 2003; Kern et al. 2020; Dietterich et al. 2021), and for improving our ability to anticipate and interpret future degassing activity and associated hazards.

Here, we combine compositional, redox, isotopic, and volatile measurements of matrix glasses, melt inclusions (MI), and their mineral hosts from Kîlauea's 2018 LERZ eruption to provide insights into magma reservoir processes and volatile behavior during ascent and lava emplacement. Our results show that sulfur concentrations in LERZ materials are highly variable due to pre-eruptive degassing, magma mixing, and sulfide saturation, and that many primitive MI were affected by extreme post-entrapment crystallization due to magma mixing. Using an updated H-C-S degassing model for Kīlauea, we interpret magma degassing behavior and the effects of $\mathrm{SO}_{2}$ degassing on sulfur-isotope fractionation. $\mathrm{H}_{2} \mathrm{O}-\mathrm{CO}_{2}$ measurements in $\mathrm{MI}$ indicate that LERZ phase 3 magmas were sourced from relatively shallow depths. Collectively, our observations suggest that the recycling of shallowly degassed magma is an important process at Kīlauea.

\section{Methods}

We investigated rapidly cooled lava samples collected by USGS-HVO teams throughout the LERZ eruption (Gansecki et al. 2019; Lee et al. 2019). Samples include water-quenched molten samples from the active lava channel $(n=4)$, naturally quenched spatter and basaltic pumice from eruptive fissures $(n=3)$, and naturally quenched tephra from an explosive ocean entry littoral blast $(n=1)$ (Table 1, Figs. 1 and S1). These samples all contain matrix glass and glassy MI. We also sampled an air-cooled lava clast from the final lava channel overflow of F8 (LF8, erupted $\sim$ August 4, 2018). The groundmass of this sample is mostly crystallized and large MI are devitrified; however, smaller MI $(\leq 50 \mu \mathrm{m}$ diameter $)$ remain glassy. A subset of large devitrified MI from LF8 were rehomogenized at $1200-1300{ }^{\circ} \mathrm{C}$ prior to analysis.

Phenocrysts were individually mounted and singly or doubly polished to expose glassy MI and re-entrant melt channels (RE) (Figs. 2 and S2) . Interstitial melts (glass regions partially bounded by surrounding crystals) were similarly exposed by polishing mounted crystal clusters. Matrix glass was commonly preserved around crystal edges. Polished thin sections and multi-grain mounts were also made from a subset of samples, with a number of MI intersected by random sectioning. Major element compositions of glasses (matrix glass, MI, RE) and minerals were analyzed by electron probe micro-analyzer (EPMA). Water and $\mathrm{CO}_{2}$ concentrations of glasses were measured by Fourier transform infrared spectroscopy (FTIR), and 
Table 1 Major chronological events of the 2018 Kīlauea LERZ eruption (italicized rows) and eruption details of samples analyzed in this study

\begin{tabular}{|c|c|c|}
\hline Sample name (fissure source) or chronological event & Eruption or event date & Sample description or event reference \\
\hline First LERZ eruptive fissures & May 3, 2018 & Neal et al. (2019) \\
\hline KE62-3394S (fissure 9) & May 5-6, 2018 & Rapidly cooled spatter \\
\hline KE62-3256S (fissure 17) & May 18, 2018 & Rapidly cooled spatter \\
\hline Eruption of hotter summit/Pu' $u^{\varsigma} \bar{o}^{\varsigma} \bar{o}$-like lavas & May 18,2018 & Gansecki et al. (2019); Neal et al. (2019) \\
\hline First ocean entries & May 19, 2018 & Gansecki et al. (2019); Neal et al. (2019) \\
\hline Lava effusion focuses at re-activated fissure 8 & May 27-28, 2018 & Gansecki et al. (2019); Neal et al. (2019) \\
\hline KE62-3293S (fissure 8) & May 28-30, 2018 & Naturally air-quenched, freshly fallen basaltic pumice \\
\hline KE62-3314F (fissure 8) & July 14, 2018 & Water-quenched sample from lava channel \\
\hline KE62-3315F (fissure 8) & July 15-16, 2018 & $\begin{array}{l}\text { Naturally air-/water-quenched tephra debris from tour } \\
\text { boat struck by littoral blast bomb(s) offshore of } \\
\text { ocean entry }\end{array}$ \\
\hline KE62-3316F (fissure 8) & July 20, 2018 & Water-quenched sample from lava channel \\
\hline KE62-3321F (fissure 8) & August 1, 2018 & Water-quenched sample from lava channel \\
\hline LF8 (fissure 8) & August 4, 2018 & $\begin{array}{l}\text { Naturally cooled vesicular lava with glassy rind from } \\
\text { the last lava channel overflow, collected next to } \\
\text { channel rim }\end{array}$ \\
\hline KE62-3323F (fissure 8) & $\sim$ August 4-5, 2018 & Water-quenched sample from 'a 'a flow front \\
\hline End of major lava effusion & August 5, 2018 & Gansecki et al. (2019); Neal et al. (2019) \\
\hline End of eruption (last visible surface lava) & September 5, 2018 & Neal et al. (2019) \\
\hline
\end{tabular}

$\mathrm{CO}_{2}$ sequestered in $\mathrm{MI}$ vapor bubbles was determined by Raman spectroscopy. Sulfur isotopes $\left(\delta^{34} \mathrm{~S}\right)$ in matrix glasses and MI were measured by secondary ion mass spectrometry (SIMS). Post entrapment crystallization (PEC) and Fe-diffusive loss in olivine-hosted MI were corrected using Petrolog3 (Danyushevsky and Plechov 2011). Melt inclusions are PECrestored to $11.5 \mathrm{wt} \%$ total iron $\left(\mathrm{FeO}^{\mathrm{T}}\right)$ based on the Kilauea whole-rock and glass $\mathrm{FeO}^{\mathrm{T}}$ array (Fig. S5). Petrolog3 corrections were done at a fixed oxygen fugacity $\left(\mathrm{O}_{2}\right)$ of FMQ +0.25 (Lerner 2020) using the olivine-melt exchange model of Beattie (1993), which resulted in a melt-olivine $\mathrm{Kd}_{\mathrm{Fe}-\mathrm{Mg}}$ of $\sim 0.32$ for MI restorations. Sulfide globules are present in a number of $\mathrm{MI}$ in $\mathrm{Fo}_{83-89}$ olivine (where $\mathrm{Fo}=100 * \mathrm{Mg} /[\mathrm{Mg}+\mathrm{Fe}]$ in molar fractions), and "sulfide-restored" sulfur concentrations for these MI were calculated by mass balance. See the Supplementary Materials for a complete description of analytical procedures and applied corrections.

\section{Results}

\section{Petrography and compositions of minerals and matrix glasses}

Minerals and melts erupted from the Kīlauea LERZ fissures are compositionally and texturally diverse (Fig. S1). Our study focuses primarily on erupted material from F8 during phase 3 of activity, which produced $90-94 \%$ of the total eruption volume (Dietterich et al. 2021). Magmas from the F8 lava channel become slightly more Mg-rich through the course of the eruption (Gansecki et al. 2019), with glass-Mg eruption temperatures increasing from $\sim 1140{ }^{\circ} \mathrm{C}$ in late May to $\sim 1150{ }^{\circ} \mathrm{C}$ in August, corresponding to equilibrium olivine compositions of $\mathrm{Fo}_{78}$ to $\mathrm{Fo}_{80}$ (Fig. 3). Consistent with Gansecki et al. (2019), Mourey et al. (2019), and Wieser et al. (2021), we observe a diverse range of crystal cargo in phase 3 lavas, including both primitive and evolved olivine $\left(\mathrm{Fo}_{76-89}, n=148\right)$, as well as plagioclase, clinopyroxene, and minor orthopyroxene. Low-Fo olivine phenocrysts are unzoned and have compositions $\left(\mathrm{Fo}_{76-80}\right)$ that match $\mathrm{F} 8$ groundmass olivine and calculated matrix glass equilibrium-olivine compositions, indicating that they likely formed within the F8 carrier melt. High-Fo olivine grains $\left(\mathrm{Fo}_{86-89}\right)$ have 5-250 $\mu \mathrm{m}$ thick lower $\mathrm{Mg}$-rims $\left(\mathrm{Fo}_{76-81}\right)$ (Gansecki et al. 2019; this study) (Figs. 2 and S2), typically representing weeks to months of disequilibrium residence of high-Fo olivine within a cooler melt (Mourey et al. 2019).

Early F8 lava fountaining at the onset of phase 3 produced abundant rapidly quenched basaltic pumice (Fig. S1d, e). Pumice clasts were air-quenched within seconds of eruption and thus record melt and volatile behavior during ascent and eruption without complications from post-eruptive processes occurring in lava flows. Matrix glasses in basaltic pumice erupted May 28-30 (sample KE62-3293S) contain 10.7-12.6 wt $\% \mathrm{FeO}^{\mathrm{T}}, 5.7-6.5 \mathrm{wt} \% \mathrm{MgO}$, and 0.5-0.6 wt\% $\mathrm{K}_{2} \mathrm{O}(n=45)$. Matrix glasses are progressively depleted in sulfur adjacent to vesicles (100-810 ppm S) but have less variable chlorine (100-170 ppm Cl) (Fig. S13). Interstitial melt and RE contain higher sulfur (590-920 ppm S, $n=21$ ) than matrix glasses, but have the same range of chlorine 


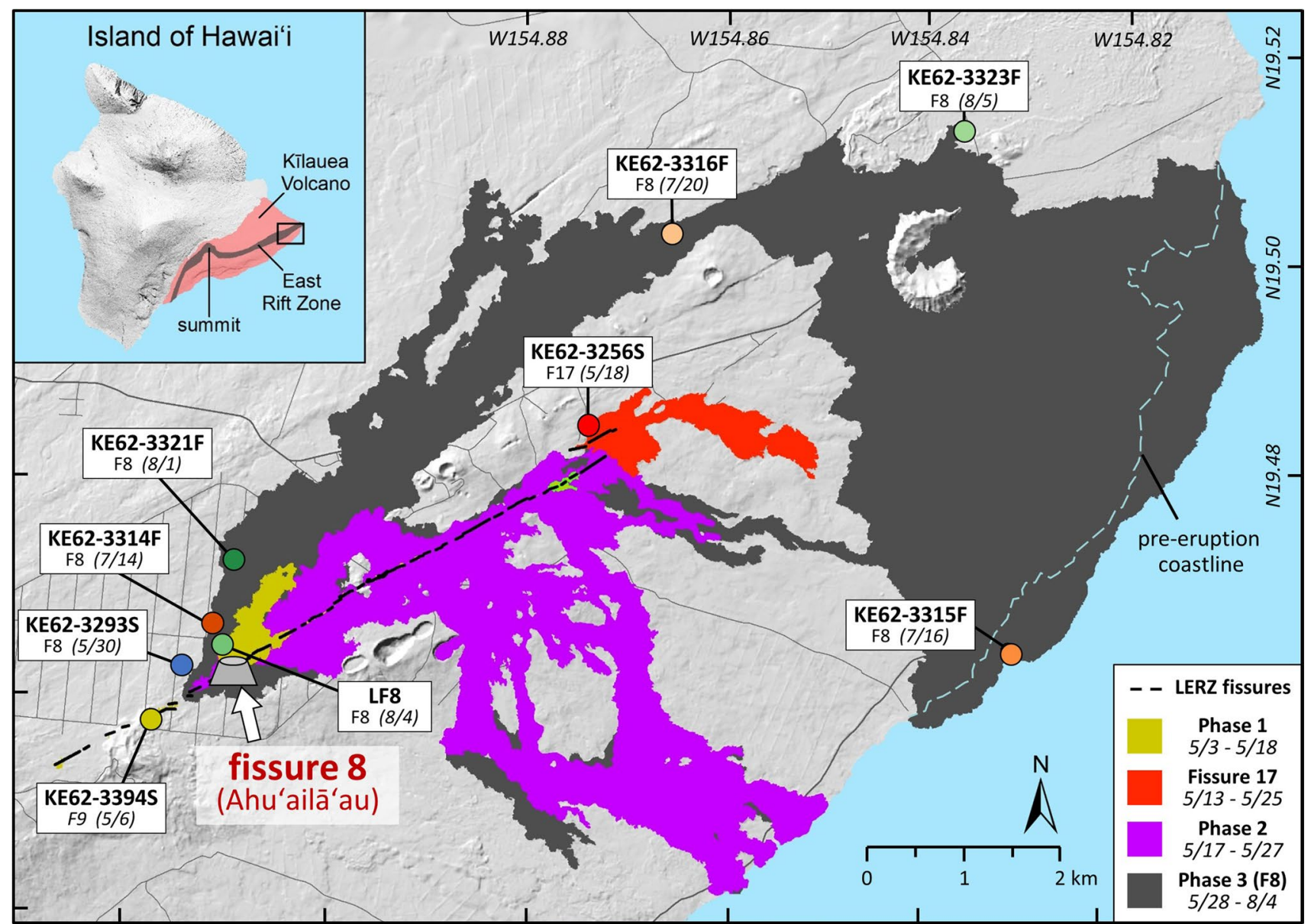

Fig. 1 Lava flow map of the 2018 LERZ eruption of Kîlauea, marked with the locations, fissure sources, and eruption dates of samples presented in this study. Symbol colors are maintained throughout all figures. Subaerial lava flows are colored by eruption phase (Gansecki et al. 2019) but do not include the substantial submarine deposits (Soule et al. 2021). A total of 24 eruptive fissures opened during the eruption, including fissure 9 (F9) and the en-échelon fissure 17 (F17). The main fissure 8 vent (F8) is marked by a schematic cinder cone. (inset) The Island of Hawai' $i$, with the subaerial extent of Kīlauea Volcano highlighted in red. Figure modified from Gansecki et al. (2019) with updated flow extents from Zoeller et al. (2020)

contents in residual glass of the littoral blast sample are 160-230 ppm Cl, and $\mathrm{S} / \mathrm{Cl}$ ratios of the littoral blast matrix glasses range from $<0.1-0.4$, which indicates preferential degassing of sulfur compared to chlorine in the lava channel. We do not observe groundmass sulfides in any F8 phase 3 samples, including the rapidly quenched basaltic pumice.

Analyses of additional samples from earlier stages of the eruption (sample KE62-3394S, an early phase 1 evolved basalt from fissure 9, and sample KE62-3256S, an andesite from fissure 17) are described more extensively in the Supplementary Materials. Interstitial glasses and RE in fissure 9 samples are sulfide-saturated (Fig. S1a-c), and contain 520-1680 ppm S and 250-350 ppm Cl. Fissure 17 matrix glasses are also sulfide-saturated (Fig. 2b) and contain 220-590 ppm S and 900-1000 ppm Cl. No samples from phase 2 of the LERZ eruption were analyzed. 




Fig. 2 Examples of different sulfide occurrences in LERZ samples. (a) $\mathrm{A} \mathrm{Fo}_{86}$ olivine from F8 sample LF8, with a large sulfide and vapor bubble inclusion, along with a small amount of melt. The large proportion of sulfide relative to the melt indicates the sulfide was entrapped as a separate phase in a high temperature sulfide-saturated melt. (b) A phenocryst and groundmass assemblage from fissure 17 (sample KE62-3256S), highlighting the diverse phases present including plagioclase, pyroxenes, apatite, Fe-oxides, and a sulfide.

\section{Melt inclusion textures and compositions}

In F8 samples, we primarily analyzed MI in high-Fo $\left(\mathrm{Fo}_{86-89}\right)$ and lower-Fo olivine $\left(\mathrm{Fo}_{77-85}\right)$, but also analyzed some plagioclase-, clinopyroxene-, and orthopyroxenehosted MI. Vapor bubbles in $\mathrm{Fo}_{88-89}$ olivine-hosted MI constitute $1-8 \%$ of the total MI volume $(n=19)$ compared to $0-4 \%$ of the total MI volume in $\mathrm{Fo}_{80-83}$ olivine. These vapor bubbles likely formed during post-entrapment processes (Riker 2005; Moore et al. 2015; Tuohy et al. 2016; Wieser et al. 2021). The majority of MI in high-Fo olivine contain small spherical sulfide globules $(2-10 \mu \mathrm{m}$ diameter sulfides in 50-150 $\mu \mathrm{m}$ diameter MI) (Fig. 2c, d).

Entrapment temperatures from Mg-thermometry (Helz and Thornber 1987) of PEC-corrected $\mathrm{MI}$ in $\mathrm{Fo}_{86-89}$ olivine are $1220-1310{ }^{\circ} \mathrm{C}$, indicating that $\mathrm{MI}$ in high-Fo olivine experienced $70-170{ }^{\circ} \mathrm{C}$ of pre-eruptive cooling prior to, or during, residence in the $1140-1150{ }^{\circ} \mathrm{C} \mathrm{F} 8$ carrier melts (Figs. S7 and S8). As a result, MI in high-Fo olivine underwent extensive PEC and $\mathrm{Fe}$-loss that depleted $\mathrm{MgO}$ and $\mathrm{FeO}^{\mathrm{T}}$ concentrations after trapping (Figs. S5 and S6). In contrast, $\mathrm{MI}$ in low-Fo olivine, plagioclase, and pyroxene hosts
The sulfide is in contact with the groundmass glass, indicating a low temperature sulfide-saturated melt. (c, d) $\mathrm{Fo}_{88}$ and $\mathrm{Fo}_{89}$ olivine phenocrysts from F8 basaltic pumice (sample KE62-3293S) containing sulfide-bearing MI. The sulfides likely formed during cooling, PEC, and Fe-loss, and can make up substantial fractions of total $\mathrm{S}$ in the MI. (a-c) are backscattered electron images, and (d) is a microphotograph in plane-polarized light

experienced little to no cooling and PEC (Figs. S4-S6). PEC corrections in strongly undercooled MI decrease the analyzed concentrations of olivine-incompatible elements by $30-54 \%$ (Fig. S7). Measured sulfur, chlorine, and $\mathrm{CO}_{2}$ in $\mathrm{MI}$ also decrease during PEC corrections, but measured $\mathrm{H}_{2} \mathrm{O}$ contents were left unchanged because we assume that $\mathrm{H}_{2} \mathrm{O}$ equilibrates in olivine-hosted MI on timescales faster than PEC (see discussion in Supplementary Materials). Unless otherwise stated, all MI compositions discussed hereafter and shown in figures have been corrected for post-entrapment effects.

Melt inclusion compositions $(n=84)$ from LERZ samples fall along the whole-rock and matrix glass liquid line of descent for Killauea, encompassing nearly the full major element variability of measured subaerial and submarine glasses (Fig. 4a). In F8 phase 3 samples, MI in high-Fo olivine $(n=51)$ contain up to $14.5 \mathrm{wt} \% \mathrm{MgO}$ and $0.3-0.4 \mathrm{wt} \% \mathrm{~K}_{2} \mathrm{O}$, whereas $\mathrm{MI}$ in $\mathrm{Fo}_{76-83}$ olivine $(n=22)$, plagioclase $(n=2)$, pyroxene $(n=4)$, and spinel $(n=1)$ contain $5.5-8.5 \mathrm{wt} \% \mathrm{MgO}$ and $0.4-0.6 \mathrm{wt} \% \mathrm{~K}_{2} \mathrm{O}$. Chlorine concentrations in phase $3 \mathrm{MI}$ span a relatively narrow range of 100-250 ppm. Two MI in a rare low-Ca plagioclase phenocryst (anorthite content of $\mathrm{An}_{54}$; where $\mathrm{An}=100 * \mathrm{Ca} /$ 


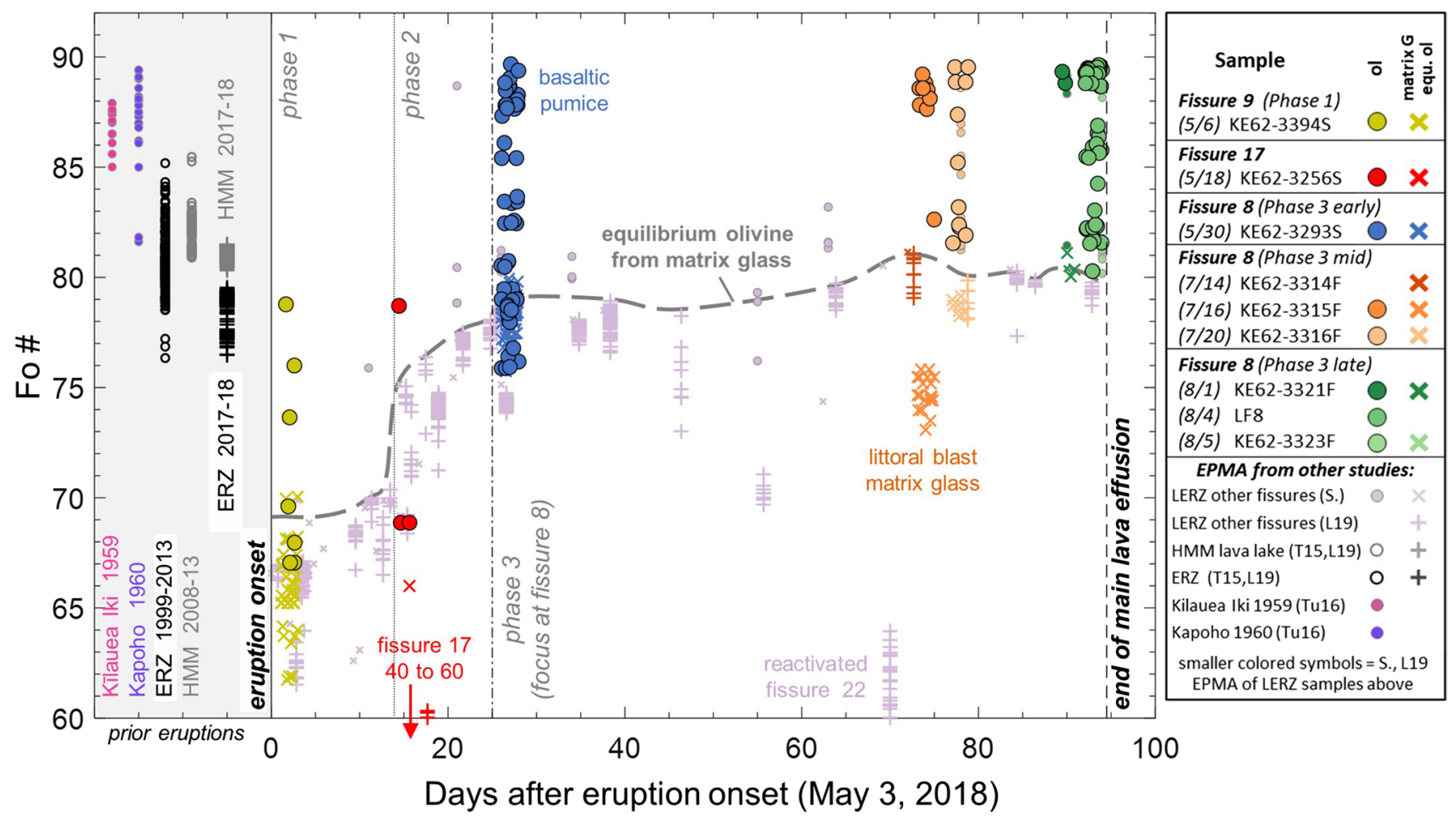

Fig. 3 Time series of measured olivine Fo\# (circles) during the course of the 2018 Kîlauea LERZ eruption. Equilibrium olivine Fo was calculated from matrix glasses (crosses and plus signs) using a melt-olivine $\mathrm{Mg} / \mathrm{Fe}$ exchange coefficient $(\mathrm{Kd})$ of 0.32 for consistency with Petrolog3 PEC calculations after Beattie (1993). The Kd calculations assume $0.18 \mathrm{Fe}^{3+} / \Sigma \mathrm{Fe}$ as representative of pre-eruptive LERZ melt compositions and $0.30 \mathrm{Fe}^{3+} / \Sigma \mathrm{Fe}$ to be appropriate for the oxidized littoral blast sample (Lerner 2020). The eruption dates of samples analyzed in this study have been shifted by \pm 1 day for clarity.

$[\mathrm{Ca}+\mathrm{Na}+\mathrm{K}]$ in molar fractions) from the $\mathrm{F} 8$ basaltic pumice have andesitic compositions that are similar to fissure 17 glasses. These anomalous MI contain low $\mathrm{MgO}(1.1-1.2 \mathrm{wt} \%), \mathrm{FeO}^{\mathrm{T}}$ (6.7-7.1 wt \%), and sulfur (230-350 ppm), and are enriched in chlorine (440-630 ppm).

Sulfur concentrations in LERZ MI are highly variable (350-1390 ppm S), with the highest sulfur in $\mathrm{Fo}_{78-83}$ olivine and $\mathrm{An}_{76}$ plagioclase (1390 and $1320 \mathrm{ppm} \mathrm{S}$, respectively) (Fig. 5). Where present, sulfides account for $11-53 \%$ of the total sulfur in MI (average $29 \% \pm 14 \% ; \pm 1 \sigma$ ), and the average sulfide-restored sulfur content of MI in high-Fo olivine is $680 \pm 240 \mathrm{ppm} \mathrm{S}$ ( \pm 1 s.d., $410-1200$ ppm range, $n=16$ ). Notably, the sulfiderestored sulfur concentrations of many MI in high-Fo olivine are lower than sulfur concentrations of most MI in low-Fo olivine, plagioclase, and pyroxene. A small subset of MI from LF8 were heated to rehomogenize the glass and dissolve sulfides. The sulfur concentrations of reheated $\mathrm{MI}$ in $\mathrm{Fo}_{87-88}$ olivine average $430 \pm 250 \mathrm{ppm} \mathrm{S}$ ( \pm 1 s.d., range $160-630 \mathrm{ppm}, n=3$ ), which is similar to $470 \pm 37 \mathrm{ppm} \mathrm{S}$ ( \pm 1 s.d., range $410-520 \mathrm{ppm}, n=7$ ) in unheated sulfide-restored MI from the same LF8 sample; this similarity suggests that the sulfide mass-balance corrections
The left hand side of diagram shows the ranges of olivine phenocryst compositions and matrix glass equilibrium olivine Fo from past summit and LERZ eruptions of Kîlauea (Thornber et al. 2015 ["T15"]; Tuohy et al. 2016 ["Tu16"]; Lee et al. 2019 [“L19"]). East Rift Zone (ERZ) samples are from $\mathrm{Pu}^{\prime} \mathrm{u}^{\prime} \overline{\mathrm{o}}^{`} \overline{\mathrm{o}}$ and associated fissures. Halema'uma'u (HMM) samples are from the 2008-2018 summit lava lake. Smaller colored symbols are analyses of the same main LERZ samples (e.g., small peach circles for KE62-3316F olivine-hosted MI) measured by Lee et al. (2019) and T. Shea (unpublished data; "S.") accurately account for total sulfur contents in sulfide-bearing MI. Hereafter, we report sulfide-restored sulfur concentrations of MI, unless otherwise indicated. Sulfides were not observed in plagioclase- or pyroxene-hosted MI, consistent with limited PEC-induced sulfide saturation in these phases. Finally, sulfides are not present in MI hosted in $\mathrm{Fo}_{88-89}$ olivine from the littoral blast sample (KE62-3315F) because it became more oxidized during lava transport (Lerner 2020); these sulfide-free MI contain $925 \pm 210$ ppm S ( \pm 1 s.d., $600-1210$ ppm range, $n=8$ ).

\section{$\mathrm{H}_{2} \mathrm{O}$ and $\mathrm{CO}_{2}$ contents of LERZ matrix glasses and melt inclusions}

Melt inclusions in the basaltic pumice were rapidly quenched and therefore are minimally affected by post-eruptive diffusive $\mathrm{H}^{+}$loss. Olivine- and orthopyroxene-hosted MI in the pumice contain $0.20-0.31 \mathrm{wt} \% \mathrm{H}_{2} \mathrm{O}(0.27 \pm 0.03$, avg. \pm 1 s.d., $n=9$ ) and represent the best estimate of preeruptive $\mathrm{H}_{2} \mathrm{O}$ content of $\mathrm{F} 8$ melts, at least during initial phase 3 lava fountaining on May 28-30. $\mathrm{H}_{2} \mathrm{O}$ contents in basaltic pumice matrix glasses range from $0.05-0.33 \mathrm{wt} \%$ 


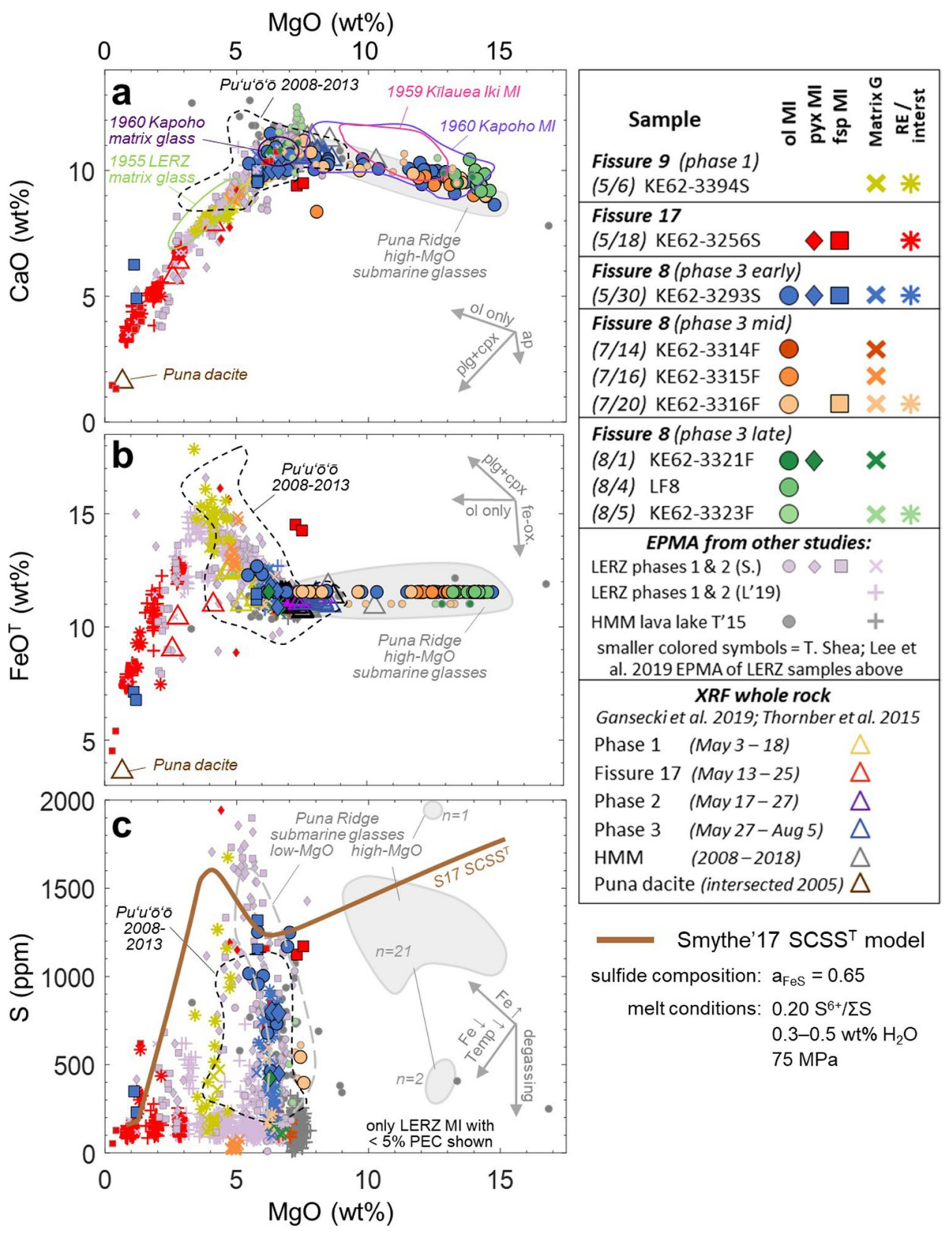

Fig. 4 (a) $\mathrm{CaO}$ vs $\mathrm{MgO}$, (b) $\mathrm{FeO}^{\mathrm{T}}$ vs $\mathrm{MgO}$, and (c) sulfur vs $\mathrm{MgO}$ for MI, matrix glasses, and whole-rocks from the LERZ eruption compared to other Kīlauea samples. All PEC-corrected LERZ MI compositions are shown in (a) and (b), but only MI with $<5 \%$ incompatible element enrichments from PEC and Fe-loss are shown in (c) to avoid complications from post-entrapment sulfide formation. High-Mg LERZ MI have compositions similar to high-Mg submarine glasses from the Puna Ridge (gray shaded ranges; Clague et al. 1995). Crystallization and degassing paths are schematically shown with gray arrows. Analytical uncertainties $( \pm 1 \mathrm{SE})$ for all elements are smaller than symbol sizes. Down-temperature (decreasing $\mathrm{MgO}$ ) sulfur concentration at sulfide saturation $\left(\mathrm{SCSS}^{\mathrm{T}}\right)$ values in $(\mathbf{c})$ are calculated

( $n=12$ ) (Figs. 6a and S15), with $\mathrm{H}_{2} \mathrm{O}$ decreasing closer to vesicles. The littoral blast sample has $0.07-0.11 \mathrm{wt} \% \mathrm{H}_{2} \mathrm{O}$ in matrix glasses $(n=3)$, consistent with the melt having from Smythe et al. (2017) for conditions appropriate for most Kîlauea melt compositions, although SCSS $^{\mathrm{T}}$ will be underestimated for particularly Fe-rich (e.g., phase 1 basalts) and/or $\mathrm{S}^{6+}$-rich melt compositions (see text for details). The $f \mathrm{O}_{2}$ of Kîlauea melts may change due to multiphase fractionation prior to and after the formation of $\mathrm{Fe}$ oxides (Lerner 2020) so that our SCSS ${ }^{\mathrm{T}}$ model conditions may be less appropriate for temperatures $<\sim 1115{ }^{\circ} \mathrm{C}(<\sim 5 \mathrm{wt} \% \mathrm{MgO})$. Smaller colored symbols are analyses of the same main LERZ samples (e.g., small red diamonds are for fissure 17 pyx-hosted $\mathrm{MI}$ ) measured by Lee et al. (2019) and T. Shea (unpublished data; "S."). Other data sources are Thornber et al. (2015), Gansecki et al. (2019), and Tuohy et al. (2016)

equilibrated to 1-atm conditions (Dixon et al. 1995) during subaerial transport to the coast. Olivine-hosted MI in the littoral blast and LF8 lava flow samples contain 0.08-0.17 wt\% 


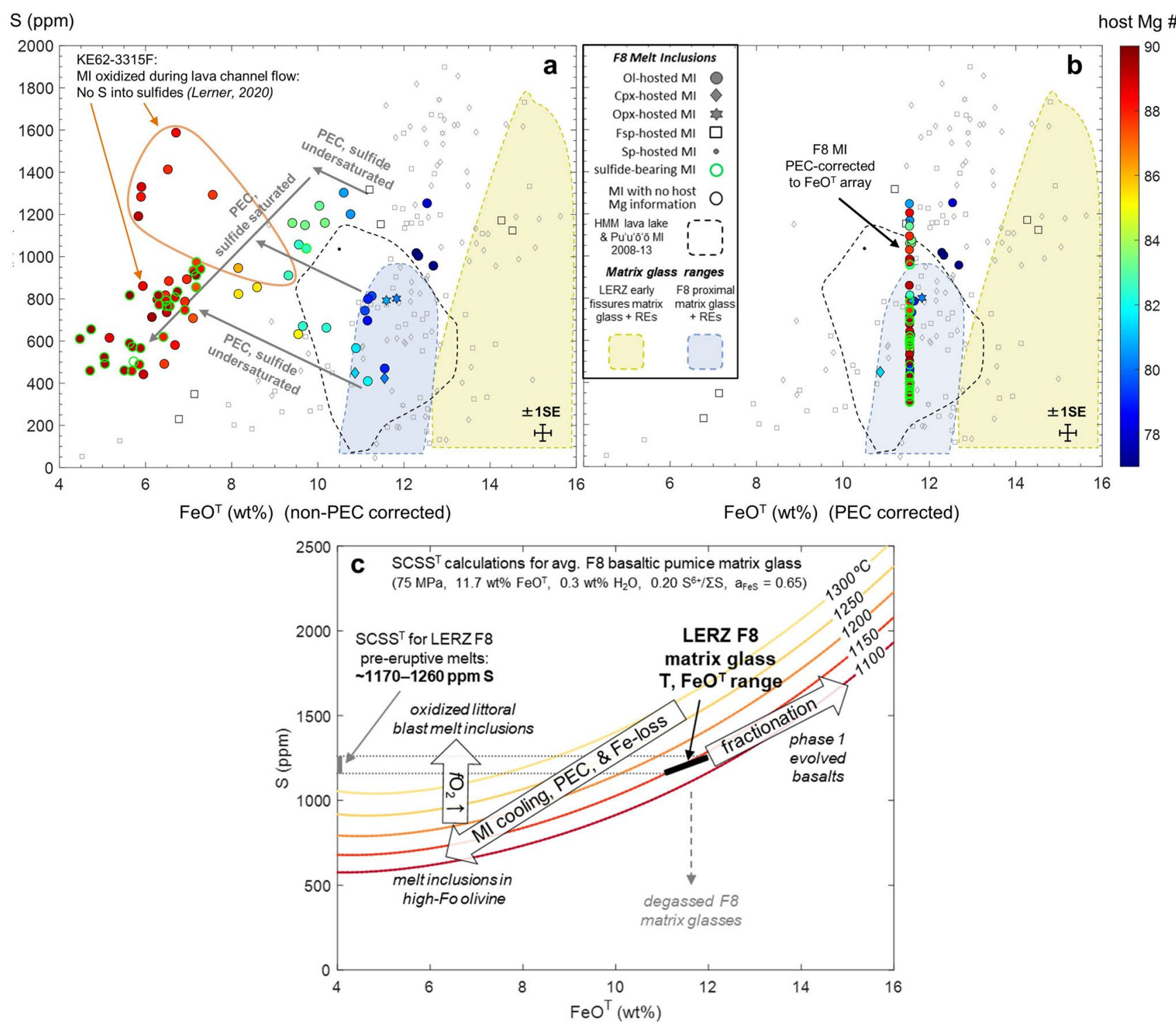

Fig. 5 (a) Non-PEC corrected and (b) PEC-corrected $\mathrm{FeO}^{\mathrm{T}}$ and sulfur concentrations of olivine-hosted MI from LERZ phase 3 magmas erupted from F8. Symbols are colored by host Mg\# (for olivine and pyroxenes). Symbols with green outlines are MI that contain sulfides; sulfide masses have not been added to MI sulfur concentrations shown here. Compositional ranges of olivine-hosted MI and matrix glasses from Halema'uma'u (HMM) and $\mathrm{Pu}^{`} \mathrm{u}^{`} \mathrm{o}^{`}{ }^{`} \mathrm{o}$ (20082013, Thornber et al. 2015) are shown as a gray colored field. Matrix glasses from F8 and from phase 1 and 2 LERZ fissures are shown as blue and yellow colored fields, respectively. Plagioclase- and pyrox-

$\mathrm{H}_{2} \mathrm{O}(n=7)$ and $0.10-0.27 \mathrm{wt} \% \mathrm{H}_{2} \mathrm{O}(n=4)$ respectively, indicating varying extents of diffusive $\mathrm{H}^{+}$equilibration with the degassed external melt. Similar ranges of $0.2-0.3 \mathrm{wt} \%$ $\mathrm{H}_{2} \mathrm{O}$ have been measured in olivine-hosted MI from F8 by Wieser et al. (2021).

$\mathrm{H}_{2} \mathrm{O}$ was not measured in fissure 9 or fissure 17 matrix glasses or MI. However, two andesitic $\mathrm{MI}$ in an $\mathrm{An}_{54}$ plagioclase from the F8 basaltic pumice have major element ene-hosted MI from LERZ phase 1 and 2 magmas (T. Shea, unpublished data) are respectively shown as small unfilled rectangles and diamonds. (c) $\mathrm{SCSS}^{\mathrm{T}}$ variations with melt $\mathrm{FeO}^{\mathrm{T}}$ and temperature, calculated using the model of Smythe et al. (2017) for Kilauea LERZ F8 basaltic pumice (sample KE62-3293S) pre-eruptive melt conditions ( $75 \mathrm{MPa}, 0.20 \mathrm{~S}^{6+} / \Sigma \mathrm{S}$, sulfide $\mathrm{a}_{\mathrm{FeS}}$ of 0.65 ; see text). The range of measured F8 matrix glass temperatures and $\mathrm{FeO}^{\mathrm{T}}$ is shown in black. Processes that affected sulfide saturation in particular types of LERZ melts and MI are schematically illustrated

compositions similar to fissure 17 glasses and thus represent entrained crystals from evolved fissure 17-like magmas. Compared to basaltic MI, these evolved $\mathrm{MI}$ have elevated $\mathrm{H}_{2} \mathrm{O}$ and chlorine contents $\left(0.31\right.$ and $0.55 \mathrm{wt} \% \mathrm{H}_{2} \mathrm{O}, 440$ and $630 \mathrm{ppm}$ $\mathrm{Cl}$ ), but low sulfur (230-350 ppm S; Figs. S15 and S16).

$\mathrm{CO}_{2}$ concentrations in MI glasses were below detection limits $(\sim 50 \mathrm{ppm})$ in all $\mathrm{F} 8$ phase 3 samples except for two bubble-free MI in the basaltic pumice. These bubble-free 


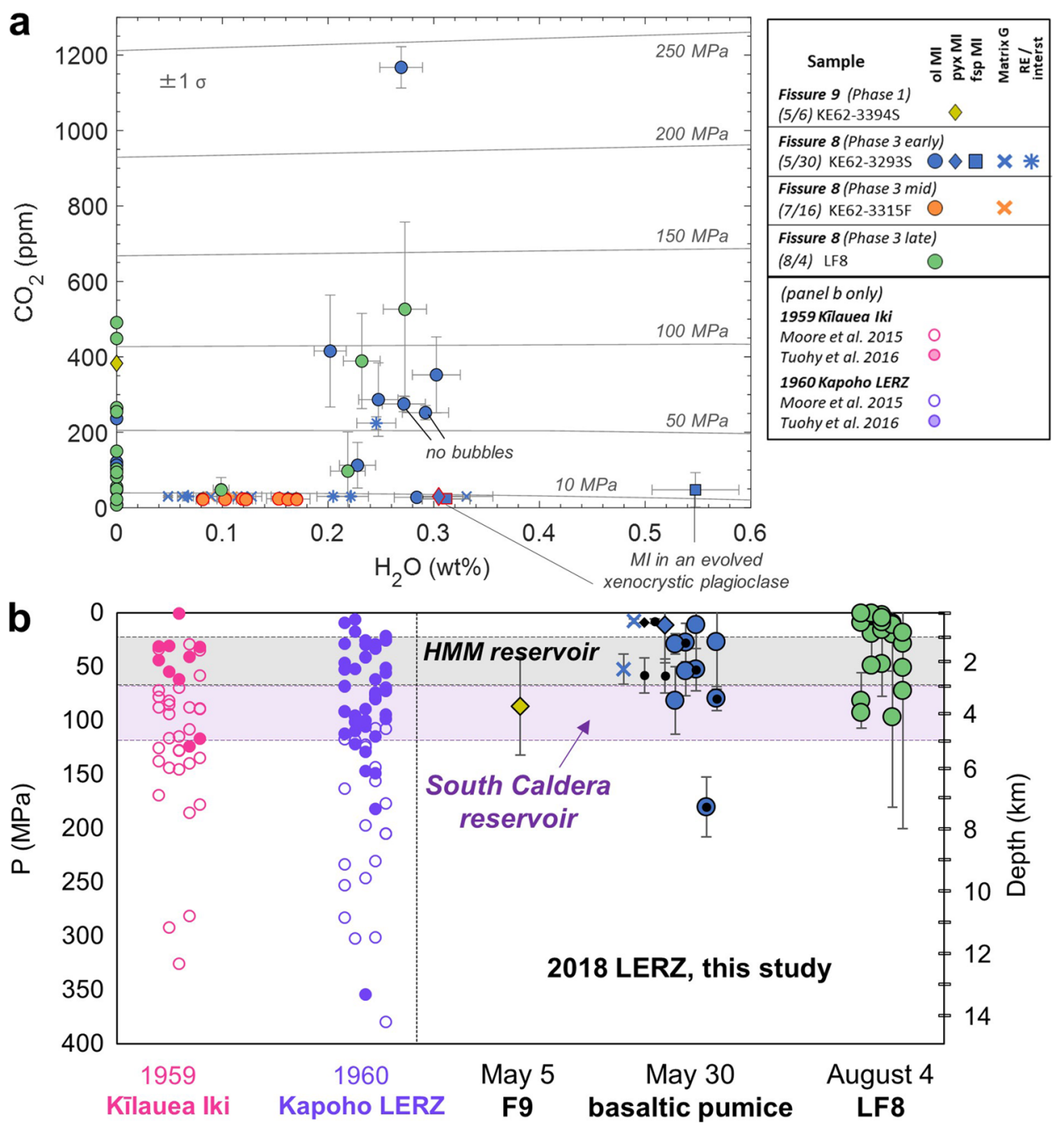

Fig. 6 (a) $\mathrm{H}_{2} \mathrm{O}-\mathrm{CO}_{2}$ measurements of $\mathrm{MI}$ and matrix glasses from LERZ samples. Symbols with black borders and measured $\mathrm{H}_{2} \mathrm{O}$ indicate $\mathrm{H}_{2} \mathrm{O}$ and $\mathrm{CO}_{2}$ from FTIR and Raman; symbols at 0 wt\% $\mathrm{H}_{2} \mathrm{O}$ are Raman $\mathrm{CO}_{2}$-only measurements; symbols with red borders indicate $\mathrm{CO}_{2}$ and $\mathrm{H}_{2} \mathrm{O}$ from FTIR-only in bubble-bearing MI. The two bubble-free MI with FTIR-resolvable $\mathrm{CO}_{2}$ are indicated. Variably degassed matrix glasses analyzed by FTIR are shown as crosses and RE and interstitial melts are shown as asterisks. Where $\mathrm{CO}_{2}$ in MI glass was below FTIR detection limits, glass concentrations of $30 \mathrm{ppm} \mathrm{CO}_{2}$ are assumed. Saturation pressure isobars are calculated for the average basaltic pumice matrix glass composition at $1140{ }^{\circ} \mathrm{C}$ (Iacono-Marziano et al. 2012). (b) Melt inclusion $\mathrm{H}_{2} \mathrm{O}-\mathrm{CO}_{2}$ saturation pressures and corresponding entrapment depths below the surface for LERZ samples (horizontally shifted to reduce overlap; $\pm 1 \sigma$ propagated uncertainty on $\mathrm{CO}_{2}$ concentrations). Saturation pressures are temperature and composition specific (Iacono-Marziano et al. 2012), resulting in some differences compared to the isobars in (a). Only matrix glasses with resolvable $\mathrm{CO}_{2}$, MI with Ramanmeasured vapor bubbles, and bubble-free MI measured by FTIR are

MI are hosted in $\mathrm{Fo}_{81}$ and $\mathrm{Fo}_{83}$ olivine and respectively contain $0.29 \mathrm{wt} \% \mathrm{H}_{2} \mathrm{O}$ and $250 \mathrm{ppm} \mathrm{CO}$, and $0.27 \mathrm{wt} \%$ $\mathrm{H}_{2} \mathrm{O}$ and $280 \mathrm{ppm} \mathrm{CO}_{2}$. Vapor bubbles have been shown to contain $55-90 \%$ of total $\mathrm{CO}_{2}$ in Kîlauea MI (Moore shown. No littoral blast (KE62-3315F) samples appear in (b) because MI were not analyzed by Raman. Symbology for LERZ samples is the same as in (a) except that solitary dots indicate FTIR measurements in bubble-free MI and circles with dots indicate combined Raman and FTIR measurements. (b, left side) Melt inclusion entrapment depths from 1959 Kīlauea Iki and 1960 Kapoho samples from Moore et al. (2015) and Tuohy et al. (2016), where $\mathrm{CO}_{2}$ in bubbles was, respectively, determined by Raman spectroscopy or calculated with a PEC and bubble formation model and experimental homogenization. Saturation pressures from Moore et al. (2015) and Tuohy et al. (2016) MI were calculated from Iacono-Marziano et al. (2012) at $1250{ }^{\circ} \mathrm{C}$ assuming the average MI composition from Tuohy et al. (2016), including $170 \mathrm{ppm} \mathrm{CO}_{2}$ in the MI glass and a PEC correction factor of 0.87 if not directly measured. Pressure to depth calculations follow the parameterization of Ryan (1987) (see Supplementary Materials). Estimated depths of the Halema'uma'u (HMM) and South Caldera summit magma reservoirs are from Poland et al. (2014) and Anderson et al. (2019)

et al. 2015; Tuohy et al. 2016), and the extensive PEC in many F8 MI formed large vapor bubbles (Fig. S17) that sequestered the majority of $\mathrm{CO}_{2}$ (Wieser et al. 2021). Consequently, even for LERZ MI that lack FTIR glass 
measurements, the bubble-only $\mathrm{CO}_{2}$ determinations are largely representative of the total $\mathrm{CO}_{2}$ in the $\mathrm{MI}$. $\mathrm{CO}_{2}$ densities in vapor bubbles within olivine-hosted MI from F8 samples are generally low $\left(\sim 0.02-0.03 \mathrm{~g} / \mathrm{cm}^{3}\right)$. PEC-corrected mass balance results in total calculated $\mathrm{CO}_{2}$ concentrations in MI (bubble + melt) of $<50-530 \mathrm{ppm}(n=30)$ (Fig. 6a). One outlier MI in a basaltic pumice high-Fo olivine has a vapor bubble $\mathrm{CO}_{2}$ density of $0.07 \mathrm{~g} / \mathrm{cm}^{3}$ and a total $\mathrm{MI} \mathrm{CO}_{2}$ concentration of $1170 \mathrm{ppm}$. Propagated relative uncertainties in $\mathrm{MI} \mathrm{CO}_{2}$ concentrations range from $\pm 4-140 \%$ depending on bubble $\mathrm{CO}_{2}$ density and bubble and MI size, with a median of $\pm 32 \%(1 \sigma, n=21)$. Small particles are present on the walls of some MI vapor bubbles, but Raman analyses of these presumed condensates did not show evidence of these being either carbonate or sulfur-bearing phases (see also Wieser et al. 2021).

$\mathrm{CO}_{2}$ concentrations were below detection limits in all matrix glasses $(n=13)$ except for one analysis of interstitial melt in a basaltic pumice sample. In this particular interstitial melt region, volatile loss was presumably reduced due to diffusion pathways being limited by tightly bounding crystals. This interstitial melt glass contained $0.25 \mathrm{wt} \% \mathrm{H}_{2} \mathrm{O}$ and $224 \mathrm{ppm} \mathrm{CO}$, providing a minimum estimate for pre-eruptive $\mathrm{CO}_{2}$ concentrations in F8 melts erupting in late May.

\section{Sulfur isotopes}

Basaltic pumice matrix glasses have $\delta^{34} \mathrm{~S}$ values ranging from -2.8 to $+0.3 \%$ o $(n=10)$ over a range of $100-800 \mathrm{ppm} \mathrm{S}$ concentrations. $\delta^{34} \mathrm{~S}$ in basaltic pumice MI ranges from -1.2 to $+0.5 \%$ in sulfur-poor inclusions $(330-790 \mathrm{ppm} \mathrm{S,} n=4)$, but reaches values of +1.0 to $+1.5 \%$ in more sulfur-rich inclusions (1170-1390 ppm S, $n=2)$. Melt inclusions in the littoral blast and LF8 samples have respective $\delta^{34} \mathrm{~S}$ ranges of -0.7 to $+0.9 \%$ o $(n=5)$ and -1.6 to $-0.7 \%$ o $(n=4)$, across respective sulfur concentration ranges of 600-1100 and $390-640$ ppm S. The collective suite of F8 glasses exhibits a clear relation between $\delta^{34} \mathrm{~S}$ values and sulfur concentrations, with both matrix glasses and MI becoming isotopically lighter with decreasing sulfur concentration (Fig. 9). Although a number of analyzed F8 MI contain sulfides, the total isotopic fractionation between the relatively reduced MI and precipitated sulfides is close to $0 \%$ at Kîlauea temperatures and $f \mathrm{O}_{2}$ conditions (Marini et al. 2011; Labidi and Cartigny 2016), so that glass measurements are representative of the total MI $\delta^{34} \mathrm{~S}$ value (Beaudry et al. 2018). Any effect of sulfide precipitation is predicted to be less than our analytical uncertainties, so we do not apply isotopic corrections to sulfide-bearing MI. Indeed, measured $\delta^{34} \mathrm{~S}$ values and sulfide-restored total sulfur concentrations of the sulfide-bearing MI have the same correlation as observed in non-sulfide bearing MI and matrix glasses.

\section{Down-temperature SCSS modeling of Kïlauea melts}

Sulfur content at sulfide saturation (SCSS) is the amount of sulfur that can be dissolved in a melt before an immiscible sulfide phase is exsolved. SCSS is dependent on melt temperature, pressure, composition (principally $\mathrm{FeO}^{\mathrm{T}}$ ), and sulfide composition (Wallace and Carmichael 1992; Jugo et al. 2010; Fortin et al. 2015; Smythe et al. 2017). We calculate the expected down-temperature variation of SCSS for Kīlauea primary melts based on matrix and submarine glass compositions and temperatures across the full range of published Kîlauea compositions (0.8-15 wt\% $\mathrm{MgO} ; 1030-1320^{\circ} \mathrm{C}$ ), from andesitic and dacitic glasses of fissure 17 to high-Mg submarine glasses of the Puna Ridge (Clague et al. 1995; Lee et al. 2019; this study) (Figs. 4, S3, and S16). Glass compositions that align with the overall Kìlauea glass and whole-rock $\mathrm{MgO}$ and $\mathrm{FeO}^{\mathrm{T}}$ arrays (Fig. 4b) were chosen for representative downtemperature SCSS calculations. Pressure is assumed to be $75 \mathrm{MPa}(\sim 3.3 \mathrm{~km}$ depth$)$, and $\mathrm{H}_{2} \mathrm{O}$ contents are assumed to be $0.5 \mathrm{wt} \% \mathrm{H}_{2} \mathrm{O}$ for temperatures $>1140{ }^{\circ} \mathrm{C}$ and 0.3 wt $\% \mathrm{H}_{2} \mathrm{O}$ for temperatures $\leq 1140{ }^{\circ} \mathrm{C}$ (Clague et al. 1995; Wallace and Anderson 1998; Edmonds et al. 2013; Sides et al. 2014b). We use the SCSS formulation of Smythe et al. (2017) and assume a sulfide composition with molar $\mathrm{Fe} /(\mathrm{Fe}+\mathrm{Cu}+\mathrm{Ni}) \approx 0.65\left(\mathrm{a}_{\mathrm{FeS}}=0.65\right)$, which is appropriate for sulfides in high temperature Kîlauea magmas (Wieser et al. 2020). For simplicity we maintain this sulfide composition for all temperatures, although sulfide composition may change significantly in low temperature Kîlauea melts (Stone and Fleet 1991; Greaney et al. 2017). The SCSS model of Smythe et al. (2017) assumes only $\mathrm{S}^{2-}$ in the melt, but Jugo et al. (2010) show that the SCSS is exponentially dependent on the $S^{6+} / \Sigma S$ proportion in the melt. We account for this sulfur speciation dependence by scaling the Smythe et al. (2017) model calculations by the Jugo et al. (2010) exponential $S^{6+} / \Sigma S$ relation (Longpré et al. 2017; Wieser et al. 2020). This mixed $S^{2-}$ and $\mathrm{S}^{6+}$ solubility provides a "total SCSS" $\left(\mathrm{SCSS}^{\mathrm{T}}\right)$ estimate. Lerner (2020) measured $0.1-0.3 \mathrm{~S}^{6+} / \Sigma S$ in proximally quenched F8 MI, and we use a constant median estimate of $0.2 \mathrm{~S}^{6+} / \Sigma \mathrm{S}$ for $\mathrm{SCSS}^{\mathrm{T}}$ calculations here. Modeling $\mathrm{SCSS}^{\mathrm{T}}$ with a sulfide composition of $\mathrm{a}_{\mathrm{FeS}}=0.65$ decreases the $\operatorname{SCSS}^{\mathrm{T}}$ by $35 \%$ compared to $\mathrm{a}_{\mathrm{FeS}}=1$, and the inclusion of $0.2 \mathrm{~S}^{6+} / \Sigma \mathrm{S}$ increases the $\operatorname{SCSS}^{\mathrm{T}}$ by $25 \%$ compared to sulfate-free $\mathrm{SCSS}^{2-}$ calculations.

The resulting down-temperature (decreasing $\mathrm{MgO}$ ) $\mathrm{SCSS}^{\mathrm{T}}$ model reproduces the upper ranges of observed sulfur concentrations in Kīlauea melts fairly well (Figs. $4 \mathrm{c}$ and S16c). In high-MgO melts, $\mathrm{SCSS}^{\mathrm{T}}$ gradually decreases with decreasing temperature. Kìlauea melt fractionation is dominated by olivine crystallization until 7-8 wt \% $\mathrm{MgO}\left(1150-1175^{\circ} \mathrm{C}\right)$ (Thornber et al. 2015), but at lower temperatures clinopyroxene and plagioclase join the 
crystallizing assemblage and the $\mathrm{FeO}^{\mathrm{T}}$ content of the melt increases from $11.5 \mathrm{wt} \%$ to $15 \mathrm{wt} \%$ over a relatively narrow change of temperature. The strong dependence of sulfur solubility on $\mathrm{FeO}^{\mathrm{T}}$ concentration leads to a maximum $\operatorname{SCSS}^{\mathrm{T}}$ in melt compositions with 3.5-5.5 wt $\% \mathrm{MgO}\left(1080-1125^{\circ} \mathrm{C}\right)$ where $\mathrm{FeO}^{\mathrm{T}}$ concentrations approach $15 \mathrm{wt} \%$. Many phase 1 evolved basalts have these high- $\mathrm{FeO}^{\mathrm{T}}$ compositions (Gansecki et al. 2019), which is consistent with the elevated sulfur concentrations (up to $2000 \mathrm{ppm}$ ) measured in phase $1 \mathrm{MI}$ and interstitial melts (Figs. 4 and 5). With further decreasing melt temperatures, Fe-oxides begin crystallizing and strongly deplete $\mathrm{FeO}^{\mathrm{T}}$ in the melt. The combination of decreasing melt temperature and $\mathrm{FeO}^{\mathrm{T}}$ concentrations results in the steep decrease in $\mathrm{SCSS}^{\mathrm{T}}$ in Kỉlauea melts with $<3 \mathrm{wt} \% \mathrm{MgO}$.

\section{Discussion}

\section{Compositional diversity of LERZ melts}

Combining our MI and mineral datasets with other published LERZ whole-rock and glass compositions (Gansecki et al. 2019; Lee et al. 2019), we find that the diversity of mineral and glass compositions erupted from the 2018 LERZ fissures span nearly the entire known range of Kîlauea volcanic products (Figs. 3, 4, and S3). Early erupted basalts from phases 1 and 2 involve long-stored magmas that had undergone substantial fractionation within the LERZ (Gansecki et al. 2019; Lee et al. 2019) and partially mixed with the more mafic magmas that erupted in phase 3 (Gansecki et al. 2019). The fissure 17 andesite is a result of particularly high degrees of fractionation during prolonged LERZ storage and cooling (Gansecki et al. 2019). Two evolved MI with andesitic, fissure 17-like compositions have elevated $\mathrm{K}_{2} \mathrm{O}, \mathrm{H}_{2} \mathrm{O}$, and chlorine compared to basaltic MI (Figs. 6a and $\mathrm{S} 15$ ), and fissure 17 matrix glasses contain very high $\mathrm{K}_{2} \mathrm{O}$ and chlorine (up to $2.5 \mathrm{wt} \% \mathrm{~K}_{2} \mathrm{O}$ and $1000 \mathrm{ppm} \mathrm{Cl}$ ), consistent with expected incompatible behavior of $\mathrm{K}_{2} \mathrm{O}$ and chlorine during fractionation (Anderson 1974) (Fig. S16).

Melt inclusions in phase 3 lavas from F8 are hosted in olivine with core compositions of $\mathrm{Fo}_{76-89}$ (Fig. 3). Melt inclusions in $\mathrm{Fo}_{76-80}$ olivine that were in equilibrium with the $\mathrm{F} 8$ carrier melt $\left(1140-1150{ }^{\circ} \mathrm{C}\right)$ experienced little to no PEC (Fig. S7) and have compositions similar to plagioclase- and pyroxene-hosted MI. These MI in low-Fo olivine, plagioclase, and pyroxene (hereafter "melt-cognate" MI) have compositions consistent with matrix glasses and equilibrium melt temperatures $\left(1135-1145{ }^{\circ} \mathrm{C}\right)$ of $\mathrm{Pu}^{\prime} u^{\top} \bar{o}^{`}{ }^{`}$ magmas erupted between 2012 and 2018 (Thornber et al. 2015; Gansecki et al. 2019; Lee et al. 2019). Melt inclusions in $\mathrm{Fo}_{80-82}$ olivine have compositions and equilibrium temperatures $\left(1150-1160{ }^{\circ} \mathrm{C}\right)$ similar to tephra from the Halema'uma'u summit lava lake (Rowe et al. 2015; Thornber et al. 2015; Gansecki et al. 2019; Lee et al. 2019).
High-Mg olivine $\left(\mathrm{Fo}_{86-89}\right)$ first appeared in phase 2 lavas on May 20, and became a significant proportion of the phenocryst cargo in phase 3 magmas (Gansecki et al. 2019; Wieser et al. 2021; Mourey et al. 2019) (Fig. 3). Melt inclusions in high-Fo olivine preserve compositions of primitive Kīlauea magmas and yield calculated entrapment temperatures of $1250-1310^{\circ} \mathrm{C}$. High-Fo olivine grains are in clear disequilibrium with the lower temperature F8 carrier melt. Melt inclusions within high-Fo olivine experienced $70-170{ }^{\circ} \mathrm{C}$ of cooling either before or during residence in the LERZ melt, causing extensive PEC (Fig. S7). In the more slowly cooled lava flow sample LF8, Mg-thermometry of MI within high-Fo olivine indicate that these inclusions experienced up to $240{ }^{\circ} \mathrm{C}$ cooling prior to quenching. Melt inclusions in high-Fo olivine have PEC-restored $\mathrm{MgO}$ contents of 10-14.5 wt \%. Similar highly primitive PEC-restored compositions have been reported for other $\mathrm{MI}$ in high-Fo olivine from F8 (Wieser et al. 2021).

The high-Fo olivine in F8 magmas could not have formed in the lower temperature F8 carrier melt and are not necessarily cogenetic with recently erupted magma at Kîlauea. Garcia et al. (2003) and Pietruszka et al. $(2015,2018)$ demonstrated that Kîlauea magmas are generated from melting of a heterogeneous mantle source that imparts distinct isotopic and trace-element signatures that vary through time. Using $\mathrm{K}_{2} \mathrm{O} / \mathrm{TiO}_{2}$ ratios in $\mathrm{MI}$ and matrix glasses to assess potential petrogenic relations, we find that $70 \%$ of $\mathrm{MI}$ in high-Fo olivine overlap the range of $\mathrm{K}_{2} \mathrm{O} / \mathrm{TiO}_{2}$ in $\mathrm{F} 8$ matrix glasses $(0.17-0.22)$, suggesting that these primitive grains are likely related to recent magmatism at Kîlauea (Fig. S10). The $~ 30 \%$ of $\mathrm{MI}$ in high-Fo with anomalous $\mathrm{K}_{2} \mathrm{O} / \mathrm{TiO}_{2}$ ratios may be antecrysts related to prior periods of magmatism. However, these potential antecrystic MI have ranges of volatile concentrations, entrapment depths, $\delta^{34} \mathrm{~S}$, and most major elements that mirror those of MI from our full LERZ 2018 dataset, and thus do not strongly skew any of our datasets (see Supplementary Materials for further details).

The primitive glass compositions of PEC-corrected MI in high-Fo olivine are compositions rarely observed in subaerial Kîlauea eruptions (Helz et al. 2015; Thornber et al. 2015) but have been documented in submarine "turbidite sand" glass grains from the Puna Ridge (the offshore extension of the ERZ) (Clague et al. 1995) (Figs. 4 and S5). Previous LERZ eruptions also contained abundant high-Fo olivine grains with primitive MI, such as the 1960 Kapoho eruption (Tuohy et al. 2016). High-Fo olivine from higher-temperature summit reservoirs seems to be preferentially entrained and erupted during LERZ and offshore Puna Ridge eruptions (Clague et al. 1995; Tuohy et al. 2016), although eruptions at the summit and middle ERZ do occasionally contain abundant high-Fo olivine (e.g., 1959 Kīlauea Iki, 1969-1974 Mauna Ulu [Anderson and Brown 1993; Vinet and Higgins 2011; Sides et al. 2014b; Helz et al. 2015, 2017; Tuohy et al. 2016]). 


\section{Vapor saturation pressures and melt inclusion entrapment depths}

$\mathrm{H}_{2} \mathrm{O}$ and total $\mathrm{CO}_{2}$ measurements in $\mathrm{MI}$ allow estimations of entrapment depths, which provide information on the storage depths of magmas that were tapped during LERZ eruptions. $\mathrm{H}_{2} \mathrm{O}-\mathrm{CO}_{2}$ vapor saturation pressures were calculated using the composition-dependent solubility model from Iacono-Marziano et al. (2012), which is well calibrated for tholeiitic basalts. Kīlauea magmas are likely saturated with a $\mathrm{CO}_{2}$-rich vapor phase throughout the crust (Gerlach and Graeber 1985; Gerlach 1986; Gerlach et al. 2002; Anderson and Poland 2017), and vapor saturation pressures can therefore be used to calculate MI entrapment depths (Anderson and Brown 1993). The rapid rate of $\mathrm{H}^{+}$diffusion through olivine (Hauri 2002; Portnyagin et al. 2008; Bucholz et al. 2013; Barth et al. 2019) likely caused olivine-hosted MI to equilibrate with the $\mathrm{H}_{2} \mathrm{O}$ content of the bulk LERZ carrier melt during the $\sim 40 \mathrm{~km}$ dike transport from summit reservoirs to the LERZ, and thus olivine-hosted MI may not preserve initial $\mathrm{H}_{2} \mathrm{O}$ concentrations. However, for low- $\mathrm{H}_{2} \mathrm{O}$ basalts, such as at Kīlauea, vapor saturation pressures are dominantly controlled by $\mathrm{CO}_{2}$ contents (Fig. 6a). Consequently, any diffusive $\mathrm{H}^{+}$-loss from LERZ MI has little effect on calculated entrapment pressures.

The majority of MI in F8 samples from late May (basaltic pumice KE62-3293S) and early August (lava overflow LF8) that contain vapor bubbles have $\mathrm{H}_{2} \mathrm{O}-\mathrm{CO}_{2}$ saturation pressures of 2-100 MPa, which correspond to entrapment depths of $<0.1-4.0 \mathrm{~km}$ beneath the surface (Fig. 6b). These bubble-bearing MI are mostly hosted in high-Fo olivine and both samples have comparable depth distributions. Wieser et al. (2021) similarly find MI entrapment depths of 2-5 km in bubble-bearing MI from F8 samples (Fig. S18). These relatively shallow entrapment depths of F8 MI are similar to the $\sim 1-5 \mathrm{~km}$ entrapment depths determined by Tuohy et al. (2016) for many $\mathrm{MI}$ in $\mathrm{Fo}_{86-89}$ olivine from the 1959 Kīlauea Iki and 1960 Kapoho eruptions, which were calculated with bubble-restored $\mathrm{CO}_{2}$.

Two MI in lower-Fo olivine $\left(\mathrm{Fo}_{81,83}\right)$ that did not contain vapor bubbles both have $\mathrm{H}_{2} \mathrm{O}$ and $\mathrm{CO}_{2}$ concentrations in glass that yield vapor saturation pressures of $\sim 58 \mathrm{MPa}$, corresponding to entrapment pressures of $\sim 2.5 \mathrm{~km}$. These depths are similar to entrapment depths of 1-3 km determined for bubble-free MI in other F8 samples measured by Wieser et al. (2021) (Fig. S18) and for bubble-free MI from 1959 Kīlauea Iki measured by Anderson and Brown (1993).

One outlier MI from a basaltic pumice high-Fo olivine contains an anomalously $\mathrm{CO}_{2}$-rich vapor bubble and has a calculated entrapment depth of $\sim 7.3 \mathrm{~km}$ (180 MPa). Tuohy et al. (2016) and Wieser et al. (2021) also observe some MI with entrapment depths $>5$ km from the 1959 Kīlauea Iki, 1960 Kapoho, and
2018 LERZ eruptions, but such MI are less common (Fig. 6b). Moore et al. (2015) find mostly similar entrapment depths of $<7 \mathrm{~km}$ for Kīlauea Iki MI, but greater entrapment depths for some Kapoho MI. Several other studies (Edmonds et al. 2013; Sides et al. 2014a, b; Moussallam et al. 2016) report MI entrapment depths of mostly $\geq 1-3 \mathrm{~km}$, and rarely $\geq 4-6 \mathrm{~km}$ for a number of Kīlauea summit eruptions including 1885, Kîlauea Iki 1959, and Halema' uma'u lava lake 2008-2010. However, these are minimum entrapment depths because $\mathrm{CO}_{2}$ sequestration into MI vapor bubbles was not accounted for.

In summary, MI in magmas feeding the 2018 LERZ eruption were dominantly trapped at shallow depths of $1-5 \mathrm{~km}$ (Wieser et al. 2021; this study), which is in notable contrast to the 1959 Kîlauea Iki and 1960 Kapoho eruptions that contained greater proportions of more deeply entrapped MI (Anderson and Brown 1993; Moore et al. 2015; Tuohy et al. 2016). The shallow entrapment depths of MI in 2018 LERZ magmas are consistent with the geophysically determined extents of the Halema'uma'u (1-3 km depths) and South Caldera reservoirs (3-5 km depths) (Poland et al. 2014; Anderson et al. 2019) (Figs. 6b and S18).

\section{Sulfur variability and sulfide saturation in LERZ magmas}

\section{Pre-eruptive sulfur concentrations of phase 3 melts}

Constraints on pre-eruptive sulfur concentrations in F8 phase 3 melts come from matrix glass regions that were partially isolated from degassing (interstitial melts and RE) and from MI in minerals that likely formed within the LERZ carrier melt. Re-entrant melt channels in rapidly quenched $\mathrm{F} 8$ basaltic pumice have lower sulfur concentrations (370-420 ppm S) at their mouths compared to RE interiors (760-920 ppm S). Interstitial melts in the basaltic pumice are partially shielded from diffusive volatile loss by surrounding crystals and contain $600-810 \mathrm{ppm}$ $\mathrm{S}$, whereas degassed matrix glass near vesicles contain as little as $100-200 \mathrm{ppm} \mathrm{S}$. However, it is probable that interstitial melts and even RE interiors had partially degassed during ascent, and therefore provide minimum estimates of pre-eruptive sulfur concentrations.

Melt inclusions are closed systems with respect to sulfur, and $\mathrm{MI}$ in minerals cognate to $\mathrm{F} 8$ carrier melts $\left(\mathrm{Fo}_{76-83}\right.$ olivine, plagioclase, clinopyroxene, orthopyroxene) provide the best estimates of pre-eruptive sulfur concentrations. These MI generally do not contain sulfides, consistent with their low degrees of post-entrapment modification. Such meltcognate MI in our dataset contain 400-1390 ppm S (median $920 \mathrm{ppm} \mathrm{S}, n=32$ ). However, a number of these MI are in thin sections or bulk grain mounts, and therefore it is uncertain whether these MI were fully sealed inclusions or are sectioned RE, which might have partially degassed during eruption. To avoid this uncertainty, we focus on $13 \mathrm{MI}$ in 
low-Fo olivine and plagioclase hosts, principally from the late May basaltic pumice, which were individually intersected to ensure that MI were fully enclosed. These MI contain an average of $1110 \pm 60 \mathrm{ppm} \mathrm{S}$ (2 standard errors [2 SE]), which we take to be the best approximation of the pre-eruptive sulfur concentrations in F8 phase 3 melts.

\section{Causes of sulfur variation in LERZ melts}

Sulfur concentrations in LERZ MI and matrix are highly variable. Basaltic MI in F8 phase 3 samples have glass-only sulfur concentrations of 310-1320 ppm (not sulfide-restored, $n=80$ ). Melt inclusions and interstitial glasses in evolved phase 1 basalts contain up to $2000 \mathrm{ppm} \mathrm{S}$, which is greater than estimated sulfur concentrations of primary Kîlauea melts (1390-1600 ppm; Clague et al. 1995; Sides et al. 2014b; Rowe et al. 2015). Fissure 17 andesitic melts have low sulfur (220-590 ppm) but contain abundant groundmass sulfides (Fig. 2). Here we discuss the roles of sulfide saturation, fractional crystallization, and degassing in producing the wide range of observed sulfur concentrations in Kīlauea glasses.

Sulfur degassing from Kîlauea melts is expected to be minimal at depths greater than $200 \mathrm{~m}$ (see discussion below). Consequently, sulfur remains largely dissolved in melt during Kīlauea magma storage. Sulfur behaves incompatibly during melt cooling and crystallization, increasing until SCSS ${ }^{\mathrm{T}}$ is reached (Fig. 4c). Down-temperature sulfide saturation is apparent in low-temperature phase 1 basalts and fissure 17 andesites, which contain abundant sulfides in the groundmass and as inclusions within silicate minerals (Gansecki et al. 2019; this study) (Figs. 2 and S1c).

Sulfides have also been observed in other higher temperature Kīlauea melts $\left(\sim 6-14.5\right.$ wt\% $\left.\mathrm{MgO}, \sim 1130-1300{ }^{\circ} \mathrm{C}\right)$, occurring as inclusions in silicate minerals and within groundmass glasses from the 1959 Kîlauea Iki, 1969-1974 Mauna Ulu, 1955 and 1977 ERZ eruptions, and from some Puna Ridge submarine glasses (Desborough et al. 1968; Moore et al. 1980; Helz and Wright 1992; Clague et al. 1995; Helz et al. 2017; Wieser et al. 2020). In F8 samples, some rare high-Fo olivine from F8 contain inclusions consisting of large sulfides with minor melt and vapor bubbles (Figs. 2a and S1j, 1). Similar textures have been observed in olivine from the 1969 Mauna Ulu eruption (Wieser et al. 2020). These large sulfides coexisting with small masses of trapped melts require that the sulfides were included as a separate immiscible melt phase (Wieser et al. 2020). Such sulfide-bearing inclusions generally occur as trains of small inclusions throughout the grain, indicating olivine crystallization in the presence of abundant sulfide globules. Some olivine grains with these types of sulfide inclusions have compositions $\geq \mathrm{Fo}_{86}$, indicating olivine crystallization in sulfide-saturated melts at $\geq 1220^{\circ} \mathrm{C}$. These high temperature melts would have $\operatorname{SCSS}^{\mathrm{T}}$ values $>1400 \mathrm{ppm} \mathrm{S}$ (at $0.2 \mathrm{~S}^{6+} / \Sigma \mathrm{S}$ ) (Fig. 4c), which is similar to estimates of $1390-1600 \mathrm{ppm} S$ in primary
Kīlauea melts (Clague et al. 1995; Edmonds et al. 2013; Sides et al. 2014b; Rowe et al. 2015). If such high sulfur contents of primary Kīlauea melts were typical, magmas derived from closed-system cooling (i.e., cooling without sulfur-degassing) should become sulfide-saturated upon reaching 10-14 wt $\%$ $\mathrm{MgO}\left(\sim 1215-1300^{\circ} \mathrm{C}\right)$ (Wieser et al. 2020).

However, despite LERZ F8 melts containing 6-7 wt\% $\mathrm{MgO}$ and occurring in a local minimum of the down-temperature $\mathrm{SCSS}^{\mathrm{T}}$ trend (Fig. 4c), no sulfides were observed in F8 matrix glasses (Gansecki et al. 2019; P. Wieser, University of Cambridge, written communication; this study). It is possible that groundmass sulfides are absent because they broke down during magma ascent and sulfur degassing (Wieser et al. 2020). However, we do not observe sulfide inclusions in silicate phases that are cognate to the carrier melt, and our estimated pre-eruptive sulfur concentration in F8 melts is $\sim 1110 \mathrm{ppm} \mathrm{S}$, which is slightly below the calculated $\mathrm{SCSS}^{\mathrm{T}}$ for the melt composition and eruption temperature $\left(\mathrm{SCSS}^{\mathrm{T}} \sim 1170-1260 \mathrm{ppm} \mathrm{S}\right.$ at $1140-1150{ }^{\circ} \mathrm{C}$; Fig. $5 \mathrm{c}$ ). These observations indicate that sulfur was previously lost from F8 source melts, otherwise sulfide saturation should have occurred during cooling and crystallization. This conclusion has important implications for the sulfur budget of the LERZ eruption and for the dynamics of the Kîlauea magmatic system, which we discuss further below.

\section{Post-entrapment effects on sulfide saturation in melt inclusions}

The residence of high-Fo olivine grains in lower temperature melts affects MI sulfide saturation in the following ways: (1) MI cooling decreases $\operatorname{SCSS}^{\mathrm{T}}$, (2) diffusive Fe-loss into the host grain during PEC decreases $\operatorname{SCSS}^{\mathrm{T}}$, (3) PEC and Fe-loss causes olivine-incompatible elements to increase in the MI, enriching sulfur toward SCSS ${ }^{\mathrm{T}}$ levels, and (4) redox equilibration of MI with the external melt can either increase or decrease $\mathrm{SCSS}^{\mathrm{T}}$ in the MI, depending on the relative melt conditions (Gaetani et al. 2012; Bucholz et al. 2013; Hartley et al. 2017; Lerner 2020). Fissure $8 \mathrm{MI}$ within high-Fo olivine underwent extensive PEC and Fe-loss (Wieser et al. 2021; this study), which caused sulfur enrichments of $15-54 \%$ in the residual MI while simultaneously lowering the $\mathrm{SCSS}^{\mathrm{T}}$ due to decreasing $\mathrm{MI} \mathrm{FeO}^{\mathrm{T}}$ (from $~ 11.5 \mathrm{wt} \% \mathrm{FeO}^{\mathrm{T}}$ down to 4-6 wt $\% \mathrm{FeO}^{\mathrm{T}}$ ) (Fig. 5c). Additionally, Lerner (2020) shows that the $f \mathrm{O}_{2}$ of many LERZ MI decreased during proximal lava flow transport due to redox equilibration with the external melt, which was undergoing redox reduction via $\mathrm{SO}_{2}$ degassing. All of these factors contributed to the majority of MI in $\mathrm{Fo}_{84-89}$ olivine becoming sulfide-saturated during pre- and syn-eruptive residence in F8 magmas (Figs. 2c, $d$ and 5, and schematically illustrated in Fig. S9).

Similar observations have been made in olivine-hosted MI from the Laki eruption of Iceland, which became 
sulfide-saturated through a combination of cooling, PEC, and $\mathrm{MI}$ reduction of $\sim 1.2 \log$ units $\mathrm{fO}_{2}$ due to MI equilibration with a reduced external melt (Hartley et al. 2017). These phenomena underscore the importance of careful petrography during MI identification and preparation, as accurately determining total sulfur in PEC-affected MI requires detailed measurements of the sizes of the MI, sulfide globules, vapor bubbles, and any daughter minerals (e.g., Cr-spinel) within MI. This contextual information is generally lost for MI analyzed in thin sections or in randomly sectioned bulk grain mounts, and the measured sulfur concentrations in MI glasses could substantially underestimate total sulfur if precipitated sulfides are not accounted for.

Interestingly, sulfur concentrations are highly variable even in high-Fo MI from F8 that have been carefully screened and corrected for sulfides (330-1210 ppm range; $730 \pm 260$, avg. \pm 1 s.d., $n=27$ ). Most high-Fo MI are more sulfur-poor than melt-cognate MI in clinopyroxene, plagioclase, and lower-Fo olivine grains (Fig. 7). Even when considering the large uncertainties in sulfide restorations $( \pm 5 \%$ to $\pm 52 \%$ relative, $2 \sigma)$, the low sulfide-restored sulfur concentrations of $\mathrm{MI}$ in many high-Fo olivine indicate that they must have formed in high temperature melts that were substantially sulfide-undersaturated (Fig. 4c). For reasons discussed more extensively below, we speculate that the wide range of sulfur in primitive $\mathrm{MI}$ is due to some primitive K̄̄lauea melts having undergone shallow sulfur-degassing and recycling.

\section{Volatile degassing and sulfur-isotopic fractionation}

\section{Kïlauea degassing model}

To model H-C-S degassing at Kīlauea, we adopt the approach of Gerlach (1986), who developed a semi-empirical model of $\mathrm{H}_{2} \mathrm{O}, \mathrm{CO}_{2}$, and sulfur degassing from Kīlauea basalts based on published $\mathrm{H}_{2} \mathrm{O}$ and $\mathrm{CO}_{2}$ solubility models and the observation that sulfur gas species constituted $15 \mathrm{~mol} \%$ of both $\mathrm{CO}_{2}$-rich ("type I") and $\mathrm{CO}_{2}$-poor ("type II") gases emitted at Kīlauea. We update this approach with more recent $\mathrm{H}_{2} \mathrm{O}-\mathrm{CO}_{2}$ solubility data of Dixon et al. (1995) for low-pressure tholeiitic basalts. Primary K̄̄lauea magmas are hypothesized to contain
Fig. 7 PEC-corrected sulfur concentrations of MI in different host compositions. (a) Melt inclusion sulfur concentrations relative to host $\mathrm{Mg \#}$ (olivine, clinopyroxene, and orthopyroxene). (b) Melt inclusion sulfur concentrations relative to host An\# (plagioclase). Symbols with pink outlines are sulfiderestored MI sulfur concentrations $( \pm 1$ SE uncertainties of sulfide-restoration), with vertical tie lines connecting sulfiderestored sulfur concentrations to the glass-only sulfur concentrations. Note: no sulfides were present in MI from the oxidized littoral bomb sample (KE623315F). Analytical uncertainties not shown $( \pm 1 \mathrm{SE})$ are smaller than symbol sizes
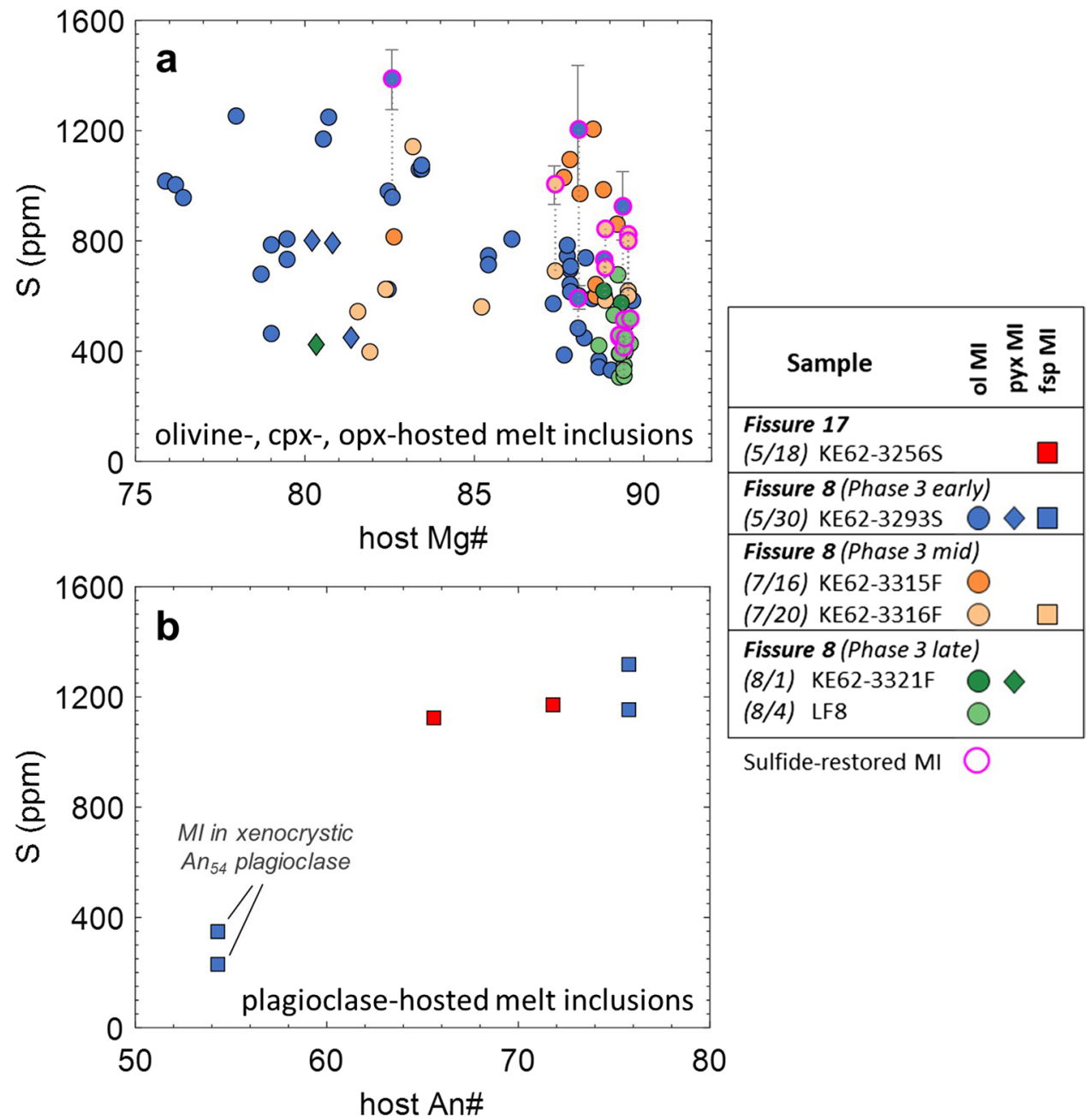
up to $1 \mathrm{wt} \% \mathrm{CO}_{2}$ (Anderson and Poland 2017; Tucker et al. 2019), and the low $\mathrm{CO}_{2}$ solubility in tholeiitic basalts causes rising Kîlauea magmas to be saturated in a $\mathrm{CO}_{2}$-dominated fluid phase throughout nearly the entire crust (Gerlach 1986). Consequently, melts are already largely depleted in $\mathrm{CO}_{2}$ by the time they ascend to the shallow levels of the Kinlauea summit reservoirs. This initial open-system behavior of melts slowly ascending into summit reservoirs gives rise to the $\mathrm{CO}_{2}$-dominated reservoir gases that are continuously degassing from small fumaroles and ground cracks in and around Kīlauea's summit caldera, even during eruptive quiescence (Gerlach and Graeber 1985; Greenland et al. 1985; Gerlach 1986; Gerlach et al. 2002; Elias and Sutton 2007).

The low $\mathrm{H}_{2} \mathrm{O}$ contents of Kîlauea melts prevent substantial $\mathrm{H}_{2} \mathrm{O}$ and sulfur degassing until melts reach very shallow depths (Gerlach 1986; Dixon et al. 1995). A testament to the high solubility of sulfur in Kîlauea melts is that no anomalous $\mathrm{SO}_{2}$ or $\mathrm{H}_{2} \mathrm{~S}$ was detected in the LERZ just one day prior to the onset of the LERZ eruption, even as ascending dikes were causing incipient ground cracking (Clor et al. 2018;
Kern et al. 2020). Closed-system degassing models (assuming initial $\mathrm{H}_{2} \mathrm{O}$ contents of $0.3-0.6 \mathrm{wt} \%$ ) predict that the onset of substantial $\mathrm{H}_{2} \mathrm{O}$ and sulfur degassing does not begin until melts reach 100-200 m beneath the surface (2.2-4.3 MPa) (details in Supplemental Materials). Assuming initial melt volatile concentrations from F8 melt-cognate MI $(\sim 265 \mathrm{ppm}$ $\mathrm{CO}_{2}, 0.3 \mathrm{wt} \% \mathrm{H}_{2} \mathrm{O}$, and $1110 \mathrm{ppm} \mathrm{S}$ ), 80\% of these volatiles would be released in the final $100 \mathrm{~m}$ of magma ascent as a $\mathrm{H}_{2} \mathrm{O}$ - and sulfur-dominated gas (a "type II" gas composition of Gerlach 1986) (Fig. 8). Assuming closed-system degassing during magma ascent from $2.5 \mathrm{~km}$, this model predicts that the melt still retains $0.2 \mathrm{wt} \% \mathrm{H}_{2} \mathrm{O}, 780 \mathrm{ppm} \mathrm{S}$, and $<1 \mathrm{ppm}$ $\mathrm{CO}_{2}$ at a fragmentation depth of $\sim 25 \mathrm{~m}(\sim 0.54 \mathrm{MPa}$; where gas volume/melt volume $\approx 4$ [Sparks 1978; Gerlach 1986]), with molar gas proportions of $0.6 \mathrm{CO}_{2} / \mathrm{SO}_{2}$ and $5.3 \mathrm{H}_{2} \mathrm{O} / \mathrm{SO}_{2}$ (Fig. 8b). Post-fragmentation, ascending melt would undergo open-system degassing of $\mathrm{H}_{2} \mathrm{O}$ and sulfur during lava fountaining and lava flow emplacement. This two-step closed- then open-system degassing model is consistent with the volatile ranges measured in variably degassed matrix glasses from

a

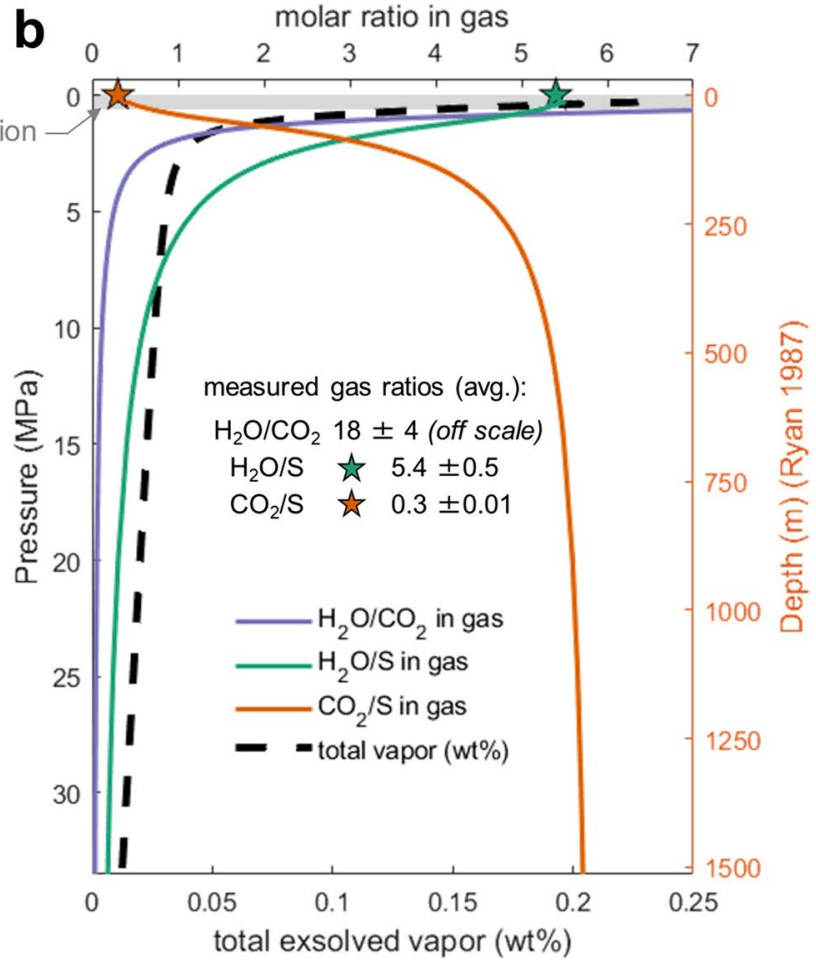

Fig. 8 Closed-system H-C-S degassing model for Kīlauea melt ascent, following Gerlach (1986) and updated to use $\mathrm{H}_{2} \mathrm{O}-\mathrm{CO}_{2}$ solubilities from Dixon et al. (1995). Conditions of pre-eruptive F8 melts are simulated here, with degassing initiating at $2.5 \mathrm{~km}$ depth based on measurements of MI from basaltic pumice erupted from F8 on May 28-30, 2018 ( 265 ppm CO $2,0.3$ wt\% $\left.\mathrm{H}_{2} \mathrm{O}, 1110 \mathrm{ppm} \mathrm{S}\right)$. (a) Modeled $\mathrm{H}_{2} \mathrm{O}, \mathrm{CO}_{2}$, and sulfur remaining in the melt during ascent. Vertical lines indicate the initial modeled volatile concentrations in the melt. Substantial degassing of $\mathrm{H}_{2} \mathrm{O}$ and sulfur occurs at $<100 \mathrm{~m}$ depths. Measured volatile concentrations in F8 basaltic pumice

(KE62-3293S) matrix glasses and melt-cognate MI are shown at top and bottom of panel, respectively. (b) Exsolved vapor mass (wt\% of total melt) and gas molar proportions during melt ascent. Average F8 gas ratios measured by Multi-GAS (Kelly et al. 2021) are shown at top of panel. Note: open-system degassing is likely at depths above the estimated fragmentation level $(\leq 25 \mathrm{~m}$; shaded gray region), but is not included in the model. Depth below the surface is from a depth-density parameterization after Ryan (1987) (see Supplementary Materials). Analytical uncertainties of glass measurements (2 SE) are $\sim 15 \%$ for $\mathrm{H}_{2} \mathrm{O}$ and $\mathrm{CO}_{2}$, and $\sim 10 \%$ for sulfur 
F8 pumice $\left(0.05-0.33\right.$ wt $\% \mathrm{H}_{2} \mathrm{O}, 100-810 \mathrm{ppm} \mathrm{S},<30 \mathrm{ppm}$ $\left.\mathrm{CO}_{2}[\mathrm{bdl}]\right)$.

This same shallow $\mathrm{H}_{2} \mathrm{O}-\mathrm{S}$ degassing regime is applicable for the ascent of all low- $\mathrm{H}_{2} \mathrm{O}$ Killauea melts, including the 2008-2018 Halema'uma'u lava lake (Edmonds et al. 2013; Elias et al. 2020). For example, during the LERZ eruption the rapid decline in $\mathrm{SO}_{2}$ degassing at Kīlauea's summit from $\sim 15 \mathrm{kt} /$ day in mid-May to $\sim 1 \mathrm{kt} /$ day by mid-June (Kern et al. 2020) can be explained by the infilling of the draining Halema'uma'u lava lake with $\geq 100-200 \mathrm{~m}$ of collapse debris, which we hypothesize was sufficient to re-establish 2.1-4.3 MPa of lithostatic pressure and thereby prevent major sulfur and $\mathrm{H}_{2} \mathrm{O}$ degassing.

\section{The effect of $\mathrm{SO}_{2}$ degassing on Kilauea melt $\delta^{34} \mathrm{~S}$}

$\mathrm{SO}_{2}$ degassing from magmas can impart redox and isotopic changes to residual melts. As observed in Kīlauea samples (including $\mathrm{LERZ}$ glasses), $\mathrm{SO}_{2}$ degassing from $\mathrm{S}^{2-}$-dominated melts causes a reduction in melt $f \mathrm{O}_{2}$ (Moussallam et al. 2016; Helz et al. 2017; Lerner 2020). The redox difference between gaseous $\mathrm{SO}_{2}$ and dissolved $\mathrm{S}^{2-}$ in the melt causes the fractionation of sulfur-isotopes during degassing, where the more oxidized $\mathrm{SO}_{2}$ vapor phase is isotopically heavier (Richet et al. 1977; Miyoshi et al. 1984; Marini et al. 2011). At $1150^{\circ} \mathrm{C}, \mathrm{SO}_{2}$ vapor will have $1.5 \%$ o to $2.2 \%$ o higher $\delta^{34} \mathrm{~S}$ than the equilibrium residual melt, depending on the proportion of $\mathrm{S}^{6+}$ in the melt (calculations for 0.2 and $0.0 \mathrm{~S}^{6+} / \Sigma \mathrm{S}$, respectively) (Richet et al. 1977; Miyoshi et al. 1984). Kinetic effects related to the different diffusivities of ${ }^{32} \mathrm{~S}$ and ${ }^{34} \mathrm{~S}$ isotopes and/or $\mathrm{S}^{2-}$ and $\mathrm{S}^{6+}$ melt complexes are thought to be minimal in $1150{ }^{\circ} \mathrm{C}$ basaltic melts (Fiege et al. 2015).

This isotopic fractionation due to $\mathrm{SO}_{2}$ degassing is observed in the positive correlation between measured $\delta^{34} \mathrm{~S}$ and sulfur concentrations in LERZ F8 glasses (Fig. 9b). With the $\delta^{34} \mathrm{~S}$ fractionation factors above, we construct an isotopic degassing model that parameterizes decreasing $\mathrm{S}^{6+} /$ $\Sigma \mathrm{S}$ with sulfur degassing and progressive reduction of the melt (Fig. 9a). We assume the initial melt contains $1100 \mathrm{ppm}$ $\mathrm{S}$ and has a $\delta^{34} \mathrm{~S}$ value of $1.0 \%$. Following the degassing model presented above (Fig. 8), we model closed-system degassing of $\sim 30 \%$ of the initial sulfur, at which point we assume magma fragmentation and fountaining (Sparks 1978; Gerlach 1986). Post-fragmentation, we assume open-system degassing until $90 \%$ of the initial sulfur is degassed. Based on S-XANES measurements that document how $\mathrm{S}^{6+} / \Sigma \mathrm{S}$ decreases with sulfur-loss in LERZ melts (Lerner 2020), we assume 0.2 initial $\mathrm{S}^{6+} / \Sigma \mathrm{S}$ in the melt, which decreases to 0.1 $\mathrm{S}^{6+} / \Sigma \mathrm{S}$ after $30 \%$ sulfur degassing, then to $0.05 \mathrm{~S}^{6+} / \Sigma \mathrm{S}$ after $50 \%$ sulfur degassing, and finally to $0.0 \mathrm{~S}^{6+} / \Sigma \mathrm{S}$ after $70 \%$ sulfur degassing. This two-stage closed- then open-system degassing model matches our observations well: sulfur-rich matrix glass $\delta^{34} \mathrm{~S}$ compositions of $+0.2 \%$ are reproduced at $\sim 40 \%$ sulfur degassing ( $660 \mathrm{ppm} \mathrm{S} \mathrm{remaining} \mathrm{in} \mathrm{the} \mathrm{melt),}$ and sulfur-poor matrix glass compositions of $-2.5 \%$ are reproduced at $82 \%$ total sulfur degassing $(\sim 200 \mathrm{ppm} \mathrm{S} \mathrm{remain-}$ ing in the melt) (Fig. 9a, b). After $82 \%$ sulfur degassing, the cumulative exsolved $\mathrm{SO}_{2}$ gas will be $4.3 \%$ o heavier than the residual degassed melt.

$\delta^{34} \mathrm{~S}$ in Kīlauea samples was also measured by Sakai et al. (1982), who analyzed a range of sublimates, gases, and subaerial and submarine bulk lavas. They observe that subaerially erupted bulk lavas were largely sulfurdegassed and isotopically light, having bulk rock concentrations of $30-180 \mathrm{ppm} \mathrm{S}$ and $\delta^{34} \mathrm{~S}$ values of -2.2 to $+0.4 \%$ o $(-0.8 \pm 0.8 \%$, avg. \pm 1 s.d., $n=12)$. In contrast, submarine lavas from the Puna Ridge were less degassed and were isotopically heavier, having bulk rock sulfur concentrations of $530-840 \mathrm{ppm} \mathrm{S}$ and higher $\delta^{34} \mathrm{~S}$ values of -0.6 to $+0.8 \%$ o $(+0.5 \pm 0.6 \%$, avg. \pm 1 s.d., $n=6)$. Gerlach and Thomas (1986) applied a Rayleigh fractionation model to the Sakai et al. (1982) data and predicted that Kîlauea deep reservoir gases would have an initial $\delta^{34} \mathrm{~S}$ value of $+1.5 \%$. Despite differences in measurement techniques (bulk vs in situ), these past studies are in good agreement with our measured $\delta^{34} \mathrm{~S}$ ranges of sulfur-degassed and undegassed glasses from F8 samples. We therefore conclude that low $\delta^{34} \mathrm{~S}$ values (e.g., $<0 \%$ ) in Kīlauea melts are a robust indicator of sulfur-loss by $\mathrm{SO}_{2}$ degassing.

One anomalous sulfide-bearing MI in a high-Fo olivine from the basaltic pumice falls off this $\delta^{34} \mathrm{~S}$-sulfur concentration trend. This particular $\mathrm{MI}$ also has a very $\mathrm{CO}_{2}$-rich vapor bubble that indicates an entrapment depth of $\sim 7 \mathrm{~km}$, which is the deepest observed in our dataset. This MI is unusual in other ways, in that it has relatively large sulfide for the MI size and the glass has high $S^{6+} / \Sigma S(\sim 0.25)$ despite a relatively low calculated $f \mathrm{O}_{2}$ (FMQ - 0.3; Lerner 2020). In addition, one plagioclase-hosted $\left(\mathrm{An}_{54}\right)$ MI has anomalously high $\delta^{34} \mathrm{~S}$ for its low sulfur concentration (+1\%o, $400 \mathrm{ppm} \mathrm{S})$. This MI has an andesitic composition and is likely a xenocrystic sample from an evolved magma pod within the LERZ. Gradual cooling and crystallization during long-term LERZ storage may have caused this melt to have lost sulfur by sulfide saturation rather than by $\mathrm{SO}_{2}$ degassing. The lack of $\delta^{34} \mathrm{~S}$ fractionation during sulfide saturation at Killauea temperatures and $f \mathrm{O}_{2}$ conditions may explain why this evolved MI retains a similar $\delta^{34} \mathrm{~S}$ signature as sulfur-rich basaltic LERZ glasses.

Apart from these outliers, the relationship between sulfur concentration and $\delta^{34} \mathrm{~S}$ is robust in LERZ matrix glasses and MI. Many MI in high-Fo olivine have low $\delta^{34} \mathrm{~S}$ values and low sulfur concentrations, which both indicate that these melts had lost sulfur by $\mathrm{SO}_{2}$ degassing prior to $\mathrm{MI}$ entrapment. Because significant $\mathrm{SO}_{2}$ degassing at Kīlauea only occurs at very shallow depths, these sulfur-degassed, high-Fo bearing primitive melts must have experienced nearsurface pressures prior to MI formation. 

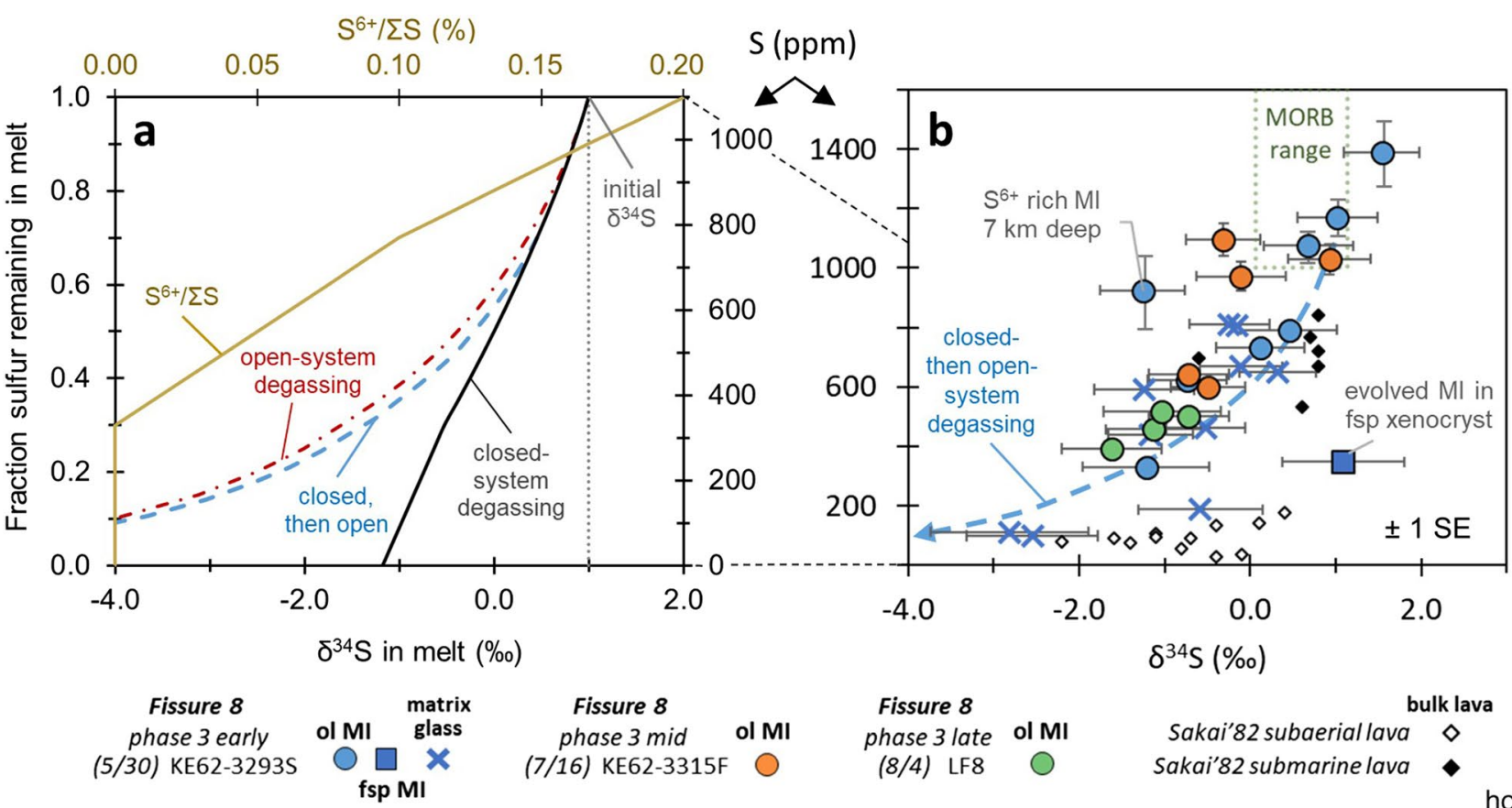

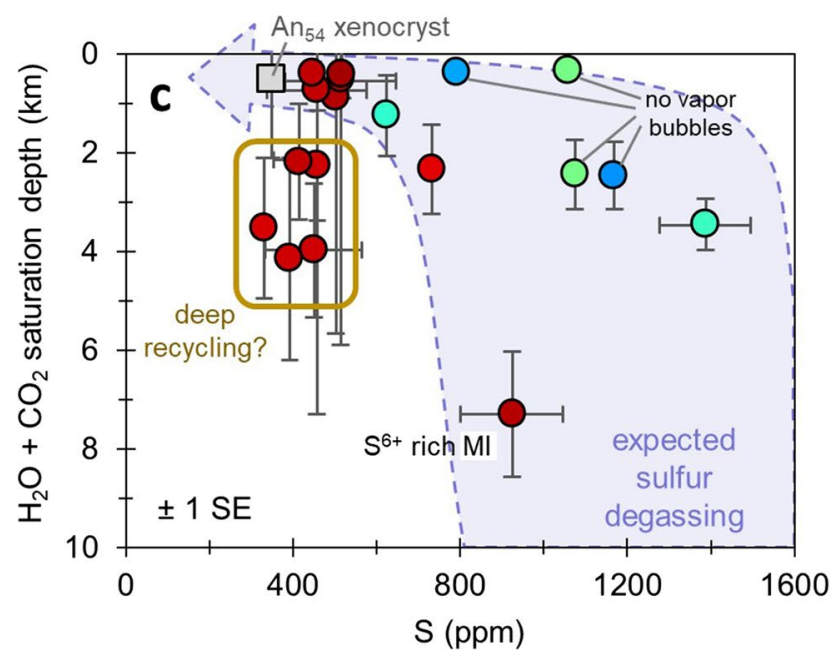

Fig. 9 (a) Closed- (black) and open-system (red) degassing models from the assumed LERZ F8 pre-eruptive sulfur concentrations and $\delta^{34} \mathrm{~S}$ values. A mixed closed-open system degassing model (blue) assumes a change from closed- to open-system behavior at the point of fragmentation ( $\sim 75 \%$ total $\mathrm{H}-\mathrm{C}-\mathrm{S}$ gas exsolution, where $30 \%$ the of initial sulfur has degassed). All models include a decreasing $\mathrm{S}^{6+} /$ $\Sigma \mathrm{S}$ proportion in the melt during degassing (yellow), based on observations from S-XANES measurements (Lerner 2020). (b) $\delta^{34} S$ and sulfur concentrations in matrix glasses and MI from F8 samples. The blue curve is the mixed closed- then open-system degassing path from panel (a). Degassed subaerial and sulfur-rich submarine bulk

\section{Volatile budgets of the 2018 LERZ eruption}

\section{Petrologically derived LERZ gas emissions}

Maximum $\mathrm{SO}_{2}$ emission rates from LERZ fissures reached $600 \mathrm{kt} / \mathrm{day}$, and sustained emission rates $\geq 100 \mathrm{kt} / \mathrm{day}$

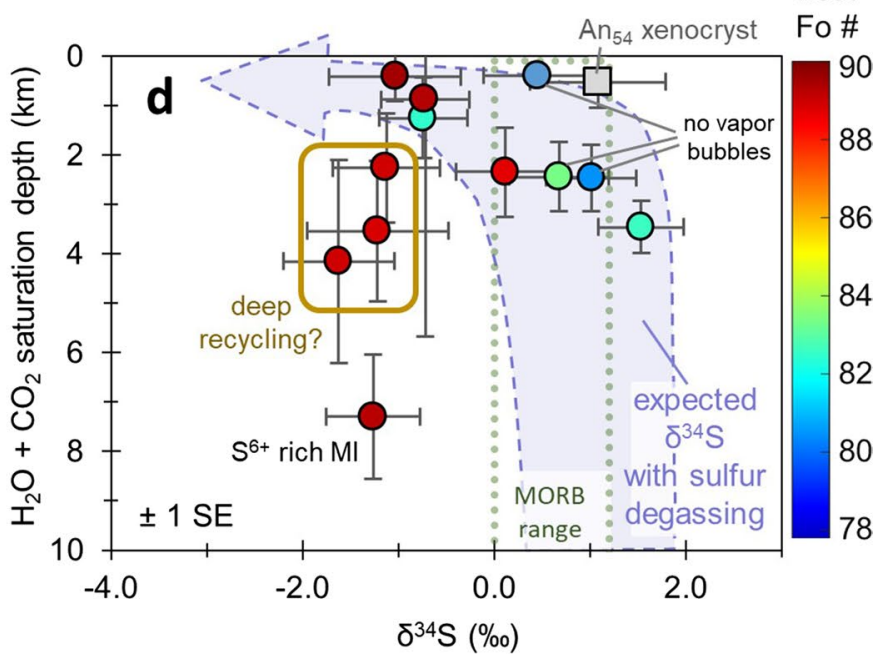

lava analyses of Sakai et al. (1982) are shown as smaller open and closed symbols. The sulfur concentration and $\delta^{34} \mathrm{~S}$ ranges of MORB are shown for comparison. (c) Entrapment depth vs sulfur concentrations in F8 MI. Major sulfur loss from degassing should not occur until near surface pressures (schematically shown). (d) Entrapment depth vs $\delta^{34} \mathrm{~S}$ in F8 MI. $\delta^{34} \mathrm{~S}$ fractionation occurs during sulfur degassing at shallow depths (schematically shown). Samples in (c) and (d) are from KE62-3293S and LF8, and are colored by host-olivine Fo number. Sulfur concentrations in all MI have been sulfide-restored, where applicable, and PEC-corrected. Analytical uncertainties not shown $( \pm 1 \mathrm{SE})$ are smaller than symbol sizes

occurred throughout most of June and July (Kern et al. 2020). These $\mathrm{SO}_{2}$ emission rates dwarfed the average $\sim 4.5$ $\mathrm{kt} /$ day $\mathrm{SO}_{2}$ emitted from the Halema'uma'u lava lake during the 2008-2018 activity (Beirle et al. 2014; Elias et al. 2018a, 2020). The cumulative $\mathrm{SO}_{2}$ emissions for the 3-month long 2018 eruption are estimated to be $10.2 \mathrm{Mt}(7.1-13.6 \mathrm{Mt}$ at a 
$68 \%$ confidence interval $[1 \sigma])$, making the LERZ eruption one of the largest $\mathrm{SO}_{2}$-emitting events of the last century (Kern et al. 2020). Applying the "petrologic method" to estimate erupted lava volumes (e.g., Rose 1977; Devine et al. 1984; Thordarson et al. 1996; Sharma et al. 2004; Harris et al. 2007), Kern et al. (2020) use the cumulative $\mathrm{SO}_{2}$ emissions and an estimated melt $\operatorname{SCSS}^{\mathrm{T}}$ concentration $(1250 \mathrm{ppm}$ S) to calculate DRE erupted lava volumes of $\sim 1.7 \pm 0.6 \mathrm{~km}^{3}$ $(1 \sigma)$. This sulfur-based estimation of erupted lava volume is valuable for understanding the scale of the 2018 LERZ eruption because substantial offshore lava emplacement (Soule et al. 2021) leaves volume estimates imperfectly constrained.

Our MI-derived estimate of pre-eruptive sulfur concentrations of F8 melts is $\sim 1110 \mathrm{ppm} \mathrm{S}$, which is lower than the sulfide-saturated estimate of $1250 \mathrm{ppm} \mathrm{S}$ assumed by Kern et al. (2020). This refined pre-eruptive sulfur estimate proportionately increases the required erupted DRE lava volume to $1.9 \pm 0.6 \mathrm{~km}^{3}( \pm 1 \sigma)$ to account for the cumulative $10.2 \pm 3.2 \mathrm{Mt}$ of emitted $\mathrm{SO}_{2}( \pm 1 \sigma)$. Scaling this DRE lava volume with our petrologic estimates of pre-eruptive $\mathrm{H}_{2} \mathrm{O}$ and $\mathrm{CO}_{2}$ in $\mathrm{F} 8$ melts $\left(\sim 0.3\right.$ wt $\% \mathrm{H}_{2} \mathrm{O}$ and $265 \mathrm{ppm} \mathrm{CO}_{2}$ in late May) we calculate cumulative emissions of $10-18 \mathrm{Mt}$
$\mathrm{H}_{2} \mathrm{O}$ and 0.9-1.7 $\mathrm{Mt} \mathrm{CO}_{2}(2 \sigma)$ from the LERZ fissures. In comparison, Kern et al. (2020) estimated 11-21 $\mathrm{Mt} \mathrm{H}_{2} \mathrm{O}$ and 1.5-2.8 $\mathrm{Mt} \mathrm{CO}_{2}(2 \sigma)$ by scaling total $\mathrm{SO}_{2}$ emissions with gas ratios measured in situ at F8 (Kelly et al. 2021). Given the extensive $\mathrm{CO}_{2}$ loss from Kîlauea melts during crustal ascent (Gerlach 1986; Anderson and Poland 2017), $\mathrm{CO}_{2}$ degassing from the LERZ fissures themselves may only represent $2-5 \%$ of the total $\mathrm{CO}_{2}$ emitted from the primary magmas that ultimately sourced the LERZ eruption (see Supplementary Materials for further discussion on petrologic method calculations and comparisons with measured gas ratios). Despite the large uncertainties in $\mathrm{SO}_{2}$ emission rates, lava effusion rates, and pre-eruptive sulfur concentrations of LERZ melts, we share the conclusion of Kern et al. (2020) and Dietterich et al. (2021) that substantially more lava erupted from the LERZ fissures than the $0.8 \mathrm{~km}^{3}$ summit caldera collapse volume would account for.

Additionally, we calculate the time series of expected $\mathrm{SO}_{2}$ emissions based on lava effusion volumes from lava flow mapping and UAS videos of the F8 lava channel by Dietterich et al. (2021) (Fig. 10; details in Supplementary Materials). Despite substantial petrologic uncertainties (e.g.,

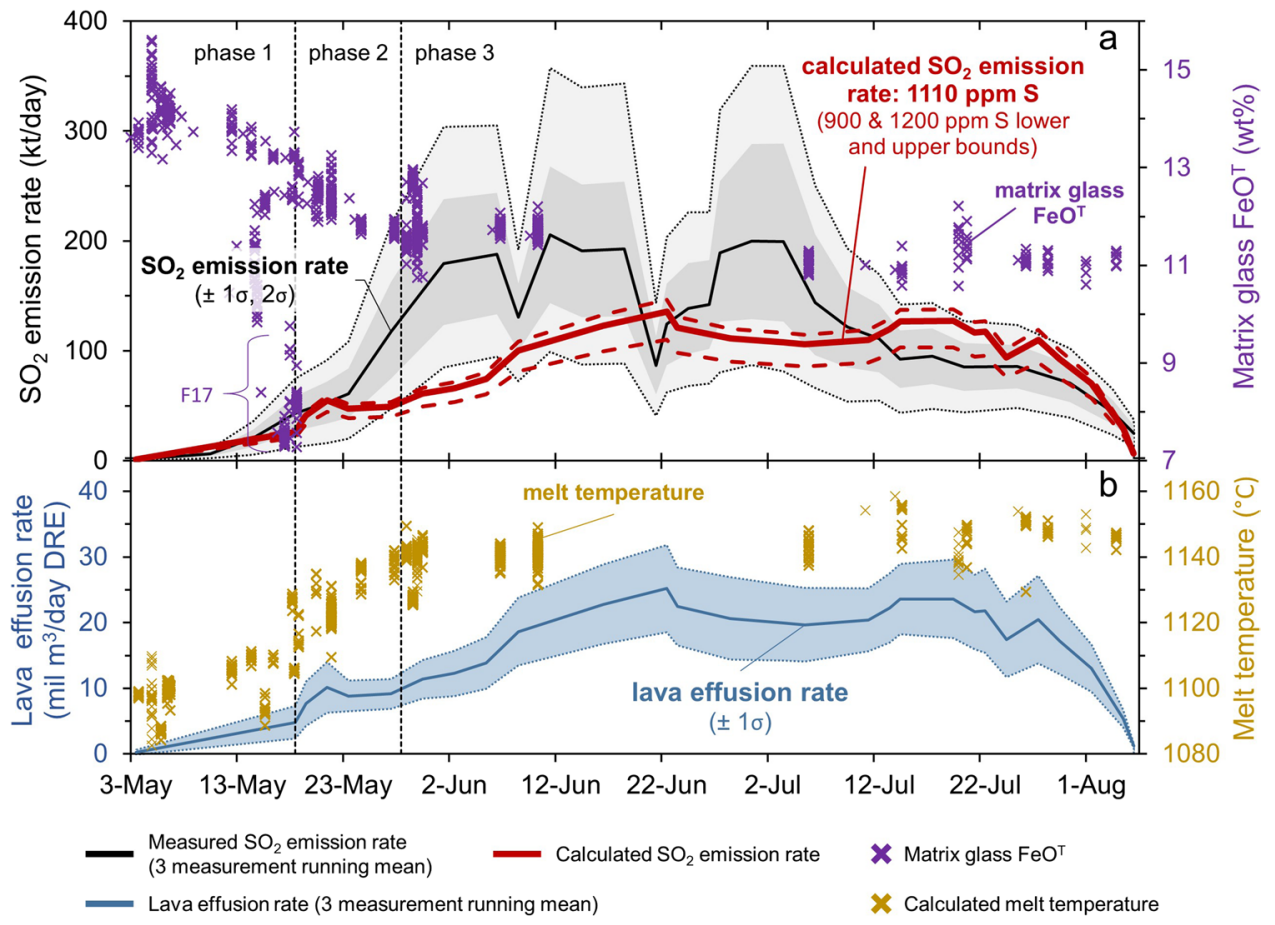

Fig. 10 (a) Time series of measured $\mathrm{SO}_{2}$ emission rates (black line with shaded bounds for 68 and $95 \%$ confidence bounds; Kern et al. 2020) and $\mathrm{FeO}^{\mathrm{T}}$ concentrations in proximally quenched matrix glasses (purple crosses) during the 2018 LERZ eruption. (b) Time series of DRE lava effusion rates in million $\mathrm{m}^{3} /$ day (blue line with shaded bounds for $\pm 1 \sigma$ propagated uncertainties; Dietterich et al. 2021) and calculated melt temperature from matrix glass Mg-thermometry (gold crosses). $\mathrm{SO}_{2}$ emission rates and lava effusion rates are 3-measurement running means. (a) Petrologically calculated $\mathrm{SO}_{2}$ emission rates (red lines) are based on lava effusion rates and melt sulfur concentrations; the solid line assumes a pre-eruptive melt concentration of $1110 \mathrm{ppm} \mathrm{S}$ and the dashed lines assume lower and upper bounds of 900 and 1200 ppm S. Fissure 17 (F17) eruptive melt temperatures of $1030-1070{ }^{\circ} \mathrm{C}$ are off-scale in (b). The LERZ eruption formally ended on September 5; however, $\mathrm{SO}_{2}$ emissions and lava effusion after August 5 were negligible and are not shown here. Matrix glass compositions are from Lee et al. (2019), T. Shea (unpublished data), and this study 
temporal variability of pre-eruptive melt sulfur and magma crystal fraction) and large uncertainties in both estimated lava effusion rates $( \pm 30 \%, 1 \sigma)$ and $\mathrm{SO}_{2}$ emission rates, the petrologically reconstructed time series of $\mathrm{SO}_{2}$ emissions using a constant $1110 \mathrm{ppm} \mathrm{S}$ melt concentration agrees fairly well with observed degassing rates (Fig. 10).

However, there are two time periods where the petrologic estimates diverge from observed degassing. In late May to mid-June, petrologic estimates of $\mathrm{SO}_{2}$ emission rates are notably lower than observed values. If we assume that measured $\mathrm{SO}_{2}$ emission rates and lava effusion rates are accurate, then the LERZ melts would need to contain > 2000 ppm S to account for the late May to mid-June $\mathrm{SO}_{2}$ emission rates. Yet, F8 melts erupting during this time had $\mathrm{FeO}^{\mathrm{T}}(11-13$ wt $\%)$ and melt temperatures $\left(\sim 1140{ }^{\circ} \mathrm{C}\right)$ that indicate that melt SCSS ${ }^{\mathrm{T}}$ was $\sim 1200-1300 \mathrm{ppm} \mathrm{S}$, similar to the rest of phase 3 melts (Figs. $4 \mathrm{c}$ and $5 \mathrm{c}$ ). If the melt was sulfide-saturated at these $\mathrm{SCSS}^{\mathrm{T}}$ values, the elevated $\mathrm{SO}_{2}$ emissions in late May to mid-June would require $0.1-0.3$ volume percent sulfides to have been present in the bubble-free melt and to have completely broken down to add to the $\mathrm{SO}_{2}$ emissions. Sulfide breakdown during ascent and degassing has been suggested to play a large role in sulfur degassing from some Kîlauea eruptions (Edmonds et al. 2018; Wieser et al. 2020); however, we do not observe residual sulfides in any F8 matrix glasses nor as inclusions in minerals cognate to the F8 melts. Consequently, we consider it unlikely that such a substantial sulfide load was present in the late May to midJune F8 melts. Rather, we find it more probable that either the lava effusion rates were underestimated and/or that $\mathrm{SO}_{2}$ emission rates were overestimated during this period. The possible role of sulfides in F8 melts could be better informed by detailed petrographic surveys and chalcophile trace element measurements throughout the eruption (e.g., Edmonds et al. 2018; Wieser et al. 2020).

In mid- to late July the petrologic estimates are slightly overestimated compared to the observed $\mathrm{SO}_{2}$ emissions. Assuming that lava effusion rates are correct, the preeruptive LERZ melt would need to contain 700-900 ppm $\mathrm{S}$ during this time to bring the petrologic estimates into accord with observed $\mathrm{SO}_{2}$ emissions. Matrix glasses erupted in early August have pre-eruptive sulfur concentrations estimated from their chlorine contents (see Supplementary Materials) of 750-950 ppm S, which would be consistent with the reduced $\mathrm{SO}_{2}$ measurements toward the end of the eruption. Interestingly, the lavas erupted during this time included many high-Fo olivine phenocrysts and were $\sim 10^{\circ} \mathrm{C}$ hotter than earlier erupted lavas (Gansecki et al. 2019; Mourey et al. 2019; this study) (Figs. 3 and 10b). Despite their primitive compositions, many MI in these high-Fo olivine have both low sulfur concentrations (sulfide-restored) and isotopically-light, degassed $\delta^{34} \mathrm{~S}$ signatures. We speculate that previously degassed primitive melts containing these high-Fo olivine became increasingly mixed into the LERZ magma toward the end of the eruption, explaining why hotter, late phase 3 melts were more sulfur-depleted than cooler, earlier erupted phase 3 melts.

\section{Quantifying degassing from the fissure 8 vent vs the lava channel}

The prodigious $\mathrm{SO}_{2}$ degassing during the LERZ eruption was dominantly sourced from degassing at the F8 cinder cone, but substantial $\mathrm{SO}_{2}$ was also measured downwind from the highly active F8 lava channel. During subaerial eruptions, the exsolution of $\mathrm{H}_{2} \mathrm{O}$ and other volatiles should cause most sulfur to enter the vapor and degas (Gerlach 1986; Wallace and Carmichael 1992). However, we observe a range of $\sim 150-900$ ppm S measured in matrix glasses and RE from the rapidly quenched basaltic pumice samples (Fig. 11). Sulfur concentrations in matrix glasses and $\mathrm{RE}$ have a clear dependence on the proximity of the glass to nearby vesicles (Fig. 11b), with the caveat that this is a 2-dimensional observation for a 3-dimensional phenomenon. The elevated sulfur in subaerially erupted matrix glasses and $\mathrm{RE}$ interiors is evidence of disequilibrium degassing resulting from the relatively low diffusivity of sulfur $\left(\sim 10^{-12} \mathrm{~m}^{2} / \mathrm{s}\right.$ at $1150{ }^{\circ} \mathrm{C}$; Behrens and Stelling 2011) and of incomplete degassing of $\mathrm{H}_{2} \mathrm{O}$ and other species, which limits sulfur partitioning (Wallace and Carmichael 1992). Unsurprisingly, matrix glasses in samples from more distal locations in the lava channel have lower sulfur contents. Matrix glasses in the littoral blast sample, which traveled the full 13-km lava channel prior to quenching, are essentially completely sulfur-degassed (Figs. 11b and S11). Assuming pre-eruptive sulfur concentrations of $1110 \mathrm{ppm} \mathrm{S}$, the observed range of 100-500 ppm S remaining in the basaltic pumice matrix glass shows that $\sim 55-90 \%$ of the magmatic sulfur was degassed during ascent and eruption at F8, whereas 10-45\% of sulfur remained in the lava and degassed during surface flow (Fig. 11b). These estimated proportions of sulfur degassing from the F8 fissure vs the lava flow are supported by measurements of $\mathrm{SO}_{2}$ emissions made during rare days of easterly winds, which allowed the F8 "fountain gas" and "channel gas" plumes to be spatially resolvable (Fig. S14a, b). On four separate days in June, $\mathrm{SO}_{2}$ degassing from the lava channel accounted for an average of $36 \pm 11 \%$ (1 s.d.) of the total $\mathrm{SO}_{2}$ emissions from the LERZ eruption (Fig. S14c). Estimates of bulk lava densities in the proximal lava channel were as low as $500-1300 \mathrm{~kg} / \mathrm{m}^{3}$, requiring that the proximal lava channel contained $50-82 \%$ vesicles by volume (Patrick et al. 2019c), which is consistent with substantial degassing of sulfur and $\mathrm{H}_{2} \mathrm{O}$ occurring from the lava channel.

Our observations of incomplete sulfur degassing within the F8 lava fountains indicate that $1.0-4.6 \mathrm{Mt}$ of the total 



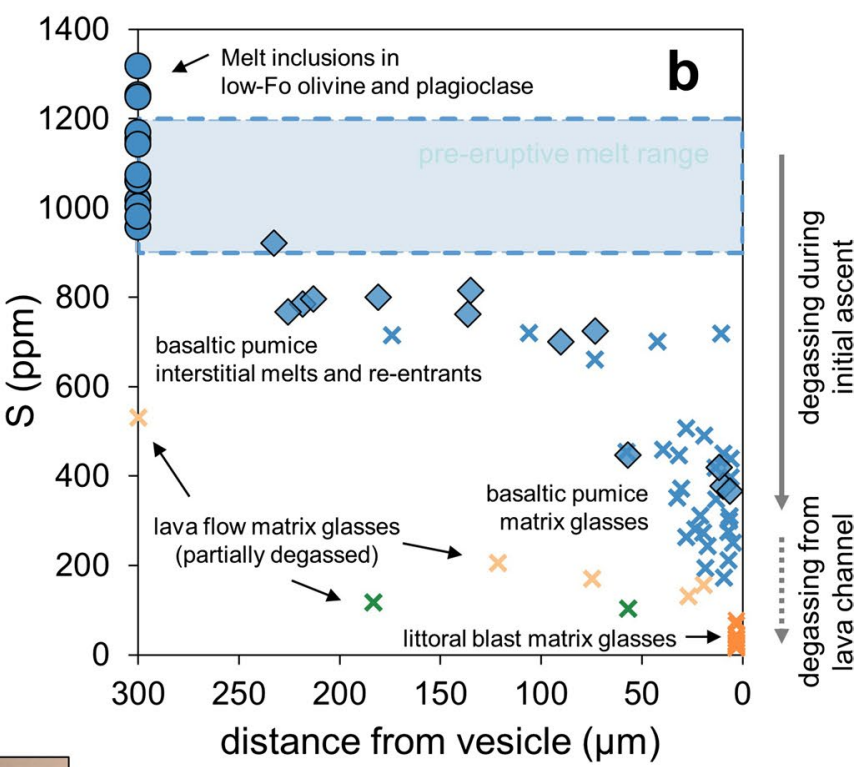

Fissure 8 cognate melt inclusions

$(5 / 30,7 / 16) \mathrm{Ml}$ in low-Fo olivine and plagioclase

Fissure 8 matrix glasses

(5/30) KE62-3293S Basaltic pumice re-entrants KE62-3293S Basaltic pumice matrix glass

(7/16) KE62-3315F Littoral blast matrix glass

(7/20) KE62-3316F Lava flow matrix glass

(8/01) KE62-3321F Lava flow matrix glass
Fig. 11 (a) Melt re-entrant channel (RE) within an olivine from the basaltic pumice, showing a decrease in sulfur concentration from the RE interior to the mouth. (b) Sulfur concentration measured in matrix glasses (blue crosses) and RE (blue diamonds) from rapidly quenched basaltic pumice compared to the distance from the nearest vesicle. The rapidly quenched matrix glasses have lost $\sim 55-90 \%$ of initial sulfur, compared to F8 melt inclusions (MI) in low-Fo olivine and plagioclase grains (blue circles) that provide the best estimate of pre-eruptive melt sulfur concentrations. Matrix glasses from the littoral blast sample (orange crosses) have completely degassed sulfur during prolonged lava channel transit. The analytical sulfur detection limit (95\% confidence) is $\sim 40 \mathrm{ppm}$ and analytical uncertainties $( \pm 1$ $\mathrm{SE}$ ) are roughly equal to symbol sizes. (c) The effect of prolonged $\mathrm{SO}_{2}$ degassing from the lava channel is apparent in downwind vegetation die-offs. Photo by L. DeSmither, U.S. Geological Survey

blown to ground level by moderate winds. The prevailing northeasterly trade winds caused the regions to the SSW of the main LERZ lava channel to be frequently inundated by hazardous levels of $\mathrm{SO}_{2}$. The impact of these acidic gases on the downwind vegetation was obvious, causing widespread foliage damage and presenting a locally severe health hazard (Fig. 11c).

Compared to sulfur, chlorine is more soluble and diffuses more quickly in basaltic melts (Baker and BalconeBoissard 2009). Chlorine concentrations do not exhibit 
gradients within RE or in matrix glasses approaching vesicles (Fig. S13). Chlorine and $\mathrm{K}_{2} \mathrm{O}$ concentrations in matrix glasses of distally quenched lavas are higher than in proximally quenched glasses, indicating net chlorine enrichment during groundmass crystallization (Figs. S11 and S16) (see discussion in Supplemental Material).

\section{Petrologic insights into the Kilauea plumbing system from LERZ magmas}

\section{Fissure 8 magma sources}

The relatively shallow entrapment depths of MI from the LERZ eruption (Wieser et al. 2021; this study) and numerous earlier Kīlauea eruptions (Anderson and Brown 1993; Moore et al. 2015; Tuohy et al. 2016; Wallace 2018) provide insights into the structure of Kîlauea's upper reservoir systems. Lower-Fo olivine from F8 phase 3 magmas crystallized at depths $\leq 3 \mathrm{~km}$ (Wieser et al. 2021; this study), consistent with origins in the geophysically determined Halema' uma'u reservoir (1-3 km depth beneath the summit; Fig. S18) (Poland et al. 2014; Anderson et al. 2019). Low-Fo olivine $\left(<\mathrm{Fo}_{83}\right)$ were part of the equilibrium mineral assemblage ( \pm plagioclase \pm clinopyroxene) of the $1140-1150{ }^{\circ} \mathrm{C}$ F8 phase 3 magmas, and thus the shallow crystallization depths of these minerals likely represent the storage conditions for the majority of LERZ phase 3 magmas.

Many high-Fo olivine $\left(\geq \mathrm{Fo}_{86}\right)$ from F8 magmas crystallized at depths of 3-5 km (Wieser et al. 2021; this study), which is consistent with origins in the geophysically inferred South Caldera reservoir (Cervelli and Miklius 2003; Poland et al. 2014) (Fig. S18). These high-Fo olivine formed in magmas $\geq 1200{ }^{\circ} \mathrm{C}$ and are in obvious disequilibrium with the cooler bulk F8 carrier melt, indicating that these deeper storage conditions represent only a subsidiary portion of the total phase 3 magmas. Interestingly, a substantial number of MI in high-Fo olivine have shallower entrapment depths of $<1-2 \mathrm{~km}$ (Wieser et al. 2021; this study), indicating that some high-temperature primitive Kîlauea magmas ascended and trapped MI at near-surface depths (discussed below).

Increased seismicity at 5-13 km depths was observed some months prior to the LERZ eruption (Flinders et al. 2020; Mourey et al. 2019). However, the $\sim 1-5 \mathrm{~km}$ entrapment depths of most $\mathrm{MI}$ in high-Fo olivine from F8 are inconsistent with origins in such deep magmas. We therefore consider the upward transport of high-Fo crystals from deep crystal accumulation storage zones into shallower reservoirs to be of lesser importance in the LERZ eruption compared to the 1959 Killauea Iki and 1960 Kapoho eruptions, which both contained numerous MI with entrapment depths of 6 to $>10 \mathrm{~km}$ (Moore et al. 2015; Tuohy et al. 2016) (Fig. 6b). During the LERZ eruption, shallowly stored primitive magma containing high-Fo olivine became mixed with lower temperature melts during transport within the summit and along the ERZ, resulting in the hybridized $1140-1150{ }^{\circ} \mathrm{C}$ phase $3 \mathrm{LERZ}$ melts that erupted from $\mathrm{F} 8$ (Fig. 12). High-Fo olivine grains in F8 lavas have a range of low-Fo rim thicknesses, including many with relatively thin rims that indicate entrainment within cooler magma not long before eruption (Mourey et al. 2019; this study). One explanation for the pre-eruptive preservation of the thin-rimmed high-Fo olivine in LERZ magmas is that these crystals were stored in relatively shallow, high-temperature $\left(1250-1300^{\circ} \mathrm{C}\right)$ melt pods within the summit reservoir network until shortly before eruption. Alternatively, the high-Fo olivine may have crystallized from older magmas and have been preserved for longer durations within cumulate piles (Wieser et al. 2019, 2021), where the low interstitial melt fraction limited diffusive re-equilibration with lowertemperature melts (e.g., Thomson and Maclennan 2013).

One analysis of interstitial matrix glass from the rapidly quenched basaltic pumice, which experienced limited degassing because of surrounding crystals, had measurable $\mathrm{CO}_{2}(\sim 220 \mathrm{ppm})$ and a calculated vapor saturation depth of $2.2 \pm 0.6 \mathrm{~km}$. This provides a constraint on the shallowest depth that melts traveling from the summit region to the LERZ could have attained, which is consistent with seismicity and deformation modeling of the down-rift dike propagation from $\mathrm{Pu}^{6} \mathrm{u}^{6} \bar{o}^{`} \overline{\mathrm{o}}$ (Neal et al. 2019). Lastly, vapor bubble $\mathrm{CO}_{2}$ in a single clinopyroxene-hosted MI from fissure 9 gives an entrapment depth of $3.8 \pm 2.0 \mathrm{~km}$. This depth is consistent with pre-eruptive seismicity in the LERZ (Neal et al. 2019) and provides a rough estimate on storage depths of phase 1 evolved magma bodies in the LERZ.

In summary, we have roughly constrained pre-eruptive $\mathrm{CO}_{2}$ contents ( $\left.\geq 220-280 \mathrm{ppm}\right)$ and pre-eruptive LERZ melt depths $(\geq 2.2 \mathrm{~km})$ from volatile measurements in matrix glasses and MI. Melt inclusions from the basaltic pumice tightly constrain the pre-eruptive $\mathrm{H}_{2} \mathrm{O}$ contents of F8 melts at $\sim 0.3 \mathrm{wt} \%$, at least at their time of eruption in late May. The F8 magmas were sourced from depths of $1-5 \mathrm{~km}$ within the Halema' uma' $u$ and South Caldera reservoirs, or along the ERZ, with the majority of F8 magmas likely sourced from depths $\leq 3 \mathrm{~km}$. These petrologic observations are in good agreement with seismicity and deformation-based models of summit magma extraction and dike intrusion depths (Anderson et al. 2019; Neal et al. 2019; MontgomeryBrown et al. 2020), and do not require deeper origins for magmas feeding the LERZ eruption.

The relatively shallow LERZ F8 magma source depths support the hypothesis of Epp et al. (1983) that hydraulic head influences the style and volumes of Killauea eruptions at low elevations in the LERZ and further offshore. The 2018 LERZ eruption occurred at an elevation of $\sim 200 \mathrm{~m}$ above sea level, and the dike feeding the LERZ eruption was $\sim 2-3 \mathrm{~km}$ beneath the surface in the LERZ (1.8-2.8 km below sea level [bsl]); the LERZ dike was thus at an elevation mostly below the Halema' uma'u reservoir (0-2 km bsl) but comparable to 



Fig. 12 Conceptual model of processes occurring at Kīlauea's summit and East Rift Zone (ERZ) from March to August 2018. (a) Volatile-rich melts ascend into Kîlauea's South Caldera and Halema'uma'u (HMM) reservoirs, exsolving $\mathrm{CO}_{2}$-rich gases. Convecting magma at the summit lava lake degasses $\mathrm{SO}_{2}$ and $\mathrm{H}_{2} \mathrm{O}$ and then sinks to lower levels in the Halema'uma' $u$ ( \pm South Caldera) reservoir, as well as entering the ERZ where it feeds the Pu' $\mathrm{u}^{\prime} \bar{o}^{`} \bar{o}$ eruption. In March to April, a constriction within the shallow $\mathrm{Pu}^{\prime} \mathrm{u}^{`} \bar{o}^{`} \overline{\mathrm{o}}$ system decreases lava and gas effusion rates, however continued magma inflow into the summit and ERZ causes pressurization at both $\mathrm{Pu}^{6} \mathrm{u}^{\prime} \overline{\mathrm{o}}^{\natural} \overline{\mathrm{o}}$ and at the summit (blue arrows). (b) May to June:

the upper portions of the South Caldera reservoir (2-4 km bsl). Magma in the Halema'uma'u reservoir could therefore provide substantial hydraulic head to drive the LERZ eruption, and eruptions further offshore would amplify this effect. Low-elevation and offshore eruptions sourced from shallow Kīlauea reservoirs may thus drain large volumes of the summit reservoirs (Epp et al. 1983). Indeed, large lavadraining events in the LERZ have led to summit collapses during a dike intrusion (and possible offshore eruption) in 1924, during the 1960 Kapoho eruption (Delaney and
A dike propagates from beneath $\mathrm{Pu}^{6} \mathrm{u}^{\prime} \bar{o}^{`} \overline{\mathrm{o}}$ to feed the LERZ eruption. Magma sourced from the summit reservoirs hybridize with various parcels of previously degassed summit magmas, as well as ERZ and LERZ magmas (magmas are colored and textured to respectively illustrate differences in temperatures and volatile contents). (c) July to August: The summit collapse broadens and melts sourcing F8 are increasingly hotter, although not more sulfur-rich. Magma is sourced from the deep Halema'uma'u and South Caldera reservoirs, and includes antecrystic phenocrysts from variably degassed and primitive magmas. Note the change of horizontal scale between (a) and (b, c)

McTigue 1994), and witnessed dramatically during the 2018 LERZ eruption (Anderson et al. 2019; Neal et al. 2019).

\section{Evidence for previous degassing of fissure 8 magmas}

The ranges of sulfur contents and $\delta^{34} \mathrm{~S}$ values measured in MI from F8 tephras and lavas provide further insights into subsurface magma diversity at Kỉlauea. However, to understand our observations in LERZF8 samples, we must consider processes occurring within the Kīlauea plumbing system in past decades to centuries. 
We propose that the decade of degassing from the Halema'uma'u lava lake may have had a significant effect on the volatile contents LERZ magmas. Rowe et al. (2015) observe that MI in olivine that erupted in 2008 from the Halema'uma'u lava lake generally contained $900-1300$ ppm $\mathrm{S}$ (and rarely up to 1400-1600 ppm S), whereas matrix glasses in lava lake spatter contained $\sim 200 \mathrm{ppm} \mathrm{S}$. These differences indicated that $\sim 80 \%$ of initial sulfur was degassed from the melt during ascent and circulation within the lava lake (Edmonds et al. 2013; Rowe et al. 2015). The degassed magma that circulated through the Halema 'uma'u lava lake from 2008-2018 is thought to have eventually erupted at $\mathrm{Pu}^{\text {' }} \mathrm{u}^{\text {'o }} \overline{\mathrm{o}}^{\text {' }}$. This association is based on the observed hydraulic connection between the lava lake and $\mathrm{Pu}^{\prime} \mathrm{u}^{`} \bar{o}^{`} \overline{\mathrm{o}}$ (Patrick et al. 2015, 2019b, 2021), the similar $\mathrm{K}_{2} \mathrm{O}$ and $\mathrm{TiO}_{2}$ compositions of magma erupting at both locations (Thornber et al. 2015; Gansecki et al. 2019; Lee et al. 2019), and the drastic decrease in $\mathrm{SO}_{2}$ emissions from $\mathrm{Pu}^{\text {' }} u^{\prime}{ }^{\prime}{ }^{\prime} \bar{o}$ in the years following the onset of degassing at Halema'uma' $u$ ( $2 \mathrm{kt} /$ day in 2003-2008 to $\leq 0.3 \mathrm{kt} /$ day in 2013-2018; [Elias and Sutton 2012; Sutton and Elias 2014; Elias et al. 2018a, 2020; Kern et al. 2020]). After briefly exceeding 10 $\mathrm{kt} / \mathrm{d}$ during the onset of the summit eruption, $\mathrm{SO}_{2}$ emissions from the Halema'uma' $u$ lava lake leveled off at $\sim 4.5$ $\mathrm{kt} / \mathrm{d}$ from 2009-2018 (Beirle et al. 2014; Elias et al. 2018b, 2020) (Fig. 12b); based on this decade-long average emission rate, the cumulative mass of $\mathrm{SO}_{2}$ degassed during convection within the lava lake from March 2008 to May 2018 ( 3710 days of activity) was $\sim 16.7$ Mt. Assuming that melt entering the lava lake contained $1100-1300 \mathrm{ppm}$ $\mathrm{S}$ and degassed $80 \%$ of total sulfur, and that the bubble-free magma contained $2 \%$ crystals (Thornber et al. 2015) and had a density of $2700 \mathrm{~kg} / \mathrm{m}^{3}$, the cumulative $\mathrm{SO}_{2}$ emissions require 3.0-3.6 $\mathrm{km}^{3}$ (DRE) of source magma convecting and degassing over the lifespan of the lava lake (time-averaged magma flux of $9.5-11.2 \mathrm{~m}^{3} / \mathrm{s}$ through the lava lake).

Over this same approximate timespan (July 2007 to May 2018), only $\sim 1.2 \mathrm{~km}^{3}$ of magma (DRE) was erupted from $\mathrm{Pu}^{6} \mathrm{u}^{\prime} \bar{o}^{`} \overline{\mathrm{o}}$ (compiled from Orr et al. 2015 and Neal et al. 2019). Comparing these time periods at Halema'uma'u and $\mathrm{Pu}^{`} \mathrm{u}^{\prime} \overline{\mathrm{o}}^{`} \overline{\mathrm{o}}$ is somewhat imperfect due to a delay between magma circulating in the lava lake and erupting at $\mathrm{Pu}^{6} \mathrm{u}^{6} \overline{\mathrm{o}}^{\natural} \overline{\mathrm{o}}$ (Thornber et al. 2015; Patrick et al. 2019b). Nevertheless, the fundamental conclusion is that far more magma underwent extensive degassing in the Halema'uma'u lava lake than was erupted at $\mathrm{Pu}^{\prime} \mathrm{u}^{`} \mathrm{o}^{`}{ }^{`} \mathrm{o}$. Assuming that magma erupting at $\mathrm{Pu}^{\prime} \mathrm{u}^{\varsigma} \overline{\mathrm{o}}^{`} \mathrm{o}$ was sourced entirely from lava lake-degassed magma, $>2 \mathrm{~km}^{3}$ of degassed magma was not erupted. If some portion of magma erupted from $\mathrm{Pu}^{\prime} u^{\prime}{ }^{'} \bar{o}^{`} \mathrm{o}$ had not cycled through the lava lake, then the amount of lava lakedegassed but non-erupted magma correspondingly increases. The importance of the recycling of degassed magma from Halema'uma'u lava lake has been discussed (Elias and Sutton
2012; Edmonds et al. 2013; Patrick et al. 2019a), however the magnitude of this recycling has perhaps not been fully appreciated. This large volume of degassed, non-erupted melt presumably remained (and perhaps still remains post-2018) within the summit or upper/middle ERZ magma reservoirs in varying states of hybridization with non-degassed magmas (Fig. 12).

$\mathrm{H}_{2} \mathrm{O}$ and sulfur largely degas in tandem from Kīlauea melts (Gerlach 1986; Dixon et al. 1991; Wallace and Anderson 1998; Edmonds et al. 2013), so degassed Halema'uma'u lava lake melts would be depleted in both sulfur and $\mathrm{H}_{2} \mathrm{O}$. Our estimated pre-eruptive $\mathrm{H}_{2} \mathrm{O}$ and sulfur contents of LERZ F8 melts $\left(\sim 0.3 \mathrm{wt} \% \mathrm{H}_{2} \mathrm{O}, \sim 1110 \mathrm{ppm}\right.$ $\mathrm{S}$; Wieser et al. 2021; this study) are relatively low compared to volatile concentrations measured in many other Kîlauea summit and LERZ eruptions (e.g., 0.3-0.4 wt\% $\mathrm{H}_{2} \mathrm{O}, 1000$ to $\geq 1400$ ppm S in 2008-2010 Halema'uma'u lava lake tephra; 0.4 to $\geq 0.7 \mathrm{wt} \% \mathrm{H}_{2} \mathrm{O}, 1000-1500 \mathrm{ppm} \mathrm{S}$ in 1959 Kîlauea Iki and 1960 Kapoho samples [Anderson and Brown 1993; Wallace and Anderson 1998; Edmonds et al. 2013; Sides et al. 2014a, b; Rowe et al. 2015; Tuohy et al. 2016; Helz et al. 2017; Tucker et al. 2019]). We hypothesize that the lower $\mathrm{H}_{2} \mathrm{O}$ and sulfur contents of LERZ F8 melts are a consequence of the magma containing some degree of previously degassed melt from the Halema' uma'u lava lake. This may explain why the LERZ F8 melts have sulfur concentrations below SCSS ${ }^{\mathrm{T}}$, whereas many other eruptions during the twentieth century were sulfide-saturated (1959, 1960, 1969-1974, 1977 eruptions [Desborough et al. 1968; Moore et al. 1980; Helz and Wright 1992; Clague et al. 1995; Helz et al. 2017; Wieser et al. 2020]). Wallace and Anderson (1998) observe that undegassed Kīlauea melts across a range of compositions have an average $\mathrm{H}_{2} \mathrm{O} / \mathrm{K}_{2} \mathrm{O}$ ratio of 1.3 , whereas rapidly quenched MI from early phase 3 basaltic pumice have $\mathrm{H}_{2} \mathrm{O}$ / $\mathrm{K}_{2} \mathrm{O}$ ratios of $0.6-1.0$. These low $\mathrm{H}_{2} \mathrm{O} / \mathrm{K}_{2} \mathrm{O}$ ranges from F8 glasses are similar to MI from 1959 Kīlauea Iki and $\mathrm{Pu}^{\text {' }} \mathrm{u}^{\text {' }} \overline{ }^{\text {' }} \overline{\mathrm{o}}$, and to submarine glasses from the Puna Ridge that Wallace and Anderson (1998) proposed had experienced $\mathrm{H}_{2} \mathrm{O}$-loss during lava drain-back and recycling. Unfortunately, all MI in samples erupted between June and August likely experienced diffusive $\mathrm{H}_{2} \mathrm{O}$-loss (though not diffusive sulfur-loss) during lava flow transport. Thus, we cannot definitively constrain whether pre-eruptive melt $\mathrm{H}_{2} \mathrm{O}$ varied during the course of the eruption.

Despite the extremely high gas emissions from the LERZ fissures, the available measurements of MI and matrix glasses from F8 suggest that LERZ phase 3 melts were not particularly volatile-rich compared to past Kīlauea eruptions. The relatively low F8 lava fountain heights are consistent with this hypothesis. The highest lava fountains at F8 during early phase 3 had maximum heights of $\sim 80 \mathrm{~m}$ (Neal et al. 2019), whereas the 1959 Kīlauea Iki fountain heights 
reached $600 \mathrm{~m}$, the 1960 Kapoho fountain heights reached $450 \mathrm{~m}$, the 1969 Mauna Ulu fountains reached 300-540 m (Swanson et al. 1979), and the $1983 \mathrm{Pu}^{\prime} \mathrm{u}^{`} \bar{o}^{`} \bar{o}$ fountain heights reached 200-400 m (Richter et al. 1970; Wolfe et al. 1987). The total volatile content of the melt strongly controls lava fountain heights (Head and Wilson 1987), although conduit geometry and lava ponding within erupting cinder cones also modulate fountaining (Wilson et al. 1995). Of these historical eruptions, only the 2018 LERZ eruption had been immediately preceded by a decade of sustained lava lake degassing and convective magma recycling.

\section{The recycling of degassed magmas throughout Kïlauea's history}

Prolonged summit lava lake activity has been common in Kîlauea's recent history, with persistent lava lakes present throughout much of the nineteenth and early twentieth centuries (1823-1894 and 1906-1924) (Ellis 1825; Wright and Klein 2014; Patrick et al. 2019a, 2021). Lava lakes presumably also occurred during pre-historic periods of effusive activity (Holcomb 1987; Swanson et al. 2014). Any period of sustained bottom-fed lava lake activity requires melt convection to shallow depths, with concomitant $\mathrm{H}_{2} \mathrm{O}$ and sulfur degassing (Edmonds et al. 2013). In addition, the drain-back of erupted lava is also relatively common during summit and rift zone eruptions at Kīlauea. Lava drain-back during the 1959 Kīlauea Iki eruption was well documented visually and petrologically (Richter et al. 1970; Wallace and Anderson 1998). Lava drain-back also occurred during the early phases of the $\mathrm{Pu}^{\prime} \mathrm{u}^{\prime}{ }^{\prime}{ }^{`}$ o eruption in 1983 (Wolfe et al. 1987) and during the 2011 Kamoamoa eruption, where surface lava flows poured into a nearby ground crack (Orr et al. 2015). Most recently, lava drain-back was documented during the early weeks of Kîlauea's renewed summit eruption (December 2020), where a rising lava lake inundated the erupting northern fissure and caused a period of lava drainage (USGS-HVO 2020b). Both lava lake convection and lava drain-back events recycle volatile-depleted melts back into the Kîlauea magma storage systems (Wallace and Anderson 1998; Edmonds et al. 2013). We therefore support the hypothesis originally postulated by Dixon et al. (1991), Clague et al. (1995), and Wallace and Anderson (1998) that the recycling of degassed magma is a common and important process at Kīlauea.

The vertical mixing of degassed magma back into the shallow Kîlauea magmatic system is an inevitable consequence of increasing melt density with volatile loss and cooling. However, it is unknown to what degree recycled partially degassed magma is re-homogenized within larger magma storage regions, or to what depths degassed magma might sink. If mixing is incomplete, multiple heterogeneous magma batches with variable volatile contents could exist within Kīlauea's magma storage network (Fig. 12). Sulfurand $\mathrm{H}_{2} \mathrm{O}$-poor Puna Ridge submarine lava flows that erupted in water depths $>1 \mathrm{~km}$, where hydrostatic pressure would have prevented sulfur and $\mathrm{H}_{2} \mathrm{O}$ degassing, provide strong evidence for the recycling of shallowly degassed magma batches through the Kīlauea system and ERZ (Dixon et al. 1991). In those cases, the signature of shallow degassing was not completely re-homogenized by mixing, despite the Puna Ridge magmas traveling through the full Kîlauea ERZ magma transport system.

Many MI within high-Fo olivine from LERZ F8 magmas are also sulfur-poor (Fig. 7). $\mathrm{H}_{2} \mathrm{O}-\mathrm{CO}_{2}$ derived entrapment depths of some of these sulfur-poor, primitive $\mathrm{MI}$ are as shallow as $<1-2 \mathrm{~km}$ (Fig. 9c). These MI also have low $\delta^{34} \mathrm{~S}$ values (Fig. 9d), consistent with the melt becoming isotopically light during $\mathrm{SO}_{2}$ degassing at very low pressures $(<200 \mathrm{~m})$. These lines of evidence indicate that at times in the past, highly primitive Kîlauea magmas $\left(\geq 1200^{\circ} \mathrm{C}\right)$ reached very shallow depths and underwent substantial degassing. However, convective degassing and recycling during 2008-2018 Halema'uma'u lava lake activity involved more evolved magma $\left(\mathrm{Fo}_{80-83}\right.$, rarely to $\left.\mathrm{Fo}_{86}\right)$ (Edmonds et al. 2013; Rowe et al. 2015; Thornber et al. 2015) and is therefore not an appropriate scenario to explain our observations of degassed MI hosted within high-Fo olivine. A more analogous situation would be the 1959 Kîlauea Iki eruption, which involved the eruption and partial drain-back of variably mixed magma that had calculated melt temperatures up to $1200{ }^{\circ} \mathrm{C}$ and contained unrimmed $\mathrm{Fo}_{84-89}$ olivine (Anderson and Brown 1993; Wallace and Anderson 1998; Sides et al. 2014b; Tuohy et al. 2016; Helz et al. 2017). Other summit and ERZ eruptions containing abundant high-Fo olivine have occurred throughout Kîlauea's history (e.g., Mauna Ulu 1969-1974 and the Keanakāko 'i tephra 1500-1820 [(Vinet and Higgins 2011; Lynn et al. 2017]), and perhaps a number of these eruptions similarly involved lava drain-back or convective recycling of shallowly degassed primitive magmas to form the degassed MI we observe in high-Fo olivine from F8.

A small subset of sulfur-poor and $\delta^{34} \mathrm{~S}$-light $\mathrm{MI}$ in highFo olivine have fairly high $\mathrm{CO}_{2}$ concentrations, which indicate entrapment depths of 3-5 km (see "deep recycling" labels in Fig. 9c, d). These measurements indicate that sulfur-degassed melts existed at South Caldera reservoir depths prior to MI entrapment. This is surprising because Kīlauea melts undergoing sulfur $\left(\right.$ and $\mathrm{H}_{2} \mathrm{O}$ ) degassing would have almost completely degassed $\mathrm{CO}_{2}$ (Gerlach 1986). To produce sulfur-poor melts with high $\mathrm{CO}_{2}$ concentrations, it seems necessary that sulfur- and $\mathrm{CO}_{2}$-degassed melts sank to South Caldera reservoir depths and were then mixed with undegassed melts with $\mathrm{CO}_{2}$-rich gas bubbles (Dixon et al. 1991) and/or were fluxed by $\mathrm{CO}_{2}$-rich but relatively sulfur(and $\mathrm{H}_{2} \mathrm{O}-$ ) poor fluids ascending from greater depths (e.g., reservoir gas; Gerlach 1986). Melt inclusions forming in 
these settings would thereby trap melts that are sulfur- (and $\mathrm{H}_{2} \mathrm{O}$-) poor but $\mathrm{CO}_{2}$-rich and vapor-saturated at their trapping depths. During subsequent magma mixing, olivinehosted MI would quickly re-equilibrate with external melt $\mathrm{H}_{2} \mathrm{O}$ concentrations (e.g., Hauri 2002; Portnyagin et al. 2008; Bucholz et al. 2013; Barth et al. 2019), but the originally entrapped sulfur and $\mathrm{CO}_{2}$ concentrations in MI would be preserved. Pervasive $\mathrm{CO}_{2}$ degassing occurs throughout the Kîlauea summit caldera during both eruptive and quiescent periods indicating a steady influx of deep $\mathrm{CO}_{2}$-saturated magma (Gerlach et al. 2002). The fluxing of $\mathrm{CO}_{2}$-rich vapors through portions of Kīlauea's summit reservoirs should thus be expected.

\section{The potential role of magma recycling in triggering the LERZ eruption}

The cascading sequence of events that led to the LERZ eruption has been well described by Patrick et al. (2020b), where the clogging of the $\mathrm{Pu}^{\prime} \mathrm{u}^{`} \bar{o}^{`} \bar{o}$ vent in early 2018 is identified as a critical precursory process that pressurized the entire shallow Kĩlauea magma system. We build upon this hypothesis and propose that the $\mathrm{Pu}^{\prime} \mathrm{u}^{`}{ }^{`} \mathrm{o}^{`} \mathrm{o}$ blockage was the result of its feeder magma becoming progressively volatile-depleted and increasingly viscous since the onset of Halema'uma'u lava lake degassing.

Magma circulation and degassing in the Halema 'uma' $u$ lava lake would have caused substantial $\mathrm{H}_{2} \mathrm{O}$ degassing and slight cooling of the melt (Edmonds et al. 2013), both of which would increase melt viscosity (Lesher and Spera 2015). During the 10 years that the Halema'uma'u lava lake and $\mathrm{Pu}^{\prime} \mathrm{u}^{\prime} \overline{\mathrm{o}}^{`} \overline{\mathrm{o}}$ were hydraulically connected, the magmas feeding $\mathrm{Pu}^{\prime} \mathrm{u}^{\prime} \bar{o}^{\prime} \overline{\mathrm{o}}$ contained increasing proportions of lava lake-degassed magma, as indicated by the progressive decrease in $\mathrm{SO}_{2}$ emission rates from $\mathrm{Pu}^{\text {' }} \mathrm{u}^{\text {' }} \mathrm{o}$ 'o beginning in 2009 (Elias and Sutton 2012; Sutton and Elias 2014) (Fig. 13a). In contrast, degassing from Halema'uma'u remained relatively steady from 2009-2018, indicating a fairly constant magma supply into the shallow summit reservoir and lava lake (Elias and Sutton 2012; Beirle et al. 2014; Elias et al. 2018a, 2020) (Fig. 13b). Although $\mathrm{H}_{2} \mathrm{O}$ has not been measured in recent glasses from $\mathrm{Pu}^{\prime} \mathrm{u}^{6} \bar{o}^{`} \overline{\mathrm{o}}$ (due to the lack of rapidly quenched tephra), the similar shallow degassing behavior of sulfur and $\mathrm{H}_{2} \mathrm{O}$ (Fig. 8) indicates that decreasing $\mathrm{H}_{2} \mathrm{O}$ contents of $\mathrm{Pu}^{\text {' }} \mathrm{u}^{\prime} \bar{o}^{\prime} \bar{o}$ melts would have accompanied the observed decrease in $\mathrm{SO}_{2}$ emissions since 2009. As magmas feeding $\mathrm{Pu}^{\prime} \mathrm{u}^{\prime} \overline{\mathrm{o}}^{`} \overline{\mathrm{o}}$ became increasingly composed of lava lake-degassed material, the viscosity of the $\mathrm{H}_{2} \mathrm{O}$-depleted magma would have increased, making the magma less able to easily ascend and erupt at $\mathrm{Pu}^{\prime} \mathrm{u}^{\prime} \overline{\mathrm{o}}^{`} \overline{\mathrm{o}}$. For example, between 2008 and 2018, decreases in $\mathrm{Pu}^{\prime} \mathrm{u}^{\prime} \overline{\mathrm{o}}^{`} \mathrm{o}$ melt temperatures from $1150{ }^{\circ} \mathrm{C}$ to $1140{ }^{\circ} \mathrm{C}$ (Thornber et al. 2015; Lee et al. 2019) and in $\mathrm{H}_{2} \mathrm{O}$ contents from 0.4 to $0.1 \mathrm{wt} \%$ (estimated from measurements of Wallace and Anderson [1998]) would respectively increase melt viscosities by $\sim 20 \%$ and $~ 35 \%$ (Lesher and Spera 2015) (note: melt density would increase by only $\sim 1 \%$ with these temperature and composition variations). Increased crystallinity due to melt cooling and dehydration would further increase magma viscosities (Lesher and Spera 2015). Perhaps unrelated, but conspicuously timed, more $\mathrm{K}_{2} \mathrm{O}$ - and $\mathrm{TiO}_{2}$-rich magma compositions began erupting from both Halema'uma'u and

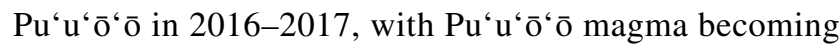
particularly $\mathrm{K}_{2} \mathrm{O}$-enriched in 2017 (Gansecki et al. 2019; Lee et al. 2019) (Fig. 13c, d).

We propose that some combination of a changing magma source and the long-term decrease in melt temperatures and volatile contents due to Halema'uma'u lava-lake convection and recycling caused the viscosity of $\mathrm{Pu}^{\prime} \mathrm{u}^{\prime} \overline{\mathrm{o}}^{\prime} \mathrm{o}$ magma to increase to the point that the conduit started clogging (Orr et al. 2015; Patrick et al. 2019b). This conduit constriction resulted in the decreased lava effusion rates and gas emissions observed at $\mathrm{Pu}^{\prime} \mathrm{u}^{\prime} \bar{o}^{`} \mathrm{o}$ in early 2018 (Kern et al. 2020), which led to the system-wide pressurization of Kīlauea in March and April (Patrick et al. 2019a, 2020b; Neal et al. 2019). This pressurization built to the point that a dike rupture occurred beneath $\mathrm{Pu}^{\text {' }} \mathrm{u}^{\text {' }} \overline{\mathrm{o}}^{`} \overline{\mathrm{o}}$, thus initiating the dramatic LERZ eruption sequence (Patrick et al. 2020b) (Fig. 12). We therefore consider the 2018 LERZ eruption to be dominantly caused by a top-down process related to decreasing volatile contents and increasing viscosities of the magmas feeding $\mathrm{Pu}^{6} \mathrm{u}^{\prime} \bar{o}^{`} \overline{\mathrm{o}}$. In this scenario, the LERZ eruption "trigger" was a decade in the making, since degassing began at the Halema' uma'u lava lake in 2008. Seismic and geochemical evidence suggests that deep magma recharge was occurring in the months to years preceding the LERZ eruption (Flinders et al. 2020; Mourey et al. 2019), which may have additionally contributed to the system's overall pressurization and cascading series of events (Patrick et al. 2020b). Future efforts to mechanically model the consequences of changing viscosity on lava effusion and pressurization at $\mathrm{Pu}^{6} \mathrm{u}^{6}{ }^{\complement}{ }^{6} \bar{o}$ would provide insights into the feasibility of the top-down model for the LERZ eruption trigger and whether deeper pressurization was additionally required to initiate down-rift diking.

\section{Conclusions and applications to post-2018 activity}

We combined major element, volatile, and $\delta^{34} S$ measurements of matrix glasses and MI from Kīlauea's 2018 LERZ eruption to provide insights into a variety of subsurface and lava emplacement processes. The diversity of lavas, phenocrysts, and glasses produced during the LERZ eruption 

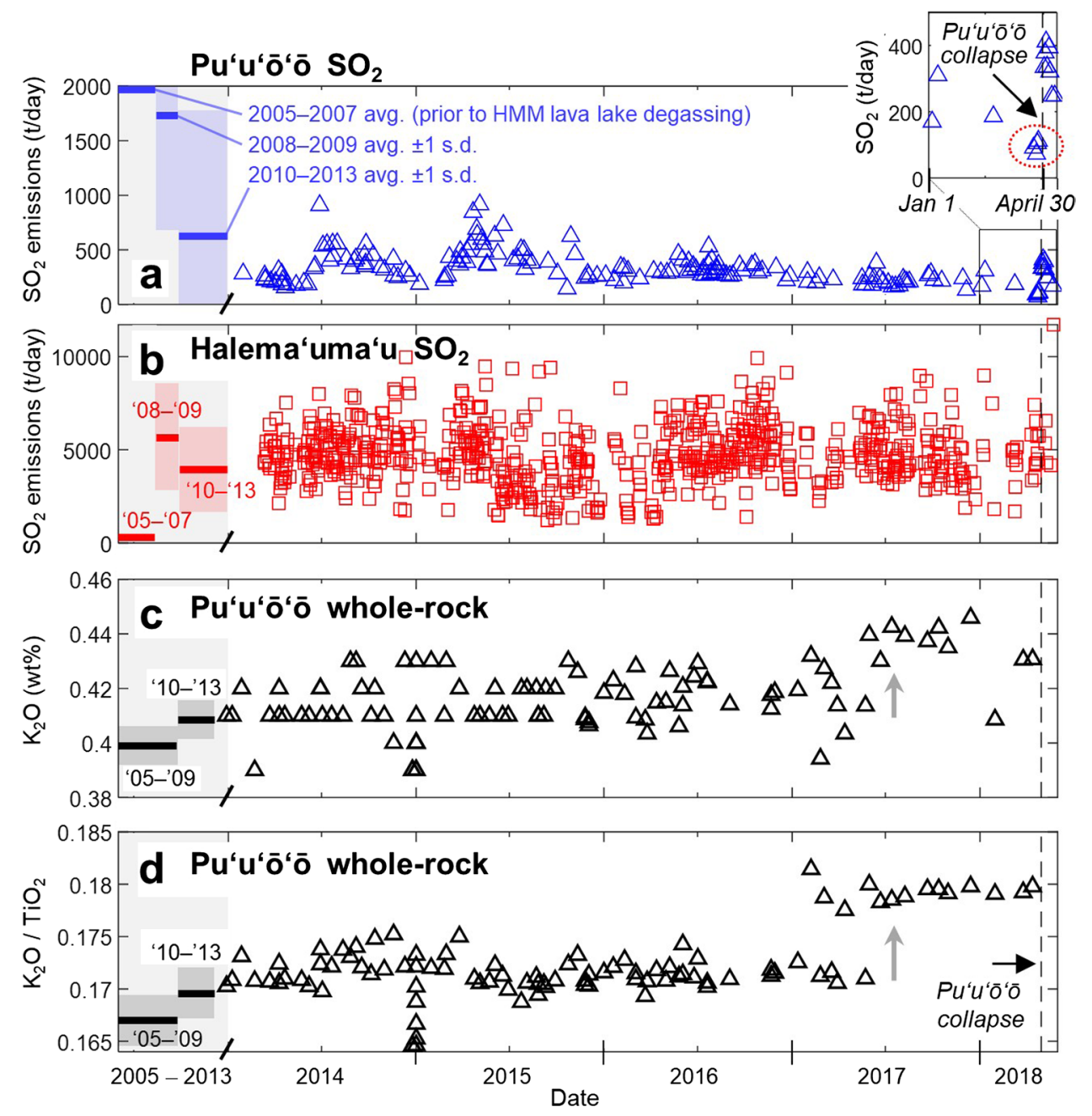

Fig. 13 Time series from January 2013 to May 2018 of daily averaged $\mathrm{SO}_{2}$ emissions from $\mathrm{Pu}^{\prime} \mathrm{u}^{\prime} \bar{o}^{`} \overline{\mathrm{o}}$ and the Halema'uma'u lava lake (HMM), and of $\mathrm{Pu}^{\prime} \mathrm{u}^{\prime} \bar{o}^{`} \overline{\mathrm{o}}$ whole-rock $\mathrm{K}_{2} \mathrm{O}$ and $\mathrm{K}_{2} \mathrm{O} / \mathrm{TiO}_{2}$ concentrations. (a) $\mathrm{SO}_{2}$ emission rates at $\mathrm{Pu}^{\prime} u^{\prime} \bar{o}^{`} \mathrm{o}$ progressively declined after the onset of degassing from the summit lava lake in 2008; horizontal lines and shaded regions show average $\mathrm{SO}_{2}$ emission rates \pm 1 s.d. from prior years. In the two months prior to the collapse of $\mathrm{Pu}^{4} \mathrm{u}^{\varsigma}{ }^{\varsigma}{ }^{\natural} \overline{\mathrm{o}}$ and the onset of the LERZ eruption (vertical dashed line), $\mathrm{SO}_{2}$ emission rates from $\mathrm{Pu}^{`} \mathrm{u}^{`} \overline{\mathrm{o}}^{`} \mathrm{o}$ were among the lowest ever measured (see

make this a particularly rich dataset for improving our understanding of the 2018 eruption and the overall Killauea magmatic system.

As a consequence of pre-eruptive melt diversity, postentrapment MI modification, and degassing during ascent and emplacement, sulfur contents in LERZ glasses are highly variable. Long-stored, lower temperature evolved basalts erupted in phase 1 of the LERZ activity are significantly enriched in sulfur and chlorine (and likely $\mathrm{H}_{2} \mathrm{O}$ ) compared to the dominant phase 3 mafic magmas from $\mathrm{F} 8$. Fractional crystallization likely caused volatile enrichment (Fig. S16) and also increased $\mathrm{FeO}^{\mathrm{T}}$ (and thereby $\mathrm{SCSS}^{\mathrm{T}}$ ) circled measurements in inset at top). (b) $\mathrm{SO}_{2}$ emission rates from the Halema'uma'u lava lake remained relatively constant from 2008 until after the summit collapse began during the 2018 LERZ eruption. (c, d) $\mathrm{K}_{2} \mathrm{O}$ and $\mathrm{K}_{2} \mathrm{O} / \mathrm{TiO}_{2}$ of $\mathrm{Pu}^{\text {' }} \mathrm{u}^{\text {'o }}{ }^{`} \overline{\mathrm{o}}$ whole-rock chemistry are relatively independent of changing gas emissions, but changes in 2017 (gray arrows) suggests a variation in the lava source or mixing pro-

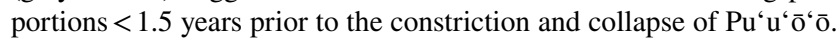
Data are from Elias and Sutton (2012), Thornber et al. (2015), Elias et al. (2018b, 2020), Gansecki et al. (2019), and Kern et al. (2020)

in these early erupted melts. In phase 3 magmas from $\mathrm{F} 8$, primitive olivine $\left(\mathrm{Fo}_{86-89}\right)$ from $1220-1310{ }^{\circ} \mathrm{C}$ magmas were incorporated into bulk carrier melts that were $70-170{ }^{\circ} \mathrm{C}$ cooler (containing equilibrium $\mathrm{Fo}_{78-81}$ olivine), which caused extensive PEC and Fe-loss in MI within the highFo olivine. These post-entrapment modifications resulted in widespread vapor bubble and sulfide formation within MI, which respectively sequestered the majority of $\mathrm{CO}_{2}$ and $10-50 \%$ of total sulfur in affected MI.

An updated degassing model for Kîlauea, following the approach of Gerlach (1986), indicates that large scale sulfur and $\mathrm{H}_{2} \mathrm{O}$ degassing only occurs at very shallow depths below the 
surface $(\leq 200 \mathrm{~m})$, whereas $\mathrm{CO}_{2}$ degassing occurs throughout the crust. Sulfur concentrations in MI do not strongly correlate with melt or mineral host compositions or with entrapment depths, indicating complex degassing and recycling histories prior to MI entrapment. We estimate that melts feeding the bulk of the LERZ lava effusion from F8 had pre-eruptive volatile concentrations of $\sim 1110 \mathrm{ppm} \mathrm{S}, 0.3 \mathrm{wt} \% \mathrm{H}_{2} \mathrm{O}$, and at least 225-280 ppm $\mathrm{CO}_{2}$. These estimates are roughly consistent with degassing models and measured gas ratios at F8 (Kelly et al. 2021). A petrologically derived time series of $\mathrm{SO}_{2}$ emissions from lava effusion rates also largely agrees with observed $\mathrm{SO}_{2}$ emissions (Kern et al. 2020; Dietterich et al. 2021). Measurements of sulfur in $\mathrm{F} 8$ glasses and of $\mathrm{SO}_{2}$ emission rates of LERZ "fissure gas" and "channel gas" indicate that $~ 55-90 \%$ of the magmatic sulfur was degassed during ascent and eruption, whereas $10-45 \%$ of sulfur remained in the lava and degassed during surface flow. We conclude that record-setting $\mathrm{SO}_{2}$ emission rates during this eruption are a function of the extremely high rates of lava effusion rather than the LERZ F8 melts being anomalously sulfur-rich.

$\mathrm{SO}_{2}$ degassing causes $\delta^{34} \mathrm{~S}$ to decrease in LERZ melts from initial values of +1.0 to $+1.5 \%$ o down to $-2.5 \%$ in sulfur-degassed matrix glasses. This $\delta^{34} \mathrm{~S}$ range is largely consistent with prior isotopic measurements of degassed subaerial and non-degassed submarine lavas (Sakai et al. 1982 ) and indicates that $\delta^{34} S$ values can be used to identify sulfur-degassed Kīlauea melts.

Melt inclusions in both low- and high-Fo olivine have entrapment depths of $1-5 \mathrm{~km}$, showing that the magmas feeding the LERZ F8 fissure were stored at depths consistent with the geophysically inferred Halema'uma' $u$ and South Caldera reservoirs (Poland et al. 2014; Anderson et al. 2019; Wieser et al. 2021); our measurements do not require the input of more deeply derived magmas during the LERZ eruption. Melt inclusion volatile concentrations, $\delta^{34} \mathrm{~S}$ degassing signatures, and vapor-bubble restored entrapment pressure estimates indicate that recycling of shallowly degassed magma is common at Kîlauea, likely due to lava lake activity and lava drain-back events. In particular, many MI in high-Fo LERZ olivine are sulfur-poor, indicating that at some point in Kîlauea's past, high temperature melts had ascended to near-surface conditions followed by degassing, melt densification, and sinking.

The 2018 LERZ eruption was similar to the 1960 LERZ eruption of Kapoho (Tuohy et al. 2016) in that both eruptions contained a diverse range of primitive to evolved melts and phenocrysts. However, the 2018 LERZ eruption was dominantly fed by shallow magmas, whereas the Kapoho eruption involved a substantial portion of more deeply sourced magma. Despite the prodigious gas emissions during the 2018 LERZ activity, erupted melts at F8 were somewhat volatile-poor and had lower fountain heights compared to Kapoho and other Kīlauea eruptions, presumably due to the previous decade of melt degassing and recycling within the Halema'uma'u lava lake. We suspect that the decade of lava lake degassing preceding the LERZ eruption contributed to the constriction and pressurization of $\mathrm{Pu}^{6} \mathrm{u}^{6} \overline{\mathrm{o}}^{`} \overline{\mathrm{o}}$, which ultimately ruptured and initiated the LERZ eruption.

Following the LERZ eruption, gradual inflation began at Kîlauea's summit, indicating continued magma recharge into the remnant shallow Halema'uma'u reservoir (Poland et al. 2019). Groundwater ingress into Kīlauea's vastly deepened summit caldera led to the growth of a water lake in 2019-2020 (Hsieh and Ingebritsen 2019; Ingebritsen et al. 2021). Our updated degassing model indicates that the exsolution of reservoir-equilibrated volatiles $\left(\mathrm{CO}_{2}\right.$-rich, with $15 \mathrm{~mol} \%$ sulfur$)$ during magma ascent from South Caldera reservoir depths to the depth of the refilling shallow Halema' uma'u reservoir can result in 5-10\% of initial sulfur degassing from the melt. We suspect that this type of degassing from the new magma ascending into Halema'uma' $u$ reservoir depths was the source of observed summit solfataras and high levels of sulfate in the summit lake (Nadeau et al. 2020; S. Peek, U.S. Geological Survey, written communication). However, given the high solubility of sulfur in Kîlauea melts until depths of $<200 \mathrm{~m}$ beneath the surface, and the large capacity of groundwater to scrub $\mathrm{SO}_{2}$ (Symonds et al. 2001), precursory $\mathrm{SO}_{2}$ emissions from future magma ascent to the near-surface would be challenging to observe. Indeed, the return of lava to Killauea's summit in December 2020, in the form of a fissure eruption within the deepened Halema' uma' $u$ crater, occurred with no apparent precursory increase in $\mathrm{SO}_{2}$ emissions (P. Nadeau, U.S. Geological Survey, written communication). This renewed summit eruption (ongoing as of April 2021) began with modest lava fountain heights ( $\leq 50 \mathrm{~m}$, USGS-HVO 2020a), suggesting that this eruption may also be sourced from partially degassed melts that are related to magma recycling during the 2008-2018 Halema'uma'u lava lake activity.

Supplementary Information The online version contains supplementary material available at https://doi.org/10.1007/s00445-021-01459-y.

Acknowledgements The authors would like to thank Matthew Loewen, Nicole Métrich, and Matt Patrick for constructive input that significantly improved this manuscript. The authors also thank the U.S. Geological Survey (USGS) Volcano Science Center, Hawaiian Volcano Observatory (HVO), University of Hawai'i-Hilo, partner agencies, and the residents of Hawai' $i$ for support, field access, data sharing, and for their great care in documenting and responding to the 2018 LERZ eruption crisis. AHL thanks Tina Neal and the HVO volunteer program for support, Mike Zoeller for map assistance, and Carolyn Parcheta for collecting and sharing samples. Geochemical analyses were conducted with the help of John Donovan and Julie Chouinard (EPMA), and Brian Monteleone and Glenn Gaetani (SIMS and MI rehomogenization). AHL thanks Michelle Muth and Madison Myers for discussions on methodology and melt inclusion interpretation. AHL acknowledges funding support from Department of Earth Sciences at the University of Oregon, the Mineralogical Society of America, the Geological Society of America, the Mazamas student research grant program, the National Science Foundation (NSF) Graduate Research Fellowship Program, and the NSF Graduate Research Internship Program (GRIP). Coordination of GRIP at the USGS is through the Youth and Education in Science programs within the Office of Science Quality and Integrity. 
Author contribution AHL and PJW led the study conception and design. Petrologic sample preparation, data collection, and analysis were performed by AHL, TS, AJM, LRM, CG, and RLL, and were interpreted by AHL, PJW, TS, AJM, CG, and RLL. Gas emission measurements were performed and interpreted by PAN, TE, CK, AHL, PJK, LEC, and CAW.

Funding This study received support from the NSF Graduate Research Fellowship Program under grant DGE-1309047 and from an internship provided through the Graduate Research Internship Program (GRIP). Part of the melt inclusion analyses was supported by NSF grant EAR-1725321.

Data availability Data are presented in electronic supplemental tables.

Code availability Not applicable.

\section{Declarations}

Conflict of interest The authors declare no competing interests.

Disclaimer Any use of trade, firm, or product names is for descriptive purposes only and does not imply endorsement by the U.S. Government. Any findings and conclusions or recommendations expressed in this material are those of the author(s) and do not necessarily reflect the views of the National Science Foundation.

\section{References}

Anderson AT (1974) Chlorine, sulfur, and water in magmas and oceans. Geol Soc Am Bull 85:1485-1492. https://doi.org/10. 1130/0016-7606(1974)85\%3C1485:CSAWIM\%3E2.0.CO;2

Anderson AT, Brown GG (1993) $\mathrm{CO}_{2}$ contents and formation pressures of some Kilauean melt inclusions. Am Mineral 78:794-803

Anderson KR, Poland MP (2017) Abundant carbon in the mantle beneath Hawai'i. Nat Geosci 10:704-708. https://doi.org/10. 1038/ngeo3007

Anderson KR, Johanson IA, Patrick MR, Gu M, Segall P, Poland MP, Montgomery-Brown EK, Miklius A (2019) Magma reservoir failure and the onset of caldera collapse at Kîlauea Volcano in 2018. Science 366:6470. https://doi.org/10.1126/science. aaz1822

Baker DR, Balcone-Boissard H (2009) Halogen diffusion in magmatic systems: our current state of knowledge. Chem Geol 263:82-88. https://doi.org/10.1016/j.chemgeo.2008.10.010

Barth A, Newcombe M, Plank T, Gonnermann H, Hajimirza S, Soto GJ, Saballos A, Hauri E (2019) Magma decompression rate correlates with explosivity at basaltic volcanoes-constraints from water diffusion in olivine. J Volcanol Geotherm Res 387:106664. https://doi. org/10.1016/j.jvolgeores.2019.106664

Beattie P (1993) Olivine-melt and orthopyroxene-melt equilibria. Contrib Mineral Petrol 115:103-111. https://doi.org/10.1007/BF00712982

Beaudry P, Longpré M-A, Economos R, Wing BA, Bui TH, Stix J (2018) Degassing-induced fractionation of multiple sulphur isotopes unveils post-Archaean recycled oceanic crust signal in hotspot lava. Nat Commun 9:1-12. https://doi.org/10.1038/ s41467-018-07527-w

Behrens H, Stelling J (2011) Diffusion and redox reactions of sulfur in silicate melts. Rev Mineral Geochem 73:79-111. https://doi. org/10.2138/rmg.2011.73.4
Beirle S, Hörmann C, Penning de Vries M, Dörner S, Kern C, Wagner $\mathrm{T}$ (2014) Estimating the volcanic emission rate and atmospheric lifetime of $\mathrm{SO}_{2}$ from space: a case study for Kîlauea volcano, Hawai'i. Atmospheric Chem Phys 14:8309-8322. https://doi.org/ 10.5194/acp-14-8309-2014

Bucholz CE, Gaetani GA, Behn MD, Shimizu N (2013) Post-entrapment modification of volatiles and oxygen fugacity in olivinehosted melt inclusions. Earth Planet Sci Lett 374:145-155. https://doi.org/10.1016/j.eps1.2013.05.033

Cervelli PF, Miklius A (2003) The shallow magmatic system of Kilauea Volcano. US Geol Surv Prof Pap 1676:149-163

Clague DA, Moore JG, Dixon JE, Friesen WB (1995) Petrology of submarine lavas from Kilauea's Puna Ridge, Hawaii. J Petrol 36:299-349. https://doi.org/10.1093/petrology/36.2.299

Clor LE, Kelly PJ, Nadeau P, Lerner AH, Elias T, Kern C, Werner CA, Diefenbach AK, Cappos M (2018) Gas composition monitoring with Multi-GAS during the 2018 eruption of Kīlauea, Hawai' $i$. AGU Fall Meeting Abstracts:V43J-0271

Danyushevsky LV, Plechov P (2011) Petrolog3: integrated software for modeling crystallization processes. Geochem Geophys Geosyst 12:Q07021. https://doi.org/10.1029/2011GC003516

Delaney PT, McTigue DF (1994) Volume of magma accumulation or withdrawal estimated from surface uplift or subsidence, with application to the 1960 collapse of Kilauea volcano. Bull Volcanol 56:417-424. https://doi.org/10.1007/BF00302823

Desborough GA, Anderson AT, Wright TL (1968) Mineralogy of sulfides from certain Hawaiian basalts. Econ Geol 63:636-644. https://doi.org/10.2113/gsecongeo.63.6.636

Devine JD, Sigurdsson H, Davis AN, Self S (1984) Estimates of sulfur and chlorine yield to the atmosphere from volcanic eruptions and potential climatic effects. J Geophys Res Solid Earth 89:63096325. https://doi.org/10.1029/JB089iB07p06309

Dietterich HR, Diefenbach AK, Soule SA, Zoeller MH, Patrick MP, Major JJ, Lundgren PR (2021) Lava effusion rate evolution and erupted volume during the 2018 Kîlauea lower East Rift Zone eruption. Bull Volcanol 83:25. https://doi.org/10.1007/ s00445-021-01443-6

Dixon JE, Clague DA, Stolper EM (1991) Degassing history of water, sulfur, and carbon in submarine lavas from Kilauea Volcano. Hawaii J Geol 99:371-394. https://doi.org/10.1086/629501

Dixon JE, Stolper EM, Holloway JR (1995) An experimental study of water and carbon dioxide solubilities in mid-ocean ridge basaltic liquids. Part I: calibration and solubility models. J Petrol 36:1607-1631. https://doi.org/10.1093/oxfordjournals.petro logy.a037267

Edmonds M, Sides IR, Swanson DA, Werner C, Martin RS, Mather TA, Herd RA, Jones RL, Mead MI, Sawyer G (2013) Magma storage, transport and degassing during the 2008-10 summit eruption at Kīlauea Volcano, Hawai'i. Geochim Cosmochim Acta 123:284-301. https://doi.org/10.1016/j.gca.2013.05.038

Edmonds M, Mather T, Liu E (2018) A distinct metal fingerprint in arc volcanic emissions. Nat Geosci 11:790-794. https://doi.org/10. 1038/s41561-018-0214-5

Elias T, Sutton AJ (2007) Sulfur dioxide emission rates from Kīlauea Volcano, Hawaii, an update: 2002-2006. U.S. Geological Survey Open-File Report. https://doi.org/10.3133/ofr20071114

Elias T, Sutton AJ (2012) Sulfur dioxide emission rates from Kīlauea Volcano, Hawai ‘i, 2007-2010. U.S. Geological Survey Open-File Report. http://pubs.usgs.gov/of/2012/1107/

Elias T, Kern C, Horton KA, Sutton AJ, Garbeil H (2018a) Measuring $\mathrm{SO}_{2}$ emission rates at Kīlauea Volcano, Hawaii, using an array of upward-looking UV spectrometers, 2014-2017. Front Earth Sci 6:214. https://doi.org/10.3389/feart.2018.00214

Elias T, Kern C, Horton K, Garbeil H, Sutton AJ (2018b) SO $\mathrm{S}_{2}$ emission rates from Kilauea Volcano, Hawaii (2014-2017). U.S. Geological Survey data release. https://doi.org/10.5066/F7794402 
Elias T, Kern C, Sutton AJ, Horton K (2020) Sulfur dioxide emission rates from Kīlauea Volcano, Hawaii, 2008-2013. U.S. Geological Survey data release. https://doi.org/10.5066/P9K0EZII

Ellis W (1825) Narrative of a tour through Hawaii, or, Owhyhee. H. Fisher, Son, and P. Jackson, London. [Simultaneously published in Boston by Crocker \& Brewster. Reprinted in 1826 and 1827 in London by Fisher and Jackson; reprinted 1917 by the Hawaiian Gazette Co., Ltd., Honolulu; reprinted 2004 by Mutual Publishing, Honolulu; 1827 London ed. reprinted in 1963 as Journal of William Ellis by the Advertiser Publishing Co., Ltd., Honolulu]

Epp D, Decker RW, Okamura AT (1983) Relation of summit deformation to east rift zone eruptions on Kilauea Volcano, Hawaii. Geophys Res Lett 10:493-496. https://doi.org/10.1029/GL010 i007p00493

Fiege A, Holtz F, Behrens H, Mandeville CW, Shimizu N, Crede LS, Goettlicher J (2015) Experimental investigation of the $\mathrm{S}$ and $\mathrm{S}$-isotope distribution between $\mathrm{H}_{2} \mathrm{O}-\mathrm{S} \pm \mathrm{Cl}$ fluids and basaltic melts during decompression. Chem Geol 393:36-54. https://doi. org/10.1016/j.chemgeo.2014.11.012

Flinders AF, Caudron C, Johanson IA, Taira T, Shiro B, Haney M (2020) Seismic velocity variations associated with the 2018 lower East Rift Zone eruption of Kîlauea, Hawai' $i$. Bull Volcanol 82:1-13. https://doi.org/10.1007/s00445-020-01380-w

Fortin M-A, Riddle J, Desjardins-Langlais Y, Baker DR (2015) The effect of water on the sulfur concentration at sulfide saturation (SCSS) in natural melts. Geochim Cosmochim Acta 160:100116. https://doi.org/10.1016/j.gca.2015.03.022

Gaetani GA, O’Leary JA, Shimizu N, Bucholz CE, Newville M (2012) Rapid reequilibration of $\mathrm{H}_{2} \mathrm{O}$ and oxygen fugacity in olivinehosted melt inclusions. Geology 40:915-918. https://doi.org/10. 1130/G32992.1

Gansecki C, Lee RL, Shea T, Lundblad SP, Hon K, Parcheta C (2019) The tangled tale of Killauea's 2018 eruption as told by geochemical monitoring. Science 366:eaz0147. https://doi.org/10.1126/ science.aaz0147

Garcia MO, Pietruszka AJ, Rhodes JM (2003) A petrologic perspective of the summit magma chamber of Killauea Volcano, Hawai' ${ }^{i}$. J Petrol 44:2313-2339. https://doi.org/10.1093/petrology/egg079

Gerlach TM (1986) Exsolution of $\mathrm{H}_{2} \mathrm{O}, \mathrm{CO}_{2}$, and $\mathrm{S}$ during eruptive episodes at Kilauea Volcano, Hawaii. J Geophys Res Solid Earth 91:12177-12185. https://doi.org/10.1029/JB091iB12p12177

Gerlach TM, Graeber EJ (1985) Volatile budget of Kilauea Volcano. Nature 313:273-277. https://doi.org/10.1038/313273a0

Gerlach TM, Thomas DM (1986) Carbon and sulphur isotopic composition of Kilauea parental magma. Nature 319:480-483. https:// doi.org/10.1038/319480a0

Gerlach TM, McGee KA, Elias T, Sutton AJ, Doukas MP (2002) Carbon dioxide emission rate of Kīlauea Volcano: implications for primary magma and the summit reservoir. J Geophys Res Solid Earth 107:ECV-3. https://doi.org/10.1029/2001JB000407

Greaney AT, Rudnick RL, Helz RT, Gaschnig RM, Piccoli PM, Ash RD (2017) The behavior of chalcophile elements during magmatic differentiation as observed in Kilauea Iki lava lake, Hawaii. Geochim Cosmochim Acta 210:71-96. https://doi.org/10.1016/j. gca.2017.04.033

Greenland LP, Rose WI, Stokes JB (1985) An estimate of gas emissions and magmatic gas content from Kilauea volcano. Geochim Cosmochim Acta 49:125-129. https://doi.org/10.1016/00167037(85)90196-6

Harris AJ, Dehn J, Calvari S (2007) Lava effusion rate definition and measurement: a review. Bull Volcanol 70:1-22. https://doi.org/ 10.1007/s00445-007-0120-y

Hartley ME, Shorttle O, Maclennan J, Moussallam Y, Edmonds M (2017) Olivine-hosted melt inclusions as an archive of redox heterogeneity in magmatic systems. Earth Planet Sci Lett 479:192205. https://doi.org/10.1016/j.eps1.2017.09.029
Hauri E (2002) SIMS analysis of volatiles in silicate glasses, 2: isotopes and abundances in Hawaiian melt inclusions. Chem Geol 183:115-141. https://doi.org/10.1016/S0009-2541(01)00374-6

Head JW, Wilson L (1987) Lava fountain heights at Pu'u 'O'o, Kilauea, Hawaii: indicators of amount and variations of exsolved magma volatiles. J Geophys Res Solid Earth 92:13715-13719. https:// doi.org/10.1029/JB092iB13p13715

Helz RT, Thornber CR (1987) Geothermometry of Kilauea Iki lava lake, Hawaii. Bull Volcanol 49:651-668. https://doi.org/10.1007/ BF01080357

Helz RT, Wright TL (1992) Differentiation and magma mixing on Kilauea's east rift zone. Bull Volcanol 54:361-384. https://doi. org/10.1007/BF00312319

Helz RT, Clague DA, Mastin LG, Rose TR (2015) Evidence for large compositional ranges in coeval melts erupted from Kīlauea's summit reservoir. In: Hawaiian volcanoes. American Geophysical Union (AGU), pp 125-145. https://doi.org/10.1002/97811 18872079.ch7

Helz RT, Cottrell E, Brounce MN, Kelley KA (2017) Olivine-melt relationships and syneruptive redox variations in the 1959 eruption of Kîlauea Volcano as revealed by XANES. J Volcanol Geotherm Res 333:1-14. https://doi.org/10.1016/j.jvolgeores.2016.12.006

Holcomb RT (1987) Eruptive history and long-term behavior of Kilauea Volcano. In: Decker RW, Wright TL, Stauffer PH (eds) Volcanism in Hawaii. U.S. Geological Survey Professional Paper 1350, pp 261-350. https://pubs.usgs.gov/pp/1987/1350/pdf/chapt ers/pp1350_ch12.pdf. Accessed 05/04/2020

Hsieh PA, Ingebritsen SE (2019) Groundwater inflow toward a preheated volcanic conduit: application to the 2018 eruption at Kīlauea Volcano, Hawai'i. J Geophys Res Solid Earth 124:14981506. https://doi.org/10.1029/2018JB017133

Iacono-Marziano G, Morizet Y, Le Trong E, Gaillard F (2012) New experimental data and semi-empirical parameterization of $\mathrm{H}_{2} \mathrm{O}-$ $\mathrm{CO}_{2}$ solubility in mafic melts. Geochim Cosmochim Acta 97:123. https://doi.org/10.1016/j.gca.2012.08.035

Ingebritsen SE, Flinders AF, Kauahikaua JP, Hsieh PA (2021) Modeling groundwater inflow to the new crater lake at Kîlauea Volcano, Hawai'i. Groundwater 59:7-15. https://doi.org/10.1111/ gwat. 13023

Jugo PJ, Wilke M, Botcharnikov RE (2010) Sulfur K-edge XANES analysis of natural and synthetic basaltic glasses: implications for S speciation and $\mathrm{S}$ content as function of oxygen fugacity. Geochim Cosmochim Acta 74:5926-5938. https://doi.org/10. 1016/j.gca.2010.07.022

Kelly P, Nadeau P, Elias T, Clor L, Diefenbach A, Younger E, Kamibayashi K, Lerner A, Kern C, Werner C (2021) Monitoring gas compositions during recent eruptions of Kīlauea Volcano with unoccupied aircraft systems. 1st IAVCEI-CCVG Virtual Workshop Abstracts

Kern C, Lerner AH, Elias T, Nadeau PA, Holland L, Kelly PJ, Werner CA, Clor LE, Cappos M (2020) Quantifying gas emissions associated with the 2018 rift eruption of Kīlauea Volcano using ground-based DOAS measurements. Bull Volcanol 82:55. https:// doi.org/10.1007/s00445-020-01390-8

Labidi J, Cartigny P (2016) Negligible sulfur isotope fractionation during partial melting: evidence from Garrett transform fault basalts, implications for the late-veneer and the hadean matte. Earth Planet Sci Lett 451:196-207. https://doi.org/10.1016/j. eps1.2016.07.012

Lee RL, Gansecki C, Lundblad S, Mills P, Adams DT, Conrey R, Wagoner L (2019) Whole-rock and glass chemistry of lava samples collected during the 2018 Lower East Rift Zone eruption of Kilauea. U.S. Geological Survey data release. https://doi.org/ 10.5066/P9LVY7GV

Lerner AH (2020) The depths and locations of magma reservoirs and their consequences for the behavior of sulfur and volcanic 
degassing. Ph.D. Thesis, University of Oregon. ProQuest Dissertations Publishing 28022240. https://search.proquest.com/openv iew/cec1ff16af338dce2495b5a1a491aa88/1?pq-origsite=gscho lar\&cbl=44156. Accessed 01/29/2021

Lesher CE, Spera FJ (2015) Thermodynamic and transport properties of silicate melts and magma. In: Sigurdsson H (ed) The encyclopedia of volcanoes, 2nd edn. Academic Press, Amsterdam, pp 113-141. https://doi.org/10.1016/B978-0-12-385938-9.00005-5

Longpré M-A, Stix J, Klügel A, Shimizu N (2017) Mantle to surface degassing of carbon- and sulphur-rich alkaline magma at El Hierro, Canary Islands. Earth Planet Sci Lett 460:268-280. https://doi.org/10.1016/j.epsl.2016.11.043

Lynn KJ, Garcia MO, Shea T, Costa F, Swanson DA (2017) Timescales of mixing and storage for Keanakāko 'i Tephra magmas (1500-1820 C.E.), Kīlauea Volcano, Hawai'i. Contrib Mineral Petrol 172:76. https://doi.org/10.1007/s00410-017-1395-4

Marini L, Moretti R, Accornero M (2011) Sulfur isotopes in magmatic-hydrothermal systems, melts, and magmas. Rev Mineral Geochem 73:423-492. https://doi.org/10.2138/rmg.2011.73.14

Miyoshi T, Sakai H, Chiba H (1984) Experimental study of sulfur isotope fractionation factors between sulfate and sulfide in high temperature melts. Geochem J 18:75-84. https://doi.org/10.2343/geochemj.18.75

Montgomery-Brown EK, Johanson IA, Poland MP, Lundgren P (2020) The lower East Rift Zone intrusion at Kīlauea Volcano, 2018 from GPS, InSAR and tilt. AGU Fall Meeting Abstracts:V002-0014

Moore RB, Helz RT, Dzurisin D, Eaton GP, Koyanagi RY, Lipman PW, Lockwood JP, Puniwai GS (1980) The 1977 eruption of Kilauea volcano, Hawaii. J Volcanol Geotherm Res 7:189-210. https:// doi.org/10.1016/0377-0273(80)90029-3

Moore LR, Gazel E, Tuohy R, Lloyd AS, Esposito R, Steele-MacInnis M, Hauri EH, Wallace PJ, Plank T, Bodnar RJ (2015) Bubbles matter: an assessment of the contribution of vapor bubbles to melt inclusion volatile budgets. Am Mineral 100:806-823. https://doi.org/10.2138/am-2015-5036

Mourey A, Shea T, Costa F, Shiro B, Lee RL, Gansecki CA, Oalmann J (2019) Diffusion timescales in olivine from the 2018 eruption at Kilauea Volcano reveal syn-eruptive (months) and long term (years) magma mixing processes. AGU Fall Meeting Abstracts: V43C-0208

Moussallam Y, Edmonds M, Scaillet B, Peters N, Gennaro E, Sides I, Oppenheimer C (2016) The impact of degassing on the oxidation state of basaltic magmas: a case study of Kīlauea volcano. Earth Planet Sci Lett 450:317-325. https://doi.org/10.1016/j.epsl. 2016.06.031

Nadeau PA, Diefenbach AK, Hurwitz S, Swanson DA (2020) From lava to water: a new era at Kīlauea. Eos 101. https://doi.org/10. 1029/2020EO149557

Neal CA, Brantley SR, Antolik L, Babb JL, Burgess M, Calles K, Cappos M, Chang JC, Conway S, Desmither L, Dotray P, Elias T, Fukunaga P, Fuke S, Johanson IA, Kamibayashi K, Kauahikaua J, Lee RL, Pekalib S, Miklius A, Million W, Moniz CJ, Nadeau PA, Okubo P, Parcheta C, Patrick MR, Shiro B, Swanson DA, Tollett W, Trusdell F, Younger EF, Zoeller MH, Montgomery-Brown EK, Anderson KR, Poland MP, Ball JL, Bard J, Coombs M, Dietterich HR, Kern C, Thelen WA, Cervelli PF, Orr T, Houghton BF, Gansecki C, Hazlett R, Lundgren P, Diefenbach AK, Lerner AH, Waite G, Kelly P, Clor L, Werner C, Mulliken K, Fisher G, Damby D (2019) The 2018 rift eruption and summit collapse of Kīlauea Volcano. Science 363:367-374. https://doi.org/10.1126/science.aav7046

Orr TR, Poland MP, Patrick MR, Thelen WA, Sutton AJ, Elias T, Thornber CR, Parcheta C, Wooten KM (2015) Kîlauea's 5-9 March 2011 Kamoamoa fissure eruption and its relation to 30+ years of activity from Pu'u 'Ō'ō: chapter 18 . Geophys Monogr 208:393-420. https://doi.org/10.1002/9781118872079.ch18
Patrick MR, Anderson KR, Poland MP, Orr TR, Swanson DA (2015) Lava lake level as a gauge of magma reservoir pressure and eruptive hazard. Geology 43:831-834. https://doi.org/10.1130/ G36896.1

Patrick MR, Swanson D, Orr T (2019a) A review of controls on lava lake level: insights from Halema 'uma 'u Crater. Kīlauea Volcano Bull Volcanol 81:13. https://doi.org/10.1007/s00445-019-1268-y

Patrick MR, Orr T, Anderson K, Swanson D (2019b) Eruptions in sync: improved constraints on Kîlauea Volcano's hydraulic connection. Earth Planet Sci Lett 507:50-61. https://doi.org/10.1016/j.eps1. 2018.11.030

Patrick MR, Dietterich HR, Lyons JJ, Diefenbach AK, Parcheta C, Anderson KR, Namiki A, Sumita I, Shiro B, Kauahikaua JP (2019c) Cyclic lava effusion during the 2018 eruption of Kīlauea Volcano. Science 366:eaay9070. https://doi.org/10.1126/science. aay 9070

Patrick MR, Johanson I, Shea T, Waite G (2020a) The historic events at Kîlauea Volcano in 2018: summit collapse, rift zone eruption, and $\mathrm{M}_{\mathrm{w}} 6.9$ earthquake: preface to the special issue. Bull Volcanol 82:46. https://doi.org/10.1007/s00445-020-01377-5

Patrick MR, Houghton BF, Anderson KR, Poland MP, MontgomeryBrown E, Johanson I, Thelen W, Elias T (2020b) The cascading origin of the 2018 Kîlauea eruption and implications for future forecasting. Nat Commun 11:5646. https://doi.org/10.1038/ s41467-020-19190-1

Patrick MR, Orr TR, Swanson Don, Houghton BF, Wooten KM, Desmither L, Parcheta C, Fee D (2021) Kīlauea's 2008-2018 summit lava lake - chronology and eruption insights. In: Patrick MR, Orr T, Swanson D, Houghton BF (eds) The 2008-2018 Summit Lava Lake at Kīlauea Volcano, Hawai' i. U.S. Geological Survey Professional Paper 1867, p 50. https://doi.org/10.3133/ pp1867A

Pietruszka AJ, Heaton DE, Marske JP, Garcia MO (2015) Two magma bodies beneath the summit of Kîlauea Volcano unveiled by isotopically distinct melt deliveries from the mantle. Earth Planet Sci Lett 413:90-100. https://doi.org/10.1016/j.eps1.2014. 12.040

Pietruszka AJ, Marske JP, Heaton DE, Garcia MO, Rhodes JM (2018) An isotopic perspective into the magmatic evolution and architecture of the rift zones of Kîlauea Volcano. J Petrol 59:23112352. https://doi.org/10.1093/petrology/egy098

Poland MP, Miklius A, Montgomery-Brown EK (2014) Magma supply, storage, and transport at shield-stage Hawaiian volcanoes. In: Poland MP, Takahashi TJ, Landowski CM (eds) Characteristics of Hawaiian volcanoes. U.S. Geological Survey Professional Paper 1801, pp 179-234. https://doi.org/10.3133/ pp 18015

Poland MP, de Zeeuw-van DE, Bagnardi M, Johanson IA (2019) Postcollapse gravity increase at the summit of Kîlauea Volcano, Hawai'i. Geophys Res Lett 46:14430-14439. https://doi.org/10. 1029/2019GL084901

Portnyagin M, Almeev R, Matveev S, Holtz F (2008) Experimental evidence for rapid water exchange between melt inclusions in olivine and host magma. Earth Planet Sci Lett 272:541-552. https://doi.org/10.1016/j.epsl.2008.05.020

Richet P, Bottinga Y, Javoy M (1977) A review of hydrogen, carbon, nitrogen, oxygen, sulphur, and chlorine stable isotope fractionation among gaseous molecules. Annu Rev Earth Planet Sci 5:65-110. https://doi.org/10.1146/annurev.ea.05.050177.000433

Richter DH, Eaton JP, Murata KJ, Ault WU, Krivoy HL (1970) Chronological narrative of the 1959-60 eruption of Kilauea volcano, Hawaii. U.S. Geological Survey Professional Paper 537-D. https://doi.org/10.3133/pp537E

Riker J (2005) The 1859 eruption of Mauna Loa Volcano, Hawai'i: controls on the development of long lava channels. MSc Thesis, University of Oregon 
Rose WI (1977) Scavenging of volcanic aerosol by ash: atmospheric and volcanologic implications. Geology 5:621-624. https://doi. org/10.1130/0091-7613(1977)5\%3c621:SOVABA\%3e2.0.CO;2

Rowe MC, Thornber CR, Orr TR (2015) Primitive components, crustal assimilation, and magmatic degassing during the early 2008 Kīlauea summit eruptive activity. In: Carey R, Cayol V, Poland MP (eds) Hawaiian volcanoes: from source to surface. AGU Geophysical Monograph Series, pp 439-455. https://doi.org/10.1002/ 9781118872079.ch20

Ryan MP (1987) Elasticity and contractancy of Hawaiian olivine tholeiite and its role in the stability and structural evolution of subcaldera magma reservoirs and rift systems. In: Decker RW, Wright TL, Stauffer PH (eds) Volcanism in Hawaii. U.S. Geological Survey Professional Paper 1350, pp 1395-1447. https:// pubs.usgs.gov/pp/1987/1350/pdf/chapters/pp1350_ch52.pdf. Accessed 05/04/2020

Sakai H, Casadevall TJ, Moore JG (1982) Chemistry and isotope ratios of sulfur in basalts and volcanic gases at Kilauea Volcano, Hawaii. Geochim Cosmochim Acta 46:729-738. https://doi.org/ 10.1016/0016-7037(82)90024-2

Sharma K, Blake S, Self S, Krueger AJ (2004) $\mathrm{SO}_{2}$ emissions from basaltic eruptions, and the excess sulfur issue. Geophys Res Lett 31:L13612. https://doi.org/10.1029/2004GL019688

Shiro BR, Zoeller MH, Kamibayashi K, Johanson IA, Parcheta C, Patrick MR, Nadeau P, Lee L, Miklius A (2021) Monitoring network changes during the 2018 Killauea Volcano eruption. Seismol Res Lett 92:102-118. https://doi.org/10.1785/0220200284

Sides IR, Edmonds M, Maclennan J, Swanson DA, Houghton BF (2014a) Eruption style at Kīlauea Volcano in Hawai' $i$ linked to primary melt composition. Nat Geosci 7:464-469. https://doi. org/10.1038/ngeo2140

Sides I, Edmonds M, Maclennan J, Houghton BF, Swanson DA, SteeleMacInnis MJ (2014b) Magma mixing and high fountaining during the 1959 Kīlauea Iki eruption, Hawai' $i$. Earth Planet Sci Lett 400:102-112. https://doi.org/10.1016/j.epsl.2014.05.024

Smythe DJ, Wood BJ, Kiseeva ES (2017) The S content of silicate melts at sulfide saturation: new experiments and a model incorporating the effects of sulfide composition. Am Mineral 102:795-803. https://doi.org/10.2138/am-2017-5800CCBY

Soule SA, Zoeller M, Parcheta C (2021) Submarine lava deltas of the 2018 eruption of Kīlauea volcano. Bull Volcanol 83:23. https:// doi.org/10.1007/s00445-020-01424-1

Sparks RSJ (1978) The dynamics of bubble formation and growth in magmas: a review and analysis. J Volcanol Geotherm Res 3:137. https://doi.org/10.1016/0377-0273(78)90002-1

Stone WE, Fleet ME (1991) Nickel-copper sulfides from the 1959 eruption of Kilauea Volcano, Hawaii: contrasting compositions and phase relations in eruption pumice and Kilauea Iki lava lake. Am Mineral 76:1363-1372. https://pubs.geoscienceworld.org/msa/ ammin/article-abstract/76/7-8/1363/42586/. Accessed 05/04/2020

Sutton AJ, Elias T (2014) One hundred volatile years of volcanic gas studies at the Hawaiian Volcano Observatory. In: Poland MP, Takahashi TJ, Landowski CM (eds) Characteristics of Hawaiian volcanoes. U.S. Geological Survey Professional Paper 1801, pp 179-234. https://pubs.usgs.gov/pp/1801/downloads/pp1801_ Chap7_Sutton.pdf. Accessed 01/17/2021

Sutton AJ, Elias T, Kauahikaua J (2003) Lava-effusion rates for the Pu'u ' $\overline{\mathrm{O}}$ ' $\mathrm{o}-$ Kūpaianaha eruption derived from $\mathrm{SO}_{2}$ emissions and very low frequency (VLF) measurements. In: Heliker C, Swanson DA, Takahashi TJ (eds) Pu'u 'Ō'ō-Kūpaianaha eruption of Kilauea Volcano, Hawai'i: the first 20 years. U.S. Geological Survey Professional Paper 1676, pp 137-148. https://doi.org/10.3133/pp18017

Swanson DA, Duffield WA, Jackson DB, Peterson DW (1979) Chronological narrative of the 1969-71 Mauna Ulu eruption of Kilauea Volcano, Hawaii. U.S. Geological Survey Professional Paper 1056. https://doi.org/10.3133/pp1056
Swanson DA, Rose TR, Mucek AE, Garcia MO, Fiske RS, Mastin LG (2014) Cycles of explosive and effusive eruptions at Kīlauea Volcano, Hawai'i. Geology 42:631-634. https://doi.org/10.1130/ G35701.1

Symonds RB, Gerlach TM, Reed MH (2001) Magmatic gas scrubbing: implications for volcano monitoring. J Volcanol Geotherm Res 108:303-341. https://doi.org/10.1016/S0377-0273(00)00292-4

Tang Y, Tong DQ, Yang K, Lee P, Baker B, Crawford A, Luke W, Stein A, Campbell PC, Ring A, Flynn J, Wang Y, McQueen J, Pan L, Huang J, Stajner I (2020) Air quality impacts of the 2018 Mt. Kilauea Volcano eruption in Hawaii: a regional chemical transport model study with satellite-constrained emissions. Atmos Environ 237:117648. https://doi.org/10.1016/j.atmosenv.2020. 117648

Thomson A, Maclennan J (2013) The distribution of olivine compositions in Icelandic basalts and picrites. J Petrol 54:745-768. https://doi.org/10.1093/petrology/egs083

Thordarson T, Self S, Oskarsson N, Hulsebosch T (1996) Sulfur, chlorine, and fluorine degassing and atmospheric loading by the 1783-1784 AD Laki (Skaftár Fires) eruption in Iceland. Bull Volcanol 58:205-225. https://doi.org/10.1007/s004450050136

Thornber CR, Orr TR, Heliker C, Hoblitt RP (2015) Petrologic testament to changes in shallow magma storage and transport during $30+$ years of recharge and eruption at Kīlauea Volcano, Hawai ' $i$. In: Carey R, Cayol V, Poland MP (eds) Hawaiian volcanoes: from source to surface. AGU Geophysical Monograph Series, pp 147-188. https://doi.org/10.1002/9781118872079.ch8

Tucker JM, Hauri EH, Pietruszka AJ, Garcia MO, Marske JP, Trusdell FA (2019) A high carbon content of the Hawaiian mantle from olivine-hosted melt inclusions. Geochim Cosmochim Acta 254:156-172. https://doi.org/10.1016/j.gca.2019.04.001

Tuohy RM, Wallace PJ, Loewen MW, Swanson DA, Kent AJ (2016) Magma transport and olivine crystallization depths in Kīlauea's east rift zone inferred from experimentally rehomogenized melt inclusions. Geochim Cosmochim Acta 185:232-250. https://doi. org/10.1016/j.gca.2016.04.020

USGS-HVO (2020a) Photo and Video Chronology - Kīlauea - December 20, 2020. U.S. Geological Survey Hawaiian Volcano Observatory. https://www.usgs.gov/center-news/photo-and-videochronology-k-lauea-december-20-2020. Accessed 02/23/2021

USGS-HVO (2020b) Photo and Video Chronology - Kīlauea - December 26, 2020. U.S. Geological Survey Hawaiian Volcano Observatory. https://www.usgs.gov/center-news/photo-and-videochronology-k-lauea-december-26-2020. Accessed 02/23/2021

Vinet N, Higgins MD (2011) What can crystal size distributions and olivine compositions tell us about magma solidification processes inside Kilauea Iki lava lake, Hawaii? J Volcanol Geotherm Res 208:136-162. https://doi.org/10.1016/j.jvolgeores.2011.09.006

Wallace PJ (2018) Depths of crystallization and magma storage beneath Kilauea and Mauna Loa based on $\mathrm{CO}_{2}$ in melt inclusions. Goldschmidt Abstracts, Boston, MA

Wallace PJ, Carmichael ISE (1992) Sulfur in basaltic magmas. Geochim Cosmochim Acta 56:1863-1874. https://doi.org/10.1016/ 0016-7037(92)90316-B

Wallace PJ, Anderson AT (1998) Effects of eruption and lava drainback on the $\mathrm{H}_{2} \mathrm{O}$ contents of basaltic magmas at Kilauea Volcano. Bull Volcanol 59:327-344. https://doi.org/10.1007/s004450050195

Whitty R, Ilyinskaya E, Mason E, Wieser P, Liu E, Schmidt A, Roberts T, Pfeffer M, Brooks B, Mather T (2020) Spatial and temporal variations in $\mathrm{SO}_{2}$ and $\mathrm{PM}_{25}$ levels from 2007-2018 Kîlauea Volcano, Hawai' ${ }^{i}$. Front Earth Sci. https://doi.org/10.3389/feart. 2020.00036

Wieser PE, Edmonds M, Maclennan J, Jenner FE, Kunz BE (2019) Crystal scavenging from mush piles recorded by melt inclusions. Nat Commun 10:1-11. https://doi.org/10.1038/ s41467-019-13518-2 
Wieser PE, Jenner FE, Edmonds M, Maclennan J, Kunz BE (2020) Chalcophile elements track the fate of sulfur at Kilauea Volcano, Hawai'i. Geochim Cosmochim Acta 282:245-275. https://doi. org/10.1016/j.gca.2020.05.018

Wieser PE, Lamadrid H, Maclennan J, Edmonds M, Matthews S, Iacovino K, Jenner FE, Gansecki C, Trusdell F, Lee RL, Ilyinskaya E (2021) Reconstructing magma storage depths for the 2018 Kîlauean eruption from melt inclusion $\mathrm{CO}_{2}$ contents: the importance of vapor bubbles. Geochem Geophys Geosystems 22:e2020GC009364. https://doi.org/10.1029/ 2020GC009364

Wilson L, Parfitt EA, Head JW (1995) Explosive volcanic eruptionsVIII. The role of magma recycling in controlling the behaviour of Hawaiian-style lava fountains. Geophys J Int 121:215-225. https://doi.org/10.1111/j.1365-246X.1995.tb03522.x
Wolfe EW, Garcia MO, Jackson DB, Koyanagi RY, Neal CA, Okamura, AT (1987) The Puu Oo eruption of Kilauea Volcano, Hawaii: episodes 1 through 20, January 3, 1983, through June 8, 1984. In: Decker RW, Wright TL, Stauffer PH (eds) Volcanism in Hawaii. U.S. Geological Survey Professional Paper 1350, pp 471-508. https://pubs.usgs.gov/pp/1987/1350/pdf/chapters/ pp1350_ch17.pdf. Accessed 05/04/2020

Wright TL, Klein FW (eds) (2014) Two hundred years of magma transport and storage at Kīlauea Volcano, Hawai 'i, 1790-2008. U.S. Geological Survey Professional Paper 1806. https://doi.org/10.3133/pp1806

Zoeller MH, Perroy RL, Wessels RL, Fisher GB, Robinson JE, Bard JA, Peters J, Mosbrucker AR, Parcheta CE (2020) Geospatial database of the 2018 lower East Rift Zone eruption of Kîlauea Volcano, Hawai'i. U.S. Geological Survey data release. https:// doi.org/10.5066/P9S7UQKQ 